\title{
Towards optimal caesarean practice
}

Citation for published version (APA):

Melman, S. (2020). Towards optimal caesarean practice. [Doctoral Thesis, Maastricht University]. Gildeprint Drukkerijen. https://doi.org/10.26481/dis.20201014sm

Document status and date:

Published: 01/01/2020

DOI:

10.26481/dis.20201014sm

Document Version:

Publisher's PDF, also known as Version of record

\section{Please check the document version of this publication:}

- A submitted manuscript is the version of the article upon submission and before peer-review. There can be important differences between the submitted version and the official published version of record.

People interested in the research are advised to contact the author for the final version of the publication, or visit the DOI to the publisher's website.

- The final author version and the galley proof are versions of the publication after peer review.

- The final published version features the final layout of the paper including the volume, issue and page numbers.

Link to publication

\footnotetext{
General rights rights.

- You may freely distribute the URL identifying the publication in the public portal. please follow below link for the End User Agreement:

www.umlib.nl/taverne-license

Take down policy

If you believe that this document breaches copyright please contact us at:

repository@maastrichtuniversity.nl

providing details and we will investigate your claim.
}

Copyright and moral rights for the publications made accessible in the public portal are retained by the authors and/or other copyright owners and it is a condition of accessing publications that users recognise and abide by the legal requirements associated with these

- Users may download and print one copy of any publication from the public portal for the purpose of private study or research.

- You may not further distribute the material or use it for any profit-making activity or commercial gain

If the publication is distributed under the terms of Article $25 \mathrm{fa}$ of the Dutch Copyright Act, indicated by the "Taverne" license above, 


\section{TOWARDS \\ OPTIMAL CAESAREAN}

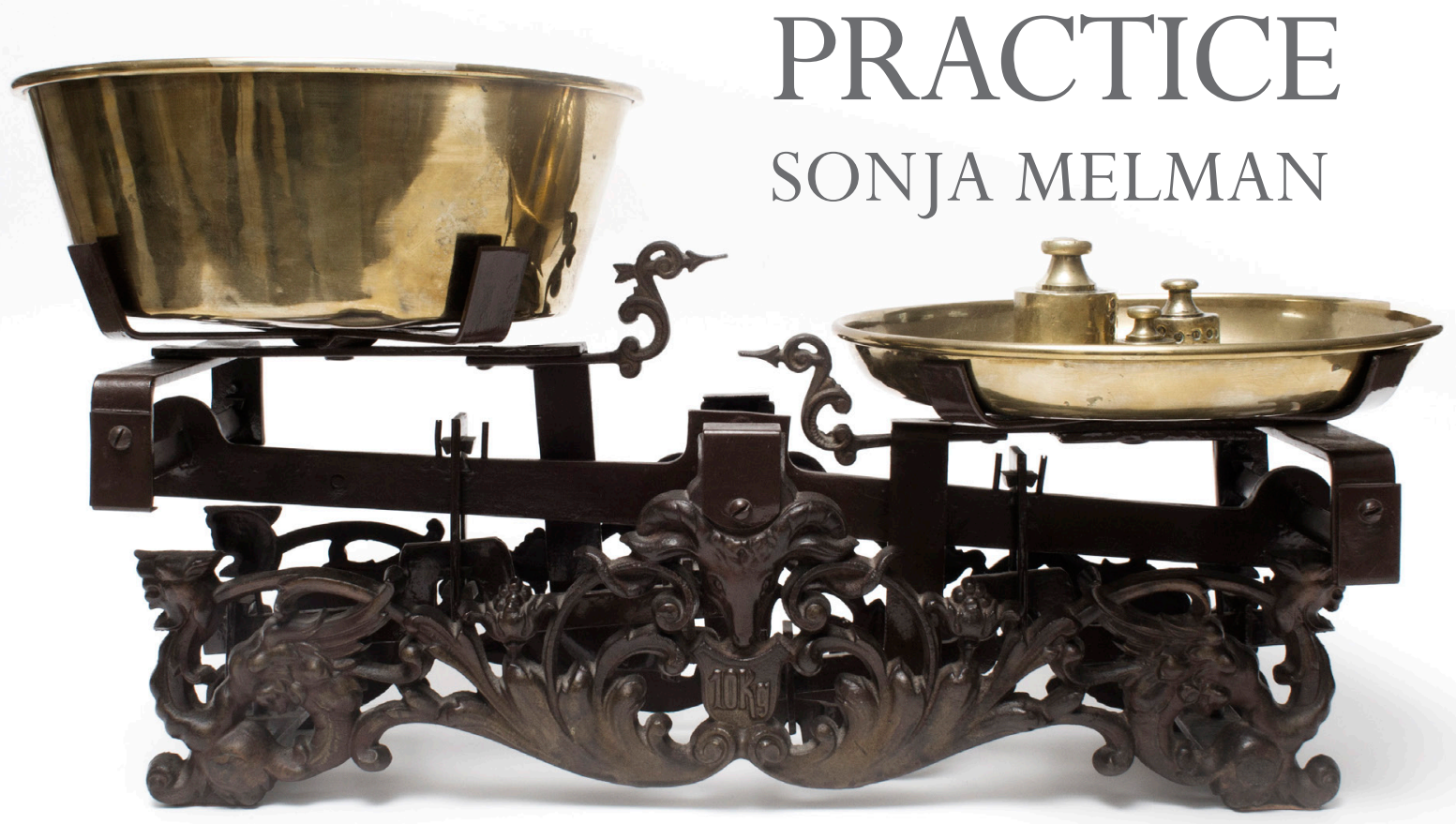





\section{Towards optimal caesarean practice}


This study has been performed by the Department of Obstetrics and Gynaecology of Maastricht University Medical Centre, Maastricht and IQ Scientific Institute for Quality of Healthcare, University Medical Centre St. Radboud, Nijmegen.

This study was funded by the Netherlands Organisation for Health Research and Development (zonMW grant No 17100.3006) and the collaboration of the Dutch Perinatal Research Consortium.

Graphic design: Jean Scheijen

Author: Sonja Melman

Lay-out: Ilse Modder | www.ilsemodder.nl

Printed by: Gildeprint Enschede | www.gildeprint.nl

ISBN: 978-94-6419-041-0

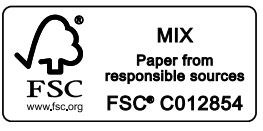

All rights reserved. No part of this thesis may be reproduced or transmitted in any form or by any means, without prior permission of the author. 


\title{
Towards optimal caesarean practice
}

\author{
PROEFSCHRIFT
}

ter verkrijging van de graad Doctor

aan de Universiteit Maastricht,

op gezag van de rector magnificus Prof. dr. Rianne. M. Letschert, volgens het besluit van het College van Decanen,

in het openbaar te verdedigen op

woensdag 14 oktober 2020 om 14:00 uur

door

Sonja Melman 


\section{Promotor}

Prof. Dr. J.G. Nijhuis

\section{Copromotoren}

Dr. H.C.J. Scheepers

Dr. R.P.M.G. Hermens, IQ Healthcare, Radboud Universitair Medisch Centrum

\section{Beoordelingscommissie}

Prof. dr. N.D. Bouvy, voorzitter

Prof. dr. K. Bloemenkamp, Universitair Medisch Centrum Utrecht

Dr. J. Braspenning, IQ Healthcare, Radboud Universitair Medisch Centrum

Prof. dr. M.E.A. Spaanderman

Prof. dr. L.J.I. Zimmermann 


\section{CONTENTS}

Chapter 1: $\quad$ General introduction

Chapter 2: $\quad$ SIMPLE: an implementation study on the recommendations

from international evidence-based guidelines on caesarean sections in the Netherlands.

Chapter 3: Development and measurement of guidelines-based quality indicators of caesarean section care in the Netherlands:

a RAND-modified Delphi procedure and retrospective medical chart review.

Chapter 4: Identification of barriers and facilitators for optimal cesarean section care: perspective of professionals.

Chapter 5: Changing the evaluation of caesarean section care:

combining the Robson Ten-Group Classification System

with valid quality indicators.

Chapter 6: $\quad$ Predicting successful intended vaginal delivery after

previous caesarean section: external validation of two predictive models in a Dutch nationwide registration-based cohort with a high intended vaginal delivery rate.

Chapter 7: $\quad$ Summary and general discussion

Chapter 8: $\quad$ Valorisatie

Chapter 9: $\quad$ Nederlandstalige samenvatting

Chapter 10: $\quad$ Publications and Presentations

Dankwoord

Curriculum Vitae 

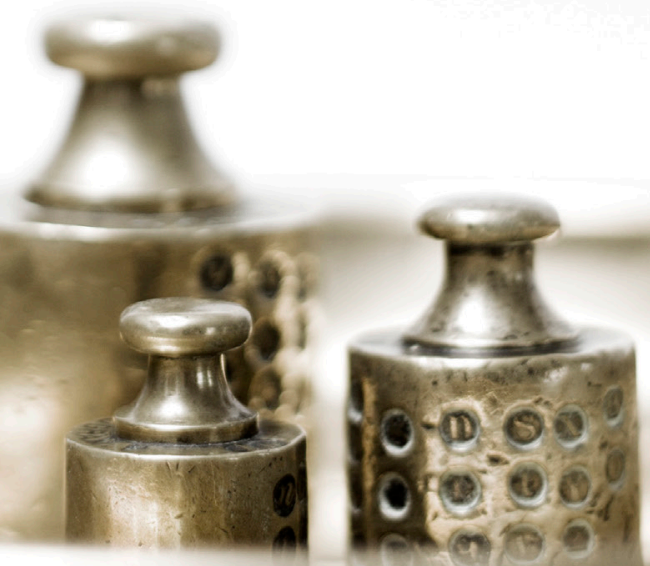
General introduction and aim of this thesis 


\section{General introduction and aim of this thesis}

This thesis focuses on studies to improve the Dutch practice of caesarean sections (CS), with valid quality indicators as a basis. This introduction starts with a brief history of CS, after which we will discuss both the short-term and the long-term consequences of this operation. Next, the unplanned (emergency) CS and vaginal birth after CS (VBAC) will be discussed. This chapter concludes with the outline of this thesis.

\section{History of CS}

Originally, the CS was an operation performed on a dead or dying mother, probably because of religious beliefs, since mother and child had to be buried separately. Although it is commonly believed to be derived from the surgical birth of Julius Caesar in July 100 BC, this seems highly unlikely because his mother Aurelia survived the procedure and she is known to have been aware of her son's invasion of Britain in 55 BC [1].

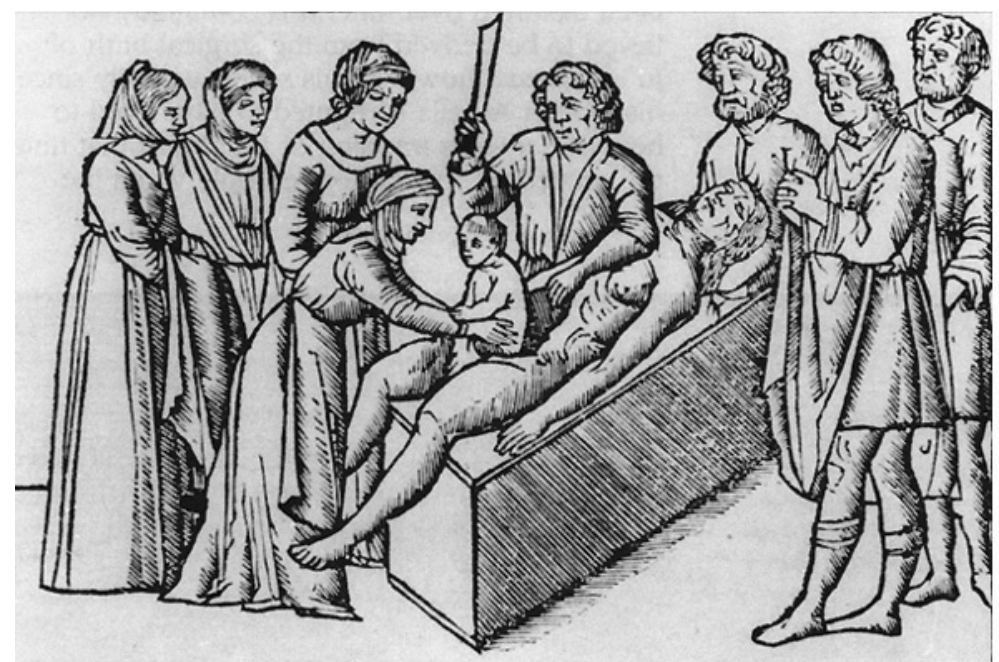

The birth of Julius Caesar. From Suetonius' Lives of the Twelve Caesars, 1506 woodcut.

The first written record of a surviving mother and baby is from Switzerland in 1500, where Jacob Nufer performed a CS on his wife. After several days in labour, and despite the help of 13 midwives, Jacob got permission from the local authorities to perform the operation. The mother survived and had 5 vaginal births thereafter. However, historians question the accuracy of this story, since it was recorded 82 years later. Thus, the precise date of the first CS is not certain. 
Although many cultures refer to a CS for non-progressing labour in pelvic anomalies or abnormal foetal presentation, it was an unsafe procedure due to lack of knowledge of anatomy, lack of anaesthesia and risks of major bleeding and infection.

\section{CS rates}

In the Netherlands in 1900, $1.8 \%$ of all deliveries took place in hospital. A CS was performed in $0.7 \%$ of delivering women, with a maternal and neonatal mortality rate of $12 \%$ and $2 \%$, respectively [1]. A lot has changed since those days. We are now faced with a worldwide rise in caesarean section (CS) rates. Although the Netherlands has a relatively low CS rate (16.7\%) compared to the United Kingdom (24.6\%) and the United States (32\%), the most impressive rise in CS rate is found in 'low risk pregnancies': healthy women with a singleton in cephalic position at term [2-5]. The World Health Organization estimates a CS rate between 10-15\% to be optimal [6]. Despite this suggested optimal CS rate, the Euro-Peristat study showed CS percentages in Europe ranging from 14.8 to 52.2\%, without evidence of improved foetal outcome with increasing CS rate (Figure 1) [7].

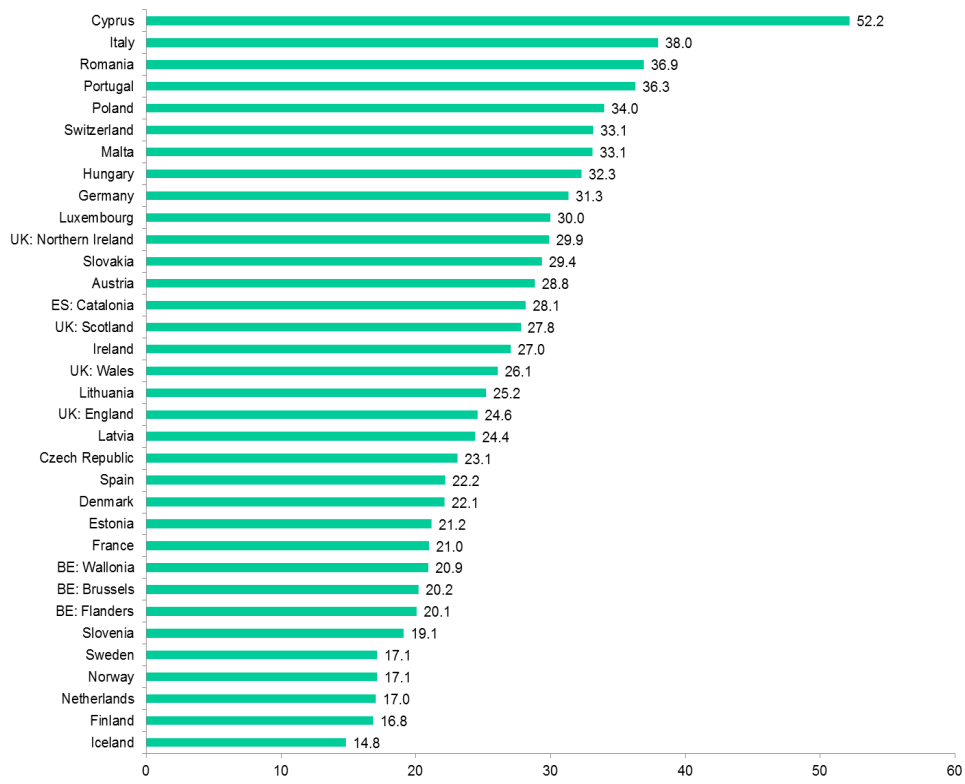

Figure 1: European CS rate, Europeristat Group [7]

Nowadays a CS is considered to be a relatively safe procedure, but it is still associated with increased short-term morbidity and mortality, with an increased risk of abnormal placentation, and uterine rupture in future pregnancies [8,9]. Furthermore, rising CS rates 
are not associated with improved outcome for mother and neonate [10-12]. A CS costs twice as much as a vaginal delivery, 1256 euros to 9652 euros extra depending on the country of origin [13]. Adding all costs of future morbidity and the increased risk of future repeat CS, the estimated additional costs of one CS are 7500 euros.

Previous studies mostly focused on epidemiological data such as rising maternal age, maternal request for CS, and the decline in attempt of VBAC [14,15]. Applying the Robson Ten-Group Classification System, others mainly identified the nulliparous single cephalic term pregnancy, as well as the women with a previous CS to be the most important contributors to the total CS rate $[16,18]$. Prevention of unnecessary, unplanned CS in nulliparous women will have an effect on both current and future pregnancies. Therefore, more insight is needed in factors influencing the unplanned CS rates in this group of women.

\section{Quality of care}

Through the years several international obstetrical organizations developed evidence-based guidelines with recommendations for optimal care regarding the decision when to perform a CS. However, the crucial issue remains whether these recommendations are actually followed. In order to improve current CS practice, it is of importance to gain insight into the extent of guideline implementation in daily practice and the factors that improve or hinder guideline implementation. Before this can be measured, valid quality indicators for optimal care have to be systematically developed $[19,20]$. The model of Grol et al., describes the steps necessary to develop, test and evaluate a strategy to implement guidelines. These steps for CS practice are specified below.

\section{Step 1. Description of evidence based recommendations on CS practice}

Quality indicators can be used to asses CS practice. Lawrence et al. defined quality indicators as 'measurable elements of practice performance for which there is evidence or consensus that they can be used to assess the quality, and hence change in the quality, of care provided' [21]. Recommendations on CS practice from national and international guidelines and literature will be evaluated by an expert panel consisting of obstetricians and midwives.

\section{Step 2. Assessment of actual CS practice}

Vankan et al. showed that in 21 Dutch hospitals elective repeat CS rates varied between 7 and $51 \%$. Vaginal birth after CS rates ranged from 53 to $90 \%$. More than $85 \%$ of practice variation could not be explained by risk factors at patient level. A lack of guideline adherence might play a role in this practice variation. The developed quality indicators on CS practice 
will be used to gain insight into current CS practice in 21 Dutch hospitals.

\section{Step 3. Identification of barriers and facilitators}

Besides insight into quality indicators and current CS practice, insight into facilitators and barriers among all professionals involved in CS decision-making is essential. This insight can support the development of a tailored strategy to overcome barriers and improve guideline implementation. Barriers and facilitators for CS practice will be explored among midwives, obstetrical residents and obstetricians at different domains described by Grol: features of guideline recommendations, professionals and patients, as well as the social, organizational and financial context [22].

\section{Step 4-5. Improving CS practice}

Insight into current CS practice and into the hindering and facilitating factors influencing obstetrical policy on CS is essential to improve CS practice. It will allow definition of groups of women where a tailor-made implementation strategy will most likely be meaningful and cost effective, without negatively affecting the outcome for mother and child.

Measures that influence the CS rate are directed at 1) planned CS with a questionable indication for CS, 2) counselling of women when a CS and a vaginal delivery are both more or less equal options and 3) prevention of unplanned CS when a vaginal delivery is the normal policy. At this moment, it is unclear which situations are most urgent to tackle. The aim is to first identify women with clinical situations that occur regularly (e.g. discussing the role of a CS in triplets will not reduce the total amount of unnecessary CS), and/or in whom current care deviates substantially from the optimal care. Secondly, when a group of women is identified in whom a discrepancy exists between current care and optimal care and in whom barriers for optimal care are identified, an intervention strategy can be developed. For example: in cases with a breech presentation, most guidelines advise an external version. A possible finding could be that the CS rate for breech presentation is far too high because an external version is not (adequately) performed. Training and education of inexperienced caregivers can then be a useful strategy. In order to improve CS care, we will identify those women with situations that occur regularly and also have a low adherence rate.

\section{Aim of this thesis}

This thesis focuses on studies to improve CS care. The aim is to identify groups of women in whom provided care is frequently not according to the evidence based guidelines, using guideline-based quality indicators, to identify barriers and facilitators for guideline non- 
adherence and to get insight into those groups of women in whom improvement is likely to be (cost) effective and feasible. We aim to answer the following questions:

1) What is optimal CS care? (Chapter 3)
a) Regarding planned CS:
In which situations
- is a CS advised?
- $\quad$ is a CS an equal option to a vaginal delivery?
- $\quad$ is a vaginal delivery the normal policy?
b) Regarding unplanned CS: Which preventive measures are advised to optimize the chance of a vaginal delivery?

2) What is the adherence to the recommendations in current care and which women are most likely to benefit from an intervention? (Chapter 3)

How many women:
a) are confronted with a specific clinical situation (frequency of occurrence and relevance for general care)?
b) receive optimal care (adherence to quality indicators) ?

3) What are factors hindering or helping professionals to provide optimal care to women? (Chapter 4)

4) Which factors (medical and non-medical) influence the unplanned (emergency) CS rate in nulliparous women? (Chapter 5,6) 


\section{References}

1. H. Dupuis, Naaktgeboren C, Noordam DJ, Spanjer J, FW van der Waals. Een kind onder het hart. 1987.ISBN 902909697

2. Perinatal Care in The Netherlands 2012. Utrecht: Foundation Perinatal Registration The Netherlands (PRN), 2013

3. Information Centre. NHS maternity statistics, England: 2008-09. Department of Health, 2009.

4. Menacker F, Hamilton BE. Recent trends in cesarean delivery in the United States. NCHS Data Brief 2010;35:1-8.

5. Kwee A, Elferink-Stinkens PM, Reuwer PJHM, Bruinse HW. Trends in obstetric interventions in the Dutch obstetrical care system in the period 1993-2002. Eur J Obstet Gynecol Reprod Biol 2007;132:70-75

6. World Health Organization. Appropriate technology for birth. Lancet 1985;2:436-7

7. Macfarlane AJ, Blondel B, Mohangoo AD, Cuttini M, Nijhuis J, Euro-Peristat Scientific Committee. Wide differences in mode of delivery within Europe: risk-stratified analyses of aggregated routine data from the Euro-Peristat study. BJOG 2016;123:559-68.

8. Ananth CV, Smulian JC, Vintzileos AM. The association of placenta previa with a history of cesarean delivery and abortion: A meta-analysis. Am J Obstet Gynecol 1997;177:1071-1078.

9. Zwart JJ, Richters JM, Öry F, Vries de JIP, Bloemenkamp KWM, Roosmalen van J. Uterine rupture in the Netherlands: a nationwide population-based cohort study. BJOG 2009;116:1069-1080.

10. Liu S, Liston RM, Joseph KS, Heaman M, Sauve R, Kramer MS, for the Maternal Health Study Group of the Canadian Perinatal Surveillance System. Maternal mortality and severe morbidity associated with low-risk planned caesarean delivery versus planned vaginal delivery at term. CMJH 2007;176:455-460

11. Lumbiganon P, Laopaiboon M, Gülmezoglu AM, Souza JP, Taneepanichskul S, Ruyan P, et al. World Health Organization Global Survey on Maternal and Perinatal Health Research Group: Method of delivery and pregnancy outcomes in Asia: the WHO global survey on maternal and perinatal health 2007-08. Lancet 2010;375:490-499.

12. Rossi AC, Lee RH, Chmait RH. Emergency postpartum hysterectomy for uncontrolled postpartum bleeding: a systematic review. Obstet Gynecol 2010;115:637-644

13. NICE Clinical Guideline: Caesarean section. CG132. 23-11-2011.

14. Bragg F, Cromwell DA, Edozien LC, Gurol-Urganci I, Mahmood TA, Templeton A, et al. Variation in rates of caesarean section among English NHS trusts after accounting for maternal and clinical risk: cross sectional study. BMJ 2010;341:C5065.

15. Menacker F, Declercq E, Macdorman MF. Cesarean delivery: background, trends, and epidemiology. Semin Perinatol 2006;30:235-41.

16. Le Ray C, Blondel B, Prunet C, Khireddine I, Deneux-Tharaux C, Goffinet F. Stabilizing the caesarean section rate: which target population? BJOG 2014;

17. Zhang J, Troendle J, Reddy UM, Laughon SK, Branch DW, Burkman R, et al. Contemporary cesarean delivery practice in the United States. Am J Obstet Gynecol 2010;203:326

18. Brennan DJ, Murphy M, Robson MS, O'Herlihy C. The singleton, cephalic, nulliparous woman after 36 weeks of gestation: contribution to overall caesarean delivery rates. Obstet Gynecol 2011;117:273-279.

19. Grol R, Baker R, Moss F. Quality improvement research: understanding the science of change in health care. Qual Saf Health Care 2002;11:110-111.

20. Campbell SM, Braspenning J, Hutchinson A, Marshall MN. Research methods used in developing and applying quality 
CHAPTER 1

indicators in primary care. BMJ 2003;326:816-819.

21. Lawrence M, Olesen F. Indicators of Quality in Health Care. Eur J Gen Pract 1997;3: 103-108.

22. Grol R. Improving the quality of medical care: building bridges among professional pride, payer profit, and patient satisfaction. JAMA 2001;286:2578-2585. 

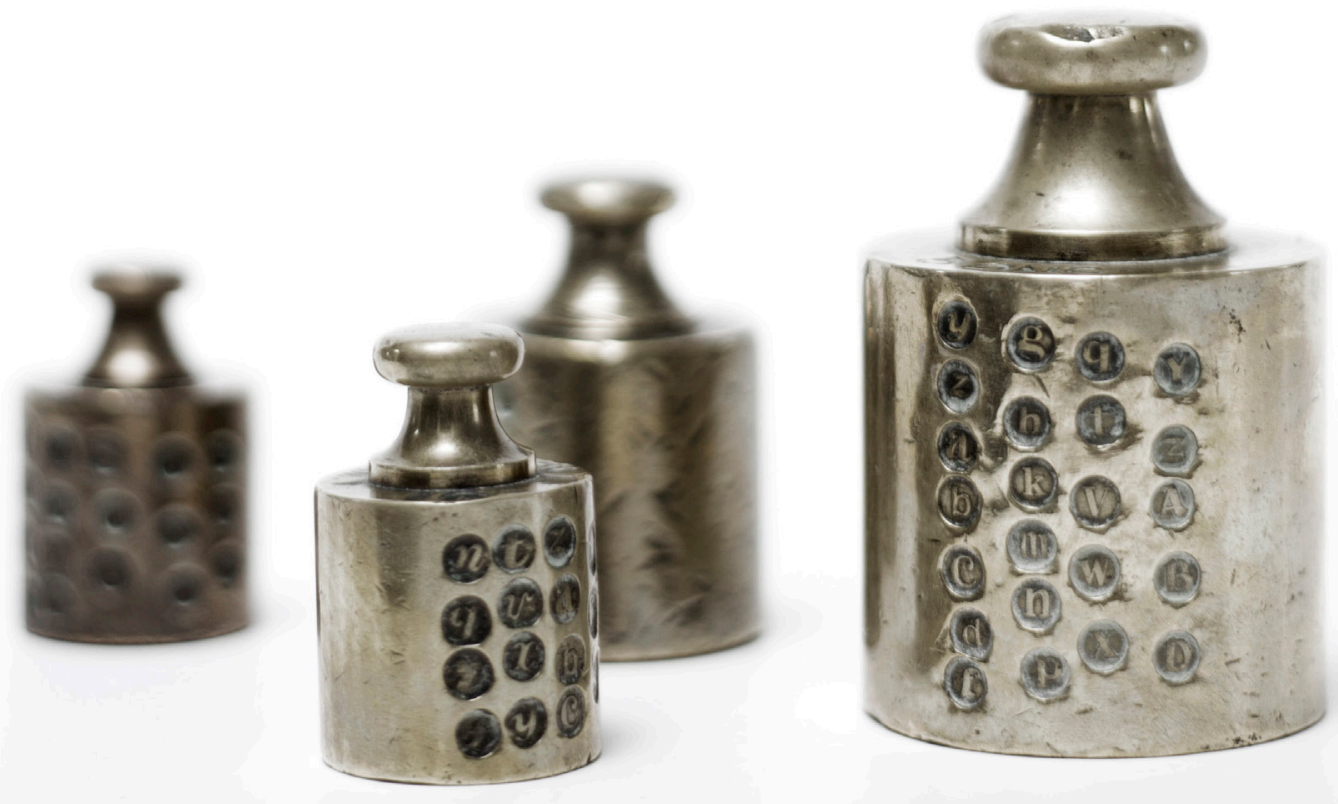


\section{SIMPLE: Implementation of recommendations from international evidence-based guidelines on caesarean sections in the Netherlands. Protocol for a controlled before and after study.}

Sonja Melman, Ellen NC Schoorel, Carmen Dirksen, Anneke Kwee, Luc Smits,

Froukje de Boer, Madelaine Jonkers, Mallory D Woiski, Ben Willem J Mol, Johannes PR Doornbos, Harry Visser, Anjoke JM Huisjes, Martina M Porath, Friso MC Delemarre, Simone MI Kuppens, Robert Aardenburg, Ivo MA Van Dooren, Francis PJM Vrouenraets, Frans TH Lim, Gunilla Kleiverda, Paulien CM van der Salm, Karin de Boer, Marko J Sikkema, Jan G Nijhuis, Rosella PMG Hermens, Hubertina CJ Scheepers 


\section{Abstract}

\section{Background}

Caesarean section (CS) rates are rising worldwide. In the Netherlands, the most significant rise is observed in healthy women with a singleton in vertex position between 37 and 42 weeks gestation, whereas it is doubtful whether an improved outcome for the mother or her child was obtained. It can be hypothesized that evidence-based guidelines on CS are not implemented sufficiently.

Therefore, the present study has the following objectives: to develop quality indicators on the decision to perform a CS based on key recommendations from national and international guidelines; to use the quality indicators in order to gain insight into actual adherence of Dutch gynaecologists to guideline recommendations on the performance of a CS; to explore barriers and facilitators that have a direct effect on guideline application regarding CS; and to develop, execute, and evaluate a strategy in order to reduce the CS incidence for a similar neonatal outcome (based on the information gathered in the second and third objectives).

\section{Methods}

An independent expert panel of Dutch gynaecologists and midwives will develop a set of quality indicators on the decision to perform a CS. These indicators will be used to measure current care in 20 hospitals with a population of 1,000 women who delivered by CS, and a random selection of 1,000 women who delivered vaginally in the same period. Furthermore, by interviewing healthcare professionals and patients, the barriers and facilitators that may influence the decision to perform a CS will be measured. Based on the results, a tailor-made implementation strategy will be developed and tested in a controlled before-and-after study in 12 hospitals (six intervention, six control hospitals) with regard to effectiveness, experiences, and costs.

\section{Discussion}

This study will offer insight into the current CS care and into the hindering and facilitating factors influencing obstetrical policy on CS. Furthermore, it will allow definition of patient categories or situations in which a tailor-made implementation strategy will most likely be meaningful and cost effective, without negatively affecting the outcome for mother and child. 


\section{Background}

This study will offer insight into the current CS care and into the hindering and facilitating factors influencing obstetrical policy on CS. Furthermore, it will allow definition of patient categories or situations in which a tailor-made implementation strategy will most likely be meaningful and cost effective, without negatively affecting the outcome for mother and child. The worldwide rise in caesarean section (CS) rate is a major healthcare issue, with rates reported as high as 32\% in the United States (US) and 37\% in Brazil. [1,2]. In the Netherlands, the overall CS rate has increased from $8.1 \%$ to $13.6 \%$ over the recent decade. Although this rise is relatively low compared to other countries, a striking detail is that the most impressive rise, in absolute numbers, was among healthy women with a singleton in vertex position between 37 and 42 weeks gestation [3]. However, an increasing CS rate does not imply an improved outcome for mother and infant [4]. CS are associated with an increased risk of maternal mortality as well as serious morbidity, such as admission to the intensive care unit (Odds Ratios (ORs) between 30.8 and 63.4), hysterectomy (ORs between 3.2 and 13.5), and puerperal infection (OR 3.0) [5-7].

Besides the short-term risks, CS have an impact on the mother's future reproductive health, for example uterine rupture, placenta praevia, or placenta accreta $[8,9]$.

There is no evidence suggesting a better neonatal outcome from the increased CS rate in terms of mortality, intracranial haemorrhage, or impaired neurological development in the general population $[10,11]$. In fact, an elective CS performed before 39 completed weeks is associated with respiratory distress and admission to the neonatal intensive care unit $[11,12]$.

The question arises what causes the worldwide increase in CS rate considering the fact that in most situations there are no apparent benefits of a CS for mother and child; the costs are higher compared to vaginal birth [5]; and the incidence of both maternal and neonatal complications are increased. There are concerns about the increasing rate of planned CS as well as a declining rate of vaginal birth after a previous CS (VBAC) in the US and Australia $[13,14]$.

To optimize CS practice, the Royal College of Obstetricians and Gynaecologists (RCOG) developed an evidence-based guideline (NICE: National Institute of Clinical Evidence) with clear recommendations for obstetric care. Similar recommendations, which have a direct effect on the decision to perform a CS, are also mentioned in the different guidelines of the Dutch Society of Obstetrics and Gynaecology (NVOG), Society of Obstetricians and Gynaecologists of Canada (SOGC), American College of Obstetrics and Gynaecology (ACOG), and National Guideline Clearinghouse from the US department of health and human services (NGC). 
Despite the introduction of evidence-based guidelines, the CS rate continues to increase. We hypothesize that poor adherence to the guidelines plays a key role in the rising CS rate. In order to optimize adherence to the CS guidelines, the stepwise model by Grol can be used to select the proper strategies $[15,16]$. The first step in this model is to analyze the current care (measured by valid quality indicators) compared to the optimal care as described in evidence-based guidelines, and to determine which barriers and facilitators might influence the implementation of optimal care. Subsequently, a tailor-made implementation strategy can be developed with activities applied to the determined barriers. In the last step, the strategy is executed and evaluated in terms of effectiveness, feasibility, and costs.

In view of the rising CS rate, this study aims are:

1. To develop a set of quality indicators on the decision to perform a CS based on key recommendations of both Dutch and international guidelines.

2. To gain insight into actual adherence of Dutch gynaecologists to guideline recommendations on the performance of CS.

3. To explore barriers and facilitators that have a direct effect on application of guideline recommendations regarding CS.

4. To develop, execute and evaluate a strategy in order to improve care and possibly decrease the CS incidence for a similar neonatal outcome, based on the information gathered in steps two and three.

\section{Methods}

The four aims were approached in four parts: the development of quality indicators, the assessment of current $t$ care, the identification of barriers and facilitators, and the development of a tailored implementation strategy and executing and evaluating this strategy in a clustered controlled before-and-after study (CBA).

\section{The development of quality indicators}

\section{Design and methods}

In order to measure current Dutch practice on CS, quality indicators regarding the process, structure, and outcome of care need to be developed. This will be achieved according to the RAND-modified Delphi method $[17,18]$. The indicators will be based on key recommendations extracted from the guidelines of several international obstetric organisations (RCOG, NVOG, SOGC, ACOG and NGC). These key recommendations will be evaluated in two rounds by an independent expert panel consisting of Dutch obstetricians and midwives. In the first round, a questionnaire will be developed on three subjects (planned CS, emergency CS, and methods 
to reduce the CS rate). The questionnaire will be sent to the experts who will be asked to individually rate the key recommendations on a 9-point Likert scale ranging from 1 to 9 ('not relevant' to 'extremely relevant' for measuring the quality of CS care). Furthermore, a ranking of the key recommendations will be asked per subject to ultimately extract those indicators considered to be most important for quality-of-care measurement. The experts also have the opportunity to add comments or suggest additional recommendations they consider suitable as a quality indicator. The returned questionnaires will be analysed based on the ratings of the recommendations on the 9-point Likert scale, and the median score of these items will be calculated and rated as described previously by Campbell [19]. Furthermore, scoring variables reflecting the ranking of the items in each of the three subjects will be developed (e.g., in a top 3 ranking, a first ranking creates 3 points, a second ranking 2 points, and a third ranking 1 point).

The second round consists of a consensus meeting where the experts will receive their individual as well as the overall results of the first round to promote discussion. The aim of this meeting is to reach consensus on those recommendations that are most suitable for assessing the quality of care on performing CS. After consensus is reached, the recommendations will be operationalized into a set of measurable quality indicators.

\section{Study population and setting}

A representative, national expert panel consisting of obstetricians and midwives (about 12 to 15 experts) will be invited. The obstetricians and midwives will have worked at various types of hospitals, ranging from small regional hospitals to university hospitals.

\section{Outcome measures}

The outcome of the first step of the study is a set of valid quality indicators regarding the decision to perform a CS which can then be used to measure the current practice.

\section{The assessment of current care}

\section{Design and methods}

A retrospective medical record search based on the set of quality indicators will be performed in order to assess the Dutch gynaecologists' adherence to the CS guideline recommendations. Adherence to these indicators will be quantified, as well as the variation in care and adherence between the participating hospitals. To gain insight into the current Dutch care compared to international care, the CS percentages of the different risk groups will be calculated according to the Robson classification (Table 1) [20]. Furthermore, the maternal mortality or severe acute morbidity (Table 2) [21], and perinatal mortality or serious morbidity ( $\mathrm{pH}<7.00$, Apgar $5 \mathrm{~min}<7$, and NICU admission) will be noted. This study 
will provide us with information about current practice on CS in the Netherlands and insight into the effects on outcome of mother and child.

Table 1. Ten-group classification according to Robson

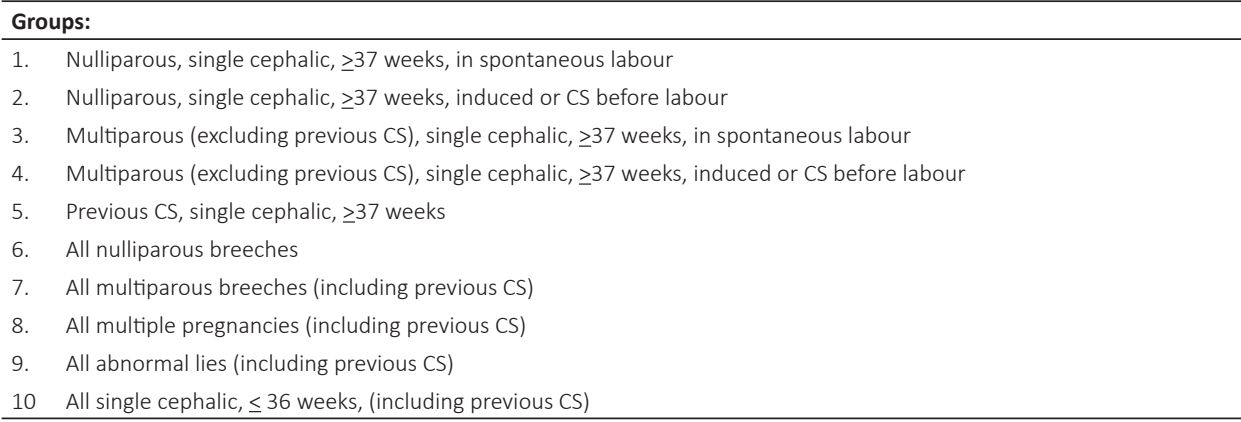

Table 2. Inclusion criteria for severe acute maternal morbidity

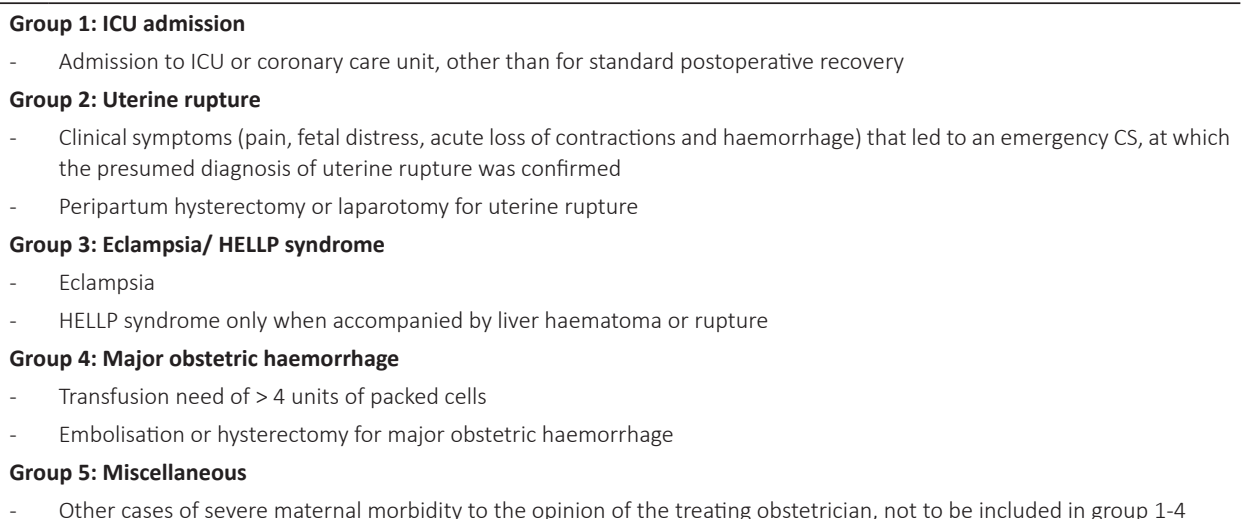

\section{Study population and setting}

In order to create a representative view of the current obstetrical care in The Netherlands, a multi-centre study will be carried out. Twenty hospitals of different Dutch regions will participate in this study, including university teaching hospitals, non-university teaching hospitals and nonuniversity, non-teaching hospitals. The present study will take place in the setting of a Dutch Obstetric Research Consortium in which all the participating hospitals collaborate.

In the participating hospitals, data on basic obstetrical care and adherence to the quality indicators will be collected. Per hospital 100 women will be selected from the local database: 50 women who delivered by CS and a random set of 50 women who delivered vaginally in the 
same time period. Exclusion criteria will be a major fetal congenital malformality and fetal death prior to onset of delivery.

\section{Outcome measures}

The main outcome is adherence to the guideline recommendations, based on the adherence to the quality indicators. Therefore, basic obstetrical data and indicator specific data will be gathered. For example, consider the indicator 'every woman with a child in breech presentation at 34 to 36 weeks gestation should be offered external cephalic version unless a contraindication for external cephalic version is present.' This implies that we need to assess the incidence of breech presentation at 34 to 36 weeks gestation, as well as data that show whether an external cephalic version is being offered. Furthermore, we will note in which cases this procedure was not offered for a valid reason. This will allow us to determine the frequencies of adherence for this indicator.

The secondary outcomes are the number of preventable CS, and Dutch practice as compared to international data using the Robson criteria.

\section{Sample size considerations}

Assuming an adherence to the guidelines of $75 \%$, an alpha of 0.05 , and a precision of the estimation of $5 \%, 300$ patients must be included. However, this number has to be adapted to take clustering of data across clinicians and within obstetrical departments into account. Assuming an intra-cluster correlation (ICC) of 0.2 and 80 professionals in 20 hospitals, 960 medical records need to be analysed. In order to compensate for loss to follow-up or incomplete data, 1,000 women with a CS will be included in 20 hospitals within a timescale of three to four months. In order to enable the calculation of specific events, as described in 'outcome measures,' a random selection of 1,000 women with a vaginal birth will be included.

Thus, there will be 2,000 participants, i.e., 1,000 women after a caesarean delivery and 1,000 women after a vaginal birth. Sampling fraction will be adjusted to the fraction of women with CS in each individual hospital.

\section{Data analysis}

The frequencies of adherence per quality indicator will be calculated. This will be calculated by dividing the total number of women who apply for an indicator and for whom care was appropriate by the total number of women who apply for an indicator. For example, women with a child in breech presentation between 34 to 36 weeks of gestation, without contraindication for external cephalic version, should have been offered an external cephalic version. Adherence is the total number of women with a child in breech presentation 
between 34 to 36 weeks of gestation without contraindication for external cephalic version, in whom an external version was offered, divided by the total number of women with a child in breech presentation between 34 to 36 weeks of gestation without contraindication for external cephalic version.

\section{Barrier and facilitator study}

\section{Design and methods}

To determine the barriers and facilitators that influence the decision to perform a CS for healthcare professionals and patients, a qualitative study will be performed. The setting for guideline implementation will be analysed. Focus group interviews will be held among healthcare professionals (obstetricians, residents, and midwives) to discover factors that determine the decision to perform a CS or not. The interviewer will explore the following categories of influencing factors: features of the guidelines itself; features of the target group of professionals who should use the guidelines; features of patients who have to accept or contribute to the use of the guidelines; features of the social setting and social network of the professionals; and features of the organizational, economic, and administrative context. Remarks by professionals will be classified into categories of potential determining factors following this theoretical framework. The 'prevalence' of the features mentioned in the focus group interviews will be quantified in a survey with questionnaires among the different professionals.

Similarly, depending on the outcome of the current care study, semi-structured interviews will be held with patients in a detailed study to discover relevant factors that influence the patients' decision to choose a CS or vaginal delivery.

\section{Study population and setting}

In different hospital types (university, non-university teaching, and non-university nonteaching hospitals) interviews will be held among healthcare professionals (obstetricians, residents and midwives) as well as patients. Focus group interviews among 8 to 12 healthcare professionals will be planned. To assess whether the factors mentioned in the focus group interviews are structural, the 'prevalence' of these factors will be assessed using a survey with questionnaires among obstetric gynaecologists, residents, and midwives in the Netherlands. The questionnaires will be sent to the professionals via email addresses we will obtain from the national professional organisations of both professions. Among patients, semi-structured interviews will be held. These patients will be selected in the abovementioned hospitals from the current care study. The interviews will be conducted with those women belonging to the non-adherence subgroups (such as breech, non-progressing labour, or maternal request) to whom a possible implementation should be directed. Approximately ten to fifteen women 
will be interviewed until no new information emerges during the interviews.

\section{Outcome measures}

The main outcome measures are the barriers and facilitators for adherence to the quality indicators for performing a CS.

\section{Data analysis}

Using Atlas, the qualitative software package, a qualitative analysis will be performed on the barriers and facilitators that are presented in the interviews among healthcare professionals and patients. The transcribed interview will be marked and coded with barriers and facilitators according to the framework used to structure the interviews: features of the guidelines, professionals, patients, social setting, and organization. These influencing factors will be quantified among all Dutch gynaecologists and midwives by means of questionnaires. The analyses of the questionnaires will be descriptive (e.g., frequencies and means).

\section{Controlled before-and-after study}

\section{Design and methods}

Based on the results of the current care study and the barrier and facilitator study, one or more target groups for a tailor-made implementation strategy will be identified. Target groups will be selected with focus on women with both a high incidence of the indicator (our hypothesis is that this will include, for example, non-progressing labour and previous CS) and low indicator adherence.

A tailor-made implementation strategy will be developed in order to increase adherence to the CS quality indicators. This strategy will be executed and evaluated in a clustered CBA study in 12 hospitals (six intervention, six control hospitals) (see sample size calculation) in terms of effectiveness, experiences, and costs. It is likely that a strategy with different implementation elements is needed because several barriers for implementation of recommendations may exist at different levels. This will probably result in a combined intervention directed at the level of professionals, patients, and the organisation.

\section{Study population and setting}

The implementation strategy will be executed and evaluated in 12 hospitals (see sample size calculation) that also participated in the current care study: six intervention hospitals in which the newly developed strategy will be applied; and six control hospitals in which care as usual will be offered. In order to select these 12 hospitals, all 20 hospitals of the current care study will be categorized into university, non-university teaching, and non-university non-teaching hospitals (three categories). Within these three categories, possible hospital 
pairs will be made based on pre-intervention adherence to quality indicators and CS rates, as measured in the current care study. To get a sample representative for the Dutch setting, in total two university hospitals, six non-university teaching hospitals and four non-university, non-teaching hospitals will be asked to participate. Subsequently, the participating hospitals have to be assigned to the intervention and control group. This will be done per stratum and based on geographic region. The evaluation will include an effect, process, and cost analysis. Just as in de current care study, the effects will be measured both at medical outcome level (i.e., CS rates and complication rates) and on guideline adherence level. Satisfaction with and applicability of the tailor-made implementation strategy for both patients and healthcare professionals will be measured in a process evaluation. Information regarding the process will be gathered in a qualitative study in the hospitals in which the implementation strategy was applied. Individual interviews will take place among the involved healthcare professionals and patients to gather data about experiences with the changed care. During the interview, they also will be asked about which elements of the tested strategy they specifically used to implement the evidence-based guidelines; how satisfied they are with the different elements; and their opinion about the feasibility of the different elements.

Furthermore, a cost analyses of the tested implementation strategy will take place with respect to three aspects: 1) the rate at which the guideline recommendations are already applied; 2) the costs of the implementation strategy (taking into account the development of the strategy, training of healthcare professionals, and possible extra costs regarding both time and medical costs) and 3) the effectiveness of the implementation strategy.

In order to measure the effectiveness of the implementation strategy both the effects on medical outcome (i.e., CS rates, complication rates) and adherence to CS quality indicators will be measured. The cost-effectiveness of the implementation strategy will be expressed as the incremental costs per extra patient treated according to the CS quality indicators, compared to the 'do-nothing' strategy.

\section{Outcome measures}

The primary outcome is effectiveness of the implementation strategy, which is defined as the observed increase in adherence to the developed quality indicators with regard to the chosen target group (for example non-progressing labour or previous CS) between the intervention and control hospitals and the actual CS rates in both groups. Secondary outcome measures are experiences and satisfaction of healthcare providers and patients with the implementation strategy as well as applicability and costs. 


\section{Sample size considerations}

For a sample size calculation, the target group and the adherence to the quality indicators regarding this target group are necessary. These data will be available after performing the current care as well as the barrier study. Based on these data, the sample size can be calculated. In this calculation, we will take into account clustering of patients within professionals and hospitals. We expect most of the clustering at professional level and presume an inclusion of a number of professionals per hospital and a number of patients per professional. For pragmatic reasons, we will include at most 12 out of the 20 hospitals of the current care measurement. This sample of hospitals has to be representative for the Dutch setting, i.e., a total of two university hospitals, six non-university teaching hospitals, and four non-university, non-teaching hospitals.

\section{Data analysis}

To assess the effectiveness of the implementation strategy, the proportion of patients that are treated in accordance with the guidelines before and after implementation of the guidelines in both the intervention and control hospitals will be measured. Medical outcome measures will include CS rates and maternal as well as neonatal complications related to vaginal delivery or CS. Multilevel multivariate analysis will be carried out to assess the independent effect of the implementation strategy on adherence to the CS quality indicators and medical outcome measures.

A qualitative descriptive analysis will be done in order to evaluate the process. Furthermore, by means of a questionnaire, the experiences of healthcare providers and patient satisfaction with the implementation strategy will be evaluated, and the outcomes will be descriptive.

The costs analysis will be performed from a healthcare perspective. The costs of the implementation process will be calculated on the basis of the time and materials invested based on activity-based costing ( $A B C$ ) approach, focusing on activities performed with costs accumulated at the activity level(s) of the healthcare implementation processes. The costs of implementation of the guidelines and consolidation consist of personnel and material costs. The input of resources will be assessed by collecting volumes of consumed resources, and multiplying these by the price of each resource unit. For collecting information on the input of the resources, registration forms will be completed by the people involved in the implementation and consolidation process. The prices of each resource unit will be based on standard costs [22], market prices, or self-determined costs. The medical costs used in de cost analysis will include CS rates and maternal and neonatal complications related to vaginal delivery or CS. The costs of implementation and costs of the changed medical care will be weighed against the proportion of patients that are treated according to the CS guideline, 
after implementation. The cost-effectiveness of implementation will be expressed as the incremental costs per extra patient treated according to the CS guideline, compared to the 'do-nothing' strategy (i.e., no implementation, for which data before implementation will be used).

\section{Ethical considerations}

The Medical Ethical Committee (CMO) of Maastricht (azM/UM) declared that no ethical approval was necessary for this study protocol.

\section{Discussion}

The CS rate in The Netherlands is comparatively low compared to other countries, but it is increasing especially in the group of healthy women with a singleton pregnancy in vertex position at term. One would expect this to coincide with improved outcomes for mothers and children, which is, however, not the case [5]. Although many suggestions considering the reason for this rise have been made, the answer is not yet clear. We hypothesize that incomplete guideline adherence is a possible cause for the current increase in CS rate. In this study we will determine current Dutch care regarding CS using quality indicators. We will use national as well as international guidelines to select the recommendations, resulting in at least a set of internationally accepted indicators.

Because we will also report the current CS rates by classification into the internationally accepted Robson Criteria, international comparison of incidences of CS rates in different subgroups will be possible. In that way, specific indicators and incidences of those indicators might be applicable elsewhere. Furthermore, we will focus on factors that influence guideline implementation, and thus optimal care in the barrier and facilitator analysis.

Although earlier reviews claimed that multifaceted strategies (combinations of many different interventions) are often effective, Grimshaw found that a higher number of intervention components was not related to higher effectiveness [23]. It seems plausible that combined interventions are only more effective than single interventions, if these are addressed at the specific barriers to change. This is also the conclusion of Chaillet et al.: in the obstetric setting in general and the CS setting in particular, prospective identification of efficient strategies and barriers to change is necessary to achieve a better adaptation of intervention and to improve clinical practice guideline implementation [24]. 
This study will hopefully result in one or more target groups with high incidence and low guideline adherence and the evaluation of an implementation strategy to improve care. For example, non-progressing labour is known to be one of the major reasons to perform a CS. Should guideline adherence in these women be low, an intervention based both on informing women and reminders on optimal care for caregivers could be an option. Another possible target group might be women with a previous CS. Although in general, the VBAC rate was previously reported higher in the Netherlands than in some other countries, recent data are lacking. Improvement of care for these women could consist of a decision aid to improve counselling. Both types of interventions are also possibly effective outside the Netherlands. The ultimate aim of our study is to implement the national and international evidence-based guidelines on CS in all Dutch hospitals in order to reduce the incidence of CS and improve the outcome for mother and child. Furthermore, this study provides a framework for future studies to enable improvement of guideline adherence and reduction of the CS rate. 


\section{References}

1. Menacker F, Hamilton BE: Recent trends in cesarean delivery in the United States. NCHS Data Brief 2010, 35:1-8.

2. Betrán AP, Merialdi M, Lauer JA, Bing-Shun W, Thomas J, Van Look P, Wagner M: Rates of caesarean section: analysis of global, regional and national estimates. Paediatr Perinat Epidemiol 2007, 21:98-113.

3. Kwee A, Elferink-Stinkens PM, Reuwer PJHM, Bruinse HW: Trends in obstetric interventions in the Dutch obstetrical care system in the period 1993-2002. Eur J Obstet Gynecol Reprod Biol 2007, 132:70-75.

4. Villar J, Carroli G, Zavaleta N, Donner A, Wojdyla D, Faundes A, Velazco A, Bataglia V, Langer A, Narváez A, Valladares E, Shah A, Campodónico L, Romero M, Reynoso S, de Pádua KS, Giordano D, Kublickas M, Acosta A: World Health Organization 2005 Global Survey on Maternal and Perinatal Health Research Group: Maternal and neonatal individual risks and benefits associated with caesarean delivery: multicentre prospective study. BMJ 2007, 335:1025-1036.

5. Souza JP, Gülmezoglu A, Lumbiganon P, Laopaiboon M, Carroli G, Fawole B, Ruyan P: WHO Global Survey on Maternal and Perinatal Health Research Group: Caesarean section without medical indications is associated with an increased risk of adverse short-term maternal outcomes: the 2004-2008 WHO Global Survey on Maternal and Perinatal Health. BMC Med 2010, 8:71

6. Liu S, Liston RM, Joseph KS, Heaman M, Sauve R, Kramer MS, for the Maternal Health Study Group of the Canadian Perinatal Surveillance System: Maternal mortality and severe morbidity associated with low-risk planned caesarean delivery versus planned vaginal delivery at term. CMJH 2007, 176:455-460.

7. Lee YM, D’Alton ME: Cesarean delivery on maternal request: maternal and neonatal complications. Curr Opin Obstet Gynecol 2008, 20:597-601.

8. Ananth CV, Smulian JC, Vintzileos AM: The association of placenta previa with a history of cesarean delivery and abortion: A metaanalysis. Am J Obstet Gynecol 1997, 177:1071-1078.

9. Rossi AC, Lee RH, Chmait RH: Emergency postpartum hysterectomy for uncontrolled postpartum bleeding: a systematic review. Obstet Gynecol 2010, 115:637-644.

10. Tita AT, Landon MB, Spong CY, Lai Y, Leveno KJ, Varner MW, Moawad AH, Caritis SN, Meis PJ, Wapner RJ, Sorokin Y, Miodovnik M, Carpenter M, Peaceman AM, O'Sullivan MJ, Sibai BM, Langer O, Thorp JM, Ramin SM, Mercer BM, Eunice Kennedy Shriver NICHD Maternal-Fetal Medicine Units Network: Timing of elective repeat cesarean delivery at term and neonatal outcomes. N Eng J Med 2009, 360:111-120.

11. Yee W, Amin $\mathrm{H}$, Wood S: Elective cesarean delivery, neonatal intensive care unit admission, and neonatal respiratory distress. Obstet Gynecol 2008, 111:823-828.

12. Wilmink FA, Hukkelhoven CW, Lunshof S, Mol BW, van der Post JA, Papatsonis DN: Neonatal outcome following elective cesarean section beyond 37 weeks of gestation: a 7-year retrospective analysis of a national registry. Am J Obstet Gynecol 2010, 202:250. e1-8.

13. MacDorman M, Declercq E, Menacker F: Recent trends and patterns in cesarean and vaginal birth after cesarean (VBAC) deliveries in the United States. Clin Perinatol 2011, 38:179-92.

14. Zhang J, Troendle J, Reddy UM, Laughon SK, Branch DW, Burkman R, Landy HJ, Hibbard JU, Haberman S, Ramirez MM, Bailit JL, Hoffman MK, Gregory KD, Gonzalez-Quintero VH, Kominiarek M, Learman LA, Hatjis CG, van Veldhuisen P, Consortium on Safe Labor: Contemporary cesarean delivery practice in the United States. Am J Obstet Gynecol 2010, 
203:326. e1-326.e10.

15. Grol R: Beliefs and evidence in changing clinical practice. BMJ 1997, 315:418-421.

16. Grol R: Improving the quality of medical care: building bridges among professional pride, payer profit, and patient satisfaction. JAMA 2001, 286:2578-2585.

17. Hermens RP, Ouwens MM, Vonk-Okhuijsen SY, van der Wel Y, Tjan-Heijnen VC, van den Broek LD, Ho VK, Janssen-Heijnen ML, Groen HJ, Grol RP, Wollersheim HC: Development of quality indicators for diagnosis and treatment of patients with non-small cell lung cancer: a first step toward implementing a multidisciplinary, evidence-based guideline. Lung Cancer 2006, 54:117-24.

18. Mourad SM, Hermens RP, Nelen WL, Braat DD, Grol RP, Kremer JA: Guideline-based development of quality indicators for subfertility care. Hum Reprod 2007, 22:2665-2672.

19. Campbell SM, Braspenning J, Hutchinson A, Marshall M: Research methods used in developing and applying quality indicators in primary care. Qual Saf Health Care 2002, 11:358-364.

20. Robson MS: Can we reduce the caesarean section rate? Best Pract Res Clin Obstet Gynaecol 2001, 15:179-194.

21. Van Dillen J, Mesman JAJM, Zwart JJ, Bloemenkamp KWM, Van Roosmalen J: Introducing maternal morbidity audit in the Netherlands. BJOG 2010, 117:416-421.

22. Oostenbrink JB, Buijs-Van Der Woude T, Van Agthoven M, Koopmanschap MA, Rutten FF: Unit costs of inpatient hospital days. PharmacoEconomics 2003, 21:263-271.

23. Grimshaw JM, Thomas RE, MacLennan G, Fraser C, Ramsay CR, Vale L, Whitty P, Eccles MP, Matowe L, Shirran L, Wensing M, Dijkstra R, Donaldson C: Effectiveness of guideline dissemination and implementation strategies. Health Technol Assess 2004, 8:1-72.

24. Chaillet N, Dumont A: Evidence-based strategies for reducing caesarean section rates: a meta-analysis. Birth 2007, 34:53-64. 


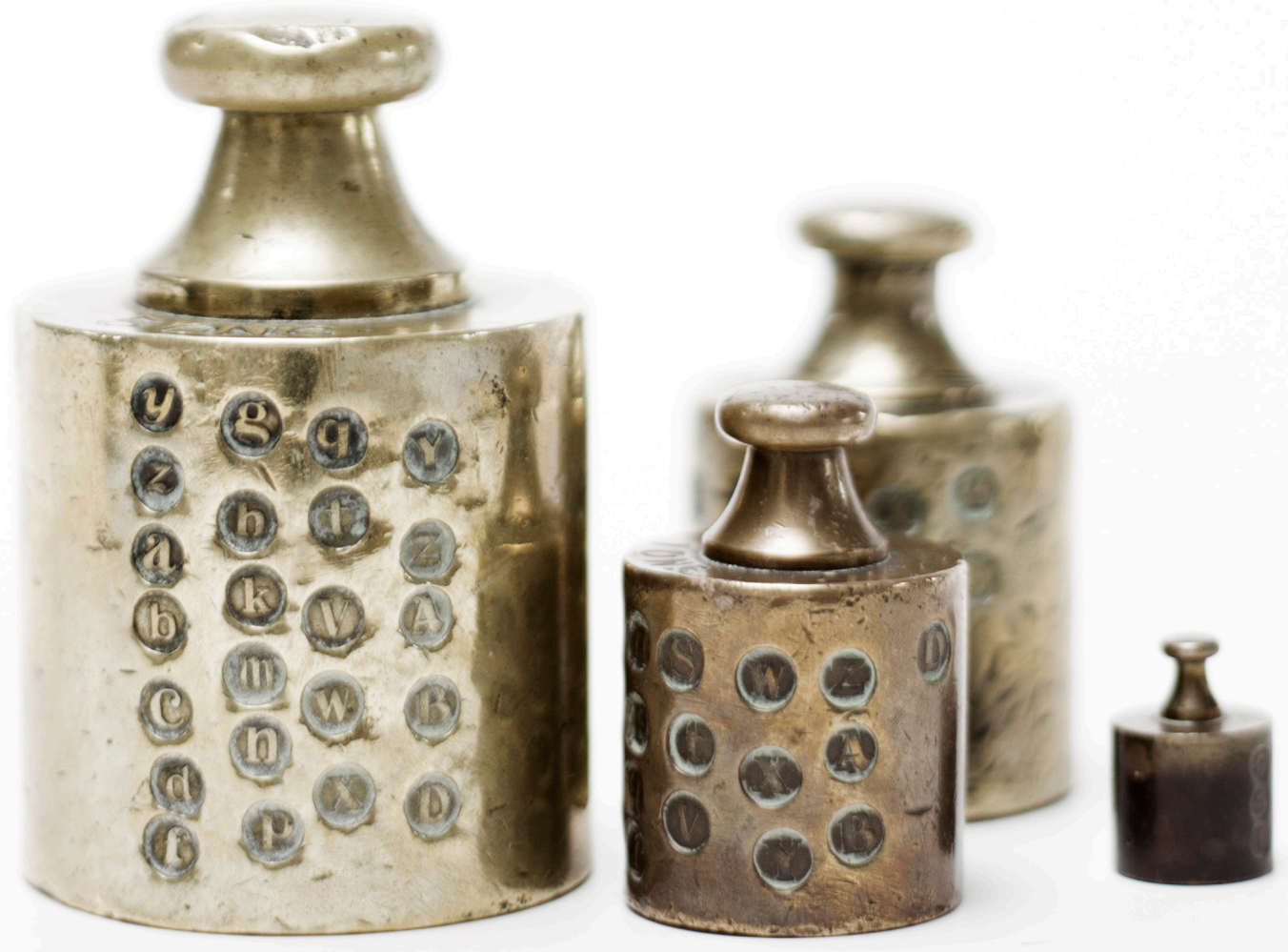




\section{Development and measurement of guidelines-based quality indicators of caesarean section care in The Netherlands: a RAND-modified Delphi procedure and retrospective medical chart review.}

Sonja Melman, Ellen C.N. Schoorel, Karin de Boer, Henriëtte Burggraaf, Jan B. Derks, Det van Dijk, Jeroen van Dillen, Carmen D. Dirksen, Johannes J. Duvekot, Arie Franx, Tom H.M. Hasaart, Anjoke J.M. Huisjes, Diny Kolkman, Sander van Kuijk, Anneke Kwee, Ben W. Mol, Mariëlle G. van Pampus, Alieke de Roon-Immerzeel, Jos J.M. van Roosmalen, Frans J.M.E. Roumen, Ellen Smid-Koopman, Luc Smits, Wilbert A. Spaans, Harry Visser, Wim J. van Wijngaarden, Christine Willekes, Maurice G.A.J. Wouters, Jan G. Nijhuis, Rosella P.M.G. Hermens, Hubertina C.J. Scheepers 


\section{Abstract}

\section{Background}

There is an ongoing discussion on the rising CS rate worldwide. Suboptimal guideline adherence may be an important contributor to this rise. Before improvement of care can be established, optimal CS care in different settings has to be defined. This study aimed to develop and measure quality indicators to determine guideline adherence and identify target groups for improvement of care with direct effect on caesarean section (CS) rates.

\section{Method}

Eighteen obstetricians and midwives participated in an expert panel for systematic CS quality indicator development according to the RAND-modified Delphi method. A multi-center study was performed and medical charts of 1024 women with a CS and a stratified and weighted randomly selected group of 1036 women with a vaginal delivery were analysed. Quality indicator frequency and adherence were scored in 2060 women with a CS or vaginal delivery.

\section{Results}

The expert panel developed 16 indicators on planned CS and 11 indicators on unplanned CS. Indicator adherence was calculated, defined as the number of women in a specific obstetrical situation in which care was performed as recommended in both planned and unplanned CS settings. The most frequently occurring obstetrical situations with low indicator adherence were: 1) suspected fetal distress (frequency $17 \%$, adherence $46 \%$ ), 2) non-progressive labour (frequency $12 \%$, CS performed too early in over $75 \%$ ), 3) continuous support during labour (frequency $88 \%$, adherence $37 \%$ ) and 4) previous CS (frequency $12 \%$ ), with adequate counselling in $15 \%$.

\section{Conclusions}

We identified four concrete target groups for improvement of obstetrical care, which can be used as a starting point to reduce CS rates worldwide. 


\section{Introduction}

There is a worldwide rise in caesarean section (CS) rates. Although the Netherlands has a relatively low CS rate (16.7\%) compared to the United Kingdom (24.6\%) and United States (32\%), the most impressive rise in CS rate is found in 'low risk pregnancies': healthy women with a singleton in cephalic position at term [1, 2, 3, 4]. The World Health Organization estimates a CS rate between $10-15 \%$ to be optimal [5]. Although a CS is a relatively safe procedure, it is associated with increased short term morbidity and mortality, with an increased risk of abnormal placentation and uterine rupture in future pregnancies [6, 7]. Furthermore, rising CS rates are not associated with improved outcome for mother and neonate $[8,9,10]$. A CS costs twice as much as a vaginal delivery, (1256 euro to 9652 euro extra depending on the country of origin [11]. Adding all costs of future morbidity and increased risk of future repeat CS, the estimated additional costs of one CS are 7500 euro.

The cause of the increasing CS rate is still unknown. Previous studies mostly focus on epidemiological data such as rising maternal age, maternal request for CS and decline in attempt of vaginal birth after CS $[12,13]$. Applying the Robson Ten Group Classification system, others mainly identified the nulliparous single cephalic term pregnancy, as well as the women with a previous CS to be important contributors to the total CS rate [14, $15,16]$. This neither reflects appropriate obstetrical care, nor shows which women need improvement of care. Our hypothesis is, that incomplete adherence to guidelines regarding the decision when to perform a CS might be an important explanation for the rising CS rate. This hypothesis is supported by hospital-level variation in CS rates, which cannot be explained by socio-demographic or clinical factors [12].

In recent decades, several international obstetrical organizations have developed evidencebased guidelines with recommendations for optimal care regarding the decision when to perform a CS. However, the crucial issue remains whether these recommendations are actually followed. In order to improve current CS care, it is of importance to gain insight into the extent of guideline implementation in daily practice. Before this can be measured, valid quality indicators for optimal care have to be systematically developed $[17,18]$.

In the present study, we apply a systematic method for development of evidence-based obstetrical quality indicators. Based on these indicators, we compare current Dutch care to optimal care as described in international evidence-based guidelines. This will allow the identification of target groups of women in which a tailor-made implementation strategy might improve care and reduce CS rates. 


\section{Methods}

\section{Development of CS quality indicators}

A systematic RAND-modified Delphi method was used to select a set of key recommendations appropriate for transcription into quality indicators [18]. These recommendations were extracted from national guidelines (NVOG: Dutch Society of Obstetricians and Gynaecologists, CBO: Centraal Begeleidings Orgaan, a Dutch organization aiming at improving the quality of care by health care professionals), international guidelines (RCOG: Royal College of Obstetricians and Gynaecologists, ACOG: American Congress of Obstetricians and Gynaecologists, and SOGC: Society of Obstetricians and Gynaecologists of Canada) and literature $[19,20]$. The national expert panel consisted of both obstetricians $(\mathrm{N}=13)$ and midwives $(\mathrm{N}=4)$ and were members of either the Dutch Society of Obstetrics and Gynaecology (NVOG) or the Royal Dutch Organization of Midwives (KNOV). The experts rated and discussed indicators on planned CS (including mode of delivery counselling and CS prevention) as well as indicators on unplanned CS ( in an iterative way. The exact procedure for indicator development is described in S1: Description of stepwise procedure of CS quality indicator development.

\section{Measurement of CS current care}

\section{Design and Setting}

We conducted a retrospective multi-center cohort study. This study was situated within the Dutch Obstetric Consortium, which is a research collaboration of obstetric clinics in The Netherlands (http://www.studies-obsgyn.nl).

\section{Study population}

In order to obtain a representative view of current CS care, this study was conducted in 21 hospitals: 5 university hospitals, 10 non-university teaching hospitals and 6 non-university, non-teaching hospitals located in different regions of The Netherlands. To gain real insight in current obstetrical care and measure quality indicator adherence, women with a CS and women with a vaginal delivery (VD) were included. For example, consider the situation of breech presentation. In such a situation, an external cephalic version should be offered. In order to study guideline adherence, all women with a fetus in breech presentation after 34 weeks need to be identified. In this case, adequate care is offering external cephalic version to women with a breech presentation after 34 weeks, independent of their acceptance or the result of the attempt.

Per hospital, the medical charts of 50 consecutive women who underwent a caesarean delivery as well as a random selection of 50 women who underwent a VD in the same period were analysed. Since it was inefficient to include and analyse all women with a VD, 
a randomization list was developed per hospital based on the local CS rate. For example, if the CS rate was 20\%, VD sampling rate was $0.25(0.25 * 80 \%=20 \%)$. We excluded cases with major fetal abnormalities (defined as 'abnormalities that interfere with standard obstetrical care or vaginal birth'), birth prior to 24 weeks of gestation and fetal demise prior to onset of delivery. Since the Medical Ethical Committee (CMO) of Maastricht (azM/UM) declared that no ethical approval was necessary for this study protocol, no informed consent was required. The patient data were anonymized.

\section{Data collection}

Trained research nurses from the Dutch Obstetric Consortium gathered the data. We extracted basic obstetrical data for all women from their individual medical charts; including data on previous deliveries (previous VD, CS) and current pregnancy (parity, singleton/ multiple gestation). Furthermore, we gathered indicator specific data for all women to enable calculation of adherence to each indicator. These data included conditions that might influence mode of delivery and existed prior to delivery (diabetes, hypertension) or developed either during pregnancy (suspected fetal macrosomia, intrauterine growth restriction) or during delivery (suspected fetal distress, non-progressive labour). Indicator specific data included ultrasound results, mode of delivery counselling, delivery specifics (e.g. use of ST-analysis or fetal scalp blood sampling, pain medication and oxytocin). We assessed indicator specific data for all women in order to evaluate whether care was provided according to guidelines.

\section{Sample size}

We assumed a mean adherence to the guidelines of $75 \%$, an alpha of 0.05 , and a precision of the estimation of 5\%. Next, we assumed an intra-cluster correlation (ICC) of 0.2 and 80 professionals in 20 hospitals. Taking clustering of data across clinicians and within obstetrical departments into account, 960 medical charts were needed for analyses. In order to compensate for loss to follow-up or incomplete data, at least 1,000 women with a CS needed to be included.

In order to enable the calculation of specific events (frequencies) as described in 'measurement of CS quality indicators', a random selection of 1000 women with a vaginal delivery were included. This resulted in the analysis of 50 women with a VD and 50 women with a CS per hospital.

\section{Statistical analysis}

To assess guideline adherence, performance scores per indicator were calculated, ranging from 0 to $100 \%$. This was done as follows: the number of women to whom the indicator applied and actual care was consistent with the indicator (numerator) was divided by the 
total number of women to whom the indicator applied (denominator). When an indicator was composed of aggregated items (e.g. the indicator 'request for CS without medical grounds'), we calculated additional sub percentages for each item. In this case, sub percentages were calculated for 3 additional items: 1. explore reason for CS request, 2. discuss (dis)advantages to CS delivery and 3. offer psychological counselling in case of fear of delivery. Analyses were performed using SPSS statistics 21.

Percentages were weighted for the hospital-specific sampling fractions used in sampling VDs. For example, if a sampling fraction of 0.25 was used in a particular hospital, data for each VD from that hospital counted four (1/0.25) times in the calculation of numerators and denominators.

\section{Results}

\section{Development of CS quality indicators}

Based on 51 recommendations, extracted from the guidelines, the stepwise procedure of indicator development (figure 1) resulted in a set of 27 CS quality indicators, including 14 indicators on planned CS (mode of delivery counselling (CS versus VD) 13 indicators on prevention of CS. The procedure of CS quality indicator development is given in the appendix of this article.

The final indicator set is given in Table 1. The indicators on planned CS are shown separately in Table S1 (Quality indicators on planned CS) in the appendix of this article.

\section{Study population}

All 21 hospitals were asked to provide data of 50 VD as well as 50 CS, which would result in a study population of 2100 women. There were 22 women who met the exclusion criteria. Not every hospital analysed the requested 100 women, resulting in an analysis of 2060 women. When adjusting for the random selection of vaginal deliveries, these 2060 women represent a total study population of 4687 women.

\section{Measurement of current care}

Table 2 shows the frequency of specific obstetrical events, as described by the indicators, as well as the performance scores (indicating adequate care) in the total study population ( $N=4687$ women) concerning: planned CS and unplanned CS. 


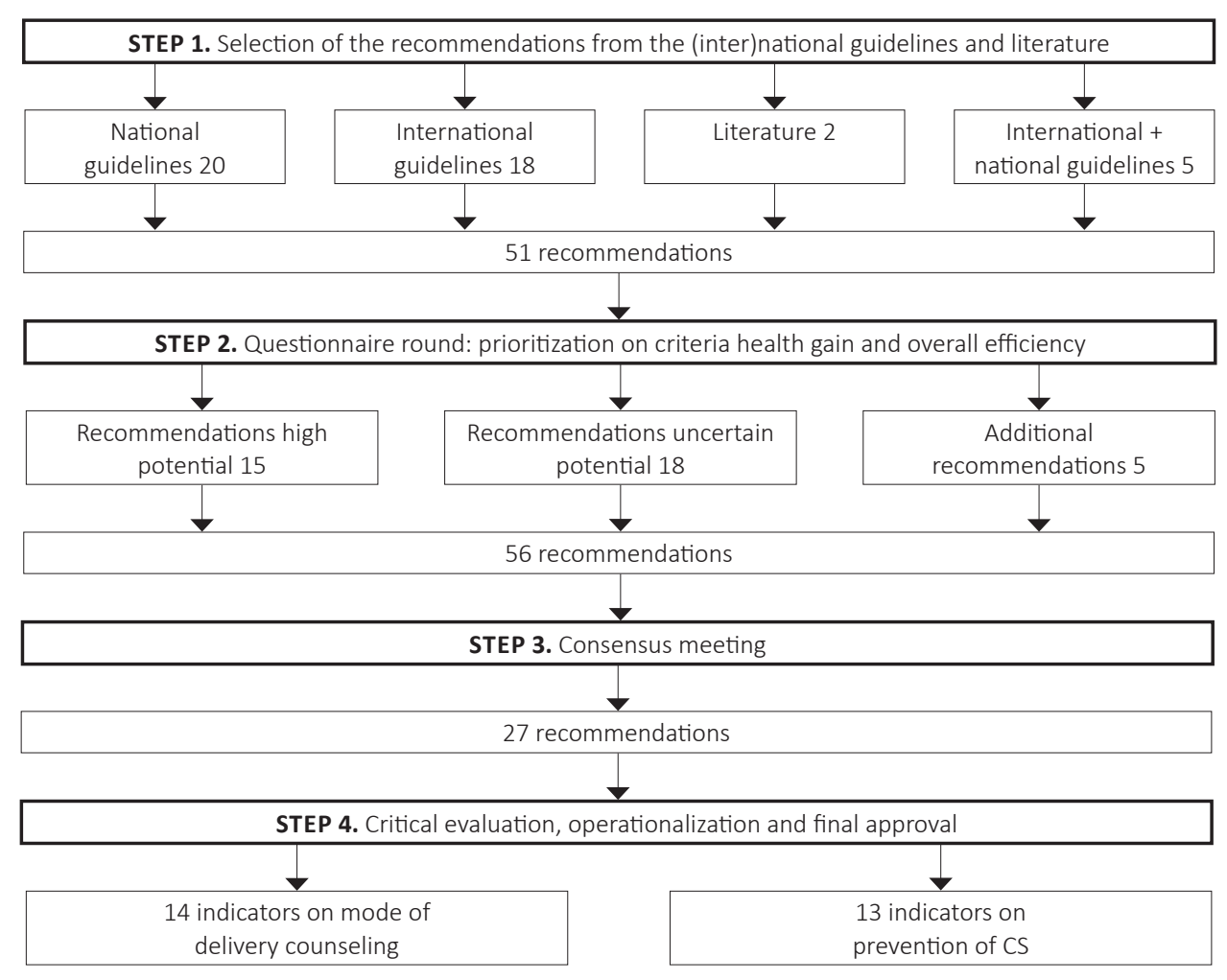

Fig. 1. Stepwise procedure of CS quality indicator development 
Table 1. Set of CS quality indicators

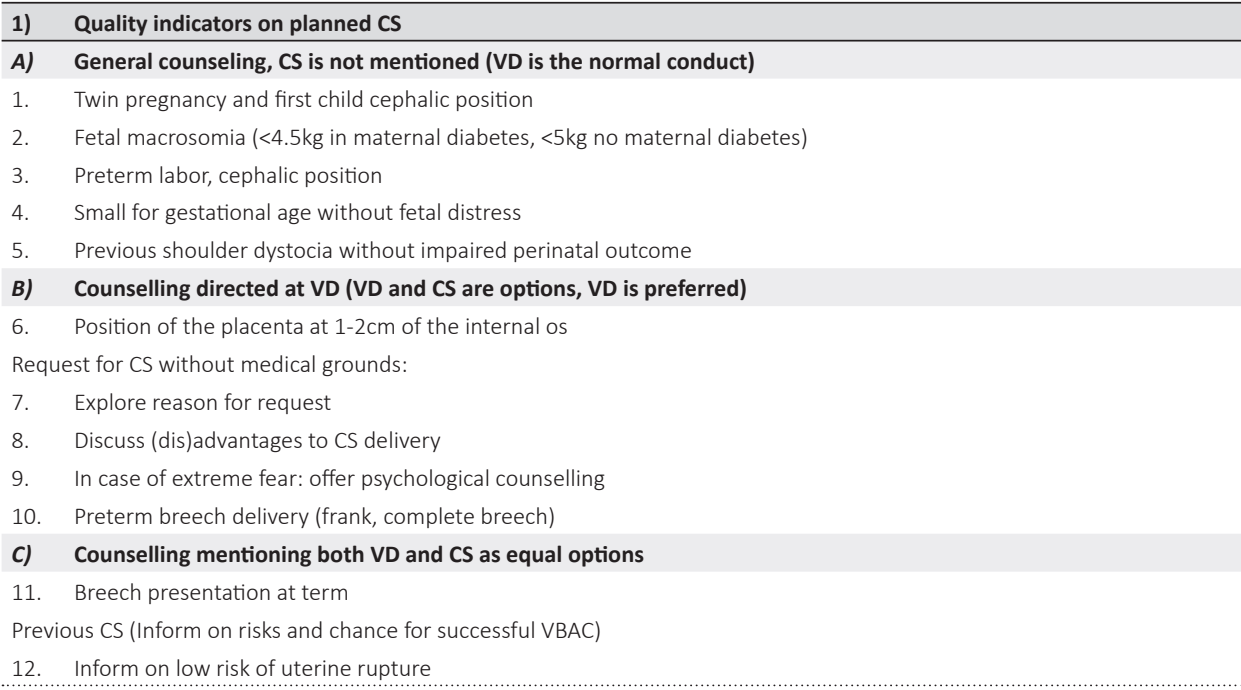

Table 1 continued.

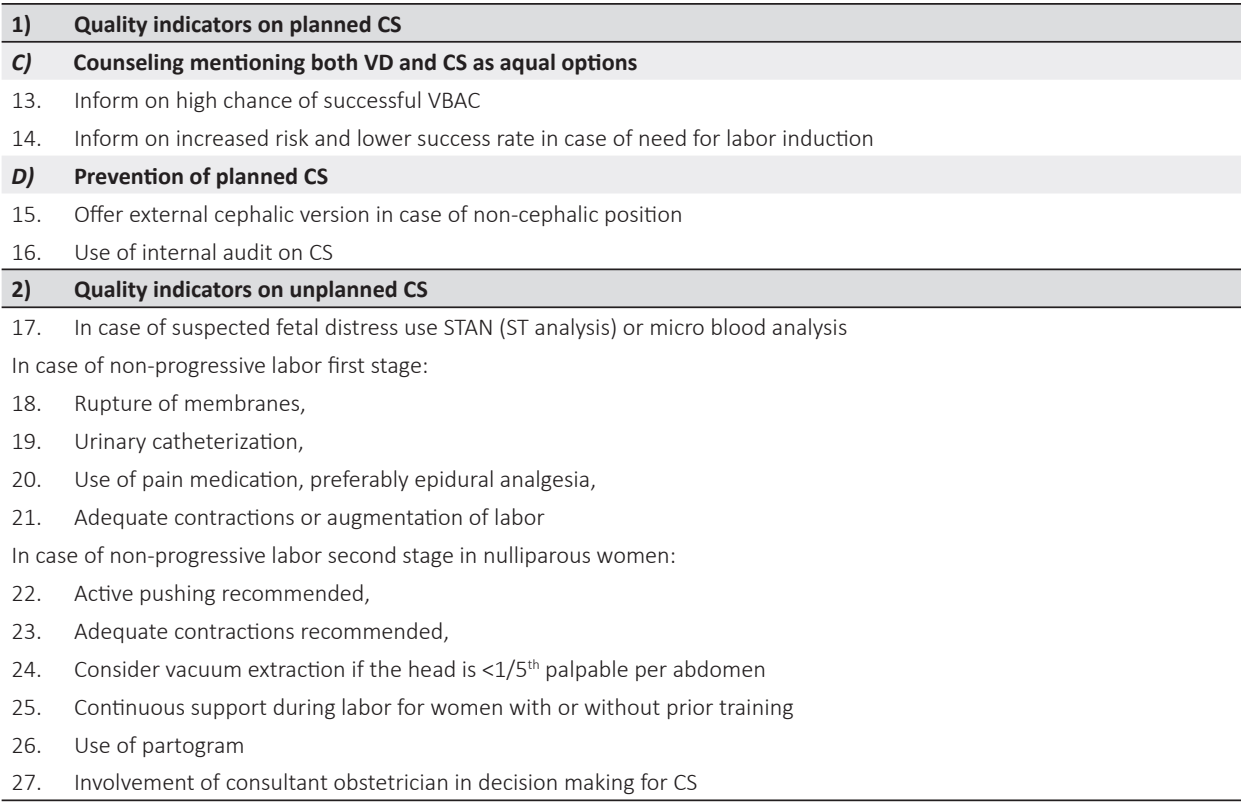


Table 2. Quality of care measured by CS quality indicator

\begin{tabular}{|c|c|c|c|}
\hline 1) & Quality indicators on planned CS & $\begin{array}{l}\text { Frequency of } \\
\text { occurrence }\end{array}$ & $\begin{array}{l}\text { Performance score } \\
\text { (adherence) }\end{array}$ \\
\hline A) & General counseling, CS is not mentioned (VD is the normal conduct) & & \\
\hline \multicolumn{2}{|r|}{ Twin pregnancy and first child cephalic position } & $1.3 \%$ & $16 \%$ \\
\hline \multicolumn{2}{|r|}{ Fetal macrosomia ( $<4.5 \mathrm{~kg}$ in maternal diabetes, $<5 \mathrm{~kg}$ no maternal diabetes) } & $4.3 \%$ & $33 \%$ \\
\hline \multicolumn{2}{|c|}{ Preterm labour, cephalic position } & $4.7 \%$ & $45 \%$ \\
\hline \multicolumn{2}{|r|}{ Small for gestational age without fetal distress } & $3.3 \%$ & $43 \%$ \\
\hline \multicolumn{2}{|r|}{ Previous shoulder dystocia without impaired perinatal outcome } & $1.1 \%$ & $22 \%$ \\
\hline \multicolumn{4}{|c|}{ Counseling directed at VD (VD and CS are options, VD is } \\
\hline \multicolumn{2}{|r|}{ Position of the placenta at $1-2 \mathrm{~cm}$ of the internal os } & $0.02 \%$ & $100 \%$ \\
\hline \multicolumn{2}{|c|}{ Request for CS without medical grounds: } & $1 \%$ & \\
\hline & Explore reason for request & & $80 \%$ \\
\hline • & Discuss (dis)advantages to CS delivery & & $66 \%$ \\
\hline • & In case of extreme fear: offer psychological counseling & & $62 \%$ \\
\hline \multicolumn{2}{|r|}{ Preterm breech delivery (frank, complete breech) } & $1.7 \%$ & $1.3 \%$ \\
\hline \multicolumn{4}{|c|}{ Counseling mentioning both VD and CS as equal options } \\
\hline \multicolumn{2}{|c|}{ Breech presentation at term } & $4.1 \%$ & $56 \%$ \\
\hline \multicolumn{2}{|r|}{ Previous CS (Inform on risks and chance for successful VBAC): } & $11.7 \%$ & $4 \%$ \\
\hline \multicolumn{2}{|r|}{$\begin{array}{l}\text { Previous CS and medical reason for induction of labour (inform on risks and chance } \\
\text { for successful VBAC) }\end{array}$} & $2.2 \%$ & $18 \%$ \\
\hline D) & Prevention of planned CS & & \\
\hline \multicolumn{2}{|r|}{ Offer external cephalic version in case of non-cephalic position } & $6 \%$ & $77 \%$ \\
\hline
\end{tabular}

Table 2 continued.

\begin{tabular}{|c|c|c|c|}
\hline 2) & Quality indicators on unplanned CS & $\begin{array}{c}\text { Frequency of } \\
\text { occurrence }\end{array}$ & $\begin{array}{c}\text { Performance score } \\
\text { (adherence) }\end{array}$ \\
\hline \multicolumn{2}{|r|}{ In case of suspected fetal distress use STAN (ST analysis) or micro blood analysis } & $16.9 \%$ & $46 \%$ \\
\hline \multicolumn{2}{|c|}{ In case of non-progressive labor first stage: } & $11.1 \%$ & \\
\hline • & Rupture of membranes & & $95 \%$ \\
\hline • & Urinary catheterization & & $61 \%$ \\
\hline • & Use of pain medication & & $78 \%$ \\
\hline • & Use of pain medication: epidural analgesia & & $49 \%$ \\
\hline • & Adequate contractions recommended & & $93 \%$ \\
\hline - & Before performing a CS, an optimal situation $(\mathrm{A}-\mathrm{E})>2 \mathrm{hrs}$ & & $23 \%$ \\
\hline - & Before performing a CS, an optimal situation $(\mathrm{A}-\mathrm{E})>4 \mathrm{hrs}$ & & $15 \%$ \\
\hline \multicolumn{2}{|r|}{ In case of non-progressive labor second stage in nulliparous women: } & $12.7 \%$ & \\
\hline • & Active pushing recommended, & & $98 \%$ \\
\hline - & Adequate contractions recommended, & & $72 \%$ \\
\hline • & Consider vacuum extraction if the head is $<1 / 5^{\text {th }}$ palpable per abdomen & & $45 \%$ \\
\hline \multicolumn{2}{|r|}{ Continuous support during labor for women with or without prior training } & $88.3 \%$ & $37 \%$ \\
\hline \multicolumn{2}{|c|}{ Use of partogram } & $6.9 \%$ & $54 \%$ \\
\hline
\end{tabular}




\section{$1 \quad$ Planned caesarean section}

Table 2 shows that for planned CS, the frequency of the occurrence of the specific events ranged from $0.02 \%$ to $11.7 \%$ and adequate care (performance scores) ranged from 4 to $100 \%$. Although in many obstetric situations caregivers do not follow guidelines, the impact on total caesarean section rate is not likely to change since the frequency of the situation is very low. This is the case for twin pregnancies with the first fetus in cephalic position, preterm breech and previous shoulder dystocia, occurring in less than $2 \%$ in the general population. The population with a high incidence and a low performance are women with a previous CS.

In an average obstetric population, $11.7 \%$ of all women have a previous CS and in only $15 \%$ counselling regarding estimated success rates of a VD, next to risks and benefits involved with CS and VD according to the guidelines was documented. In addition, in only $4 \%$ of the medical charts of these women, comments informing on risks and benefits were detailed. The highest performance scores for this group of women were found for mode of delivery counselling in case of placenta position at $1-2 \mathrm{~cm}$ of the internal os (100\%), to offer external cephalic version for non-cephalic position (77\%) and counselling on CS without medical grounds (62-80\%).

\section{Unplanned caesarean section}

Unlike the indicators for planned caesarean sections, the indicators for unplanned caesarean sections have a much higher frequency of occurrence, ranging from 11 to $88.3 \%$. In these indicators, guideline adherence in general is higher ranging from 23 to $98 \%$.

Continuous support during labor was advised for all women starting vaginal birth. In 37\% of these women the support was actually provided. It was advised to apply additional diagnostics such as ST-analysis or fetal scalp blood sampling to all women with suspected fetal distress, if this was technically possible and no contraindications existed to the procedure. In $46 \%$ of the women with suspected fetal distress, additional diagnostics were applied before proceeding to a CS. In women with non-progressive labour, the performance scores of the separate quality indicators (artificial rupture of membranes, urinary catheterization, use of pain medication (preferably epidural analgesia and adequate contractions), ranged from $61 \%$ to $95 \%$. However, the expert panel advised to proceed to a CS based on non-progression, not earlier than 2- 4 hours after all previous measures were fulfilled. Only in a small proportion of women, these criteria were met and in more than 77\% CS were performed too soon. 


\section{Discussion}

\section{Main findings}

This study resulted in a set of 27 evidence-based quality indicators on both planned as well as unplanned CS. Current care measurement in the Netherlands identified four major target groups for future implementation strategies due to their high prevalence and low adherence rate: improvement of counselling in women with a previous CS, improvement of implementation of continuous support during labour, additional diagnostics before proceeding to a CS in case of suspected fetal distress and allowing a longer waiting period before proceeding to a CS in case of non-progressive labour.

\section{Strengths and limitations}

Our study offers the first set of CS indicators covering entire obstetrical care, thereby enabling measurement of quality of obstetrical care in situations that exist antepartum (e.g. breech presentation), intrapartum (e.g. non-progressive labour) as well as postpartum (e.g. internal audit on CS). This is in contrast to previously developed indicators which only focussed on peripartum care [21]. We included 21 different types of hospitals in several regions in The Netherlands, analysing more than 1000 women per group in order to determine actual care. When comparing the data from our trial to data from the Foundation Perinatal Registration The Netherlands (PRN: the national obstetrical database), we find that the SC rate is comparable (22.2\% versus $23.4 \%$ ). With a similar distribution among planned and unplanned CS: $11.4 \%, 10.8 \%$ versus $10.5 \%, 12.9 \%$, respectively [22]. Thus, we expect our results to be a good representation of actual care in The Netherlands.

Although a standardised method for the development of quality indicators was used, there are several limitations to this study. To date no study compared the different methods used for quality indicator development. However, the RAND-modified Delphi method offers a systematic approach to indicator development and is a frequently used method that has proven to result in valid quality indicators [23]. In addition, one can challenge whether all quality indicators are usable and accepted in different and specific international obstetrical settings. However, the obstetrical situations described (previous CS, non-progressing labor, suspected fetal distress) are comparable world-wide and the basis of the quality indicators consists of recommendations derived from international guidelines and literature [15, 24]. Although there may be a different approach in obstetrical care in some cases (e.g. preterm breech delivery, fetal blood sampling), we expect a similar approach by most obstetrical healthcare professionals to the identified major categories. Therefore, we believe that the most important quality indicators are likely to be adopted by most obstetrical healthcare professionals internationally. 
The data collection from medical charts was performed by trained research nurses from the Dutch consortium, which could introduce bias. It was shown by Luck et al. that medical chart review somewhat underestimates the actual care given [25]. Not every detail of a consultation is noted in the medical chart. Secondly, despite the fact that trained research employees extracted the data, there might be interpretation bias. However, when considering the adherence percentages for the main categories (fetal distress, non-progressive labour and previous (S) in our study, we do not expect our results to change substantially.

\section{Interpretation}

In case of a rare situation like triplets, discussing the necessity of CS will only lead to marginal improvement of general care. However, an improvement strategy will have a considerably larger effect in case of a situation with a relatively high frequency and low adherence rate, such as non-progressive labour. The CS quality indicators allowed us to analyse obstetrical care in the Netherlands, thereby identifying groups of women in whom a high frequency of a certain quality indicator is observed in combination with low adherence. The next step in improvement of care will be to determine factors that influence the mode of delivery decision, by either facilitating or hindering quality indicator adherence. Based on these influencing factors, a tailor-made implementation strategy is expected to have a high impact on obstetrical care. It is essential to evaluate the effect of such a strategy on actual obstetrical care in terms of indicator adherence, CS rate, as well as maternal and neonatal outcome.

An analysis of data from the Consortium on Safe Labor by Boyle et al. showed that the most common indications for a primary CS in their US population were failure to progress $(35.4 \%)$ and non-reassuring fetal rate tracing (27.3\%) [24]. Furthermore, using the same data, Zhang et al found that the a repeat CS rate was a major contributor to the total CS rate $(30.9 \%)$ [15]. The target groups we identified are commonly mentioned indications for a CS globally, implying that our results are comparable to international data. Ample attention is paid to interventions that might increase trial of labour as well as vaginal birth after caesarean section $[26,27]$. There is increasing interest in the prevention of the primary CS, which means CS indications for the nulliparous single cephalic at term are an important factor: non-progressive labor and suspected fetal distress [24, 28, 29, 30]. Therefore, intervention in these groups are likely to have a high impact on current care internationally. The impact of an implementation strategy might vary internationally, depending on local CS rate, size of the target group and local barriers to optimal care. Countries with a high rate of elective repeat CS might benefit more from the same implementation strategy compared to countries with a relatively low CS rate. Not all interventions are applicable internationally.

In the United States for example, ST-analysis and fetal blood sampling are not practiced. 
However, these measures are indicators for good care in our study, and an uptake of these interventions might optimize care.

In general, the cost of a CS is about double that of a vaginal delivery [11]. After a first CS, a large majority of women have a CS in the subsequent pregnancy, ranging from 18 to $72 \%$ depending on the country women live in [31]. For each repeated CS, the morbidity increases, with higher risks of operative complications, blood transfusions, IC admittance and hysterectomy, adding extra costs [6-10]. Therefore, with on average one subsequent pregnancy, the extra costs are estimated to approach 7500 Euro. In Europe, 5.2 million women delivered in 2012, with on average a 30\% CS rate. With a reduction of 1\%, in Europe alone 390 million Euro can be saved. The WHO advocates a CS rate between 10-15\%, although this has been challenged. This would result in a cost reduction of 3.9 billion euro every year, with no likely harmful effect on maternal or neonatal outcomes.

Beside the use of the presented indicators for local improvement, a subset could be used for international comparison of CS care. Until now, interhospital and international comparison was directed at classification of CS rates, but this does not reflect quality of care $[14,15,16$, 32]. We believe that comparison of CS care could be directed at the subset of indicators that have the highest impact: 1 ) in women with a previous CS, structured information on risks and benefits on vaginal delivery compared to planned CS should be given and women should be given a choice; 2) women should be offered continuous support during vaginal delivery 3) before performing a CS for suspected fetal distress, fetal blood sampling or ST-analysis should be performed; 4) before performing a CS for non-progressive labour, a 2-4 hour waiting period should be installed after a situation with ruptured membranes, adequate contractions and adequate pain relief is established. Prior to applying this on an international basis, local current care should be established, as well as local facilitating and hindering factors.

\section{Conclusions}

This study provides a framework for future studies for improvement of guideline adherence and reduction of CS rates, thereby possibly improving the outcome for mother and child. Due to the relatively high frequency of occurrence in combination with a low adherence rate, we identified possible target groups where a tailor-made implementation strategy could improve CS care: offer continuous support during labour, women with a previous CS and women undergoing their primary CS for non-progressive labour or suspected fetal distress. The next step will be to identify barriers and facilitators that influence guideline adherence and incorporate them in an implementation strategy to improve care. 


\section{References}

1. Perinatal Care in The Netherlands 2012. Utrecht: Foundation Perinatal Registration The Netherlands (PRN), 2013

2. Information Centre. NHS maternity statistics, England: 2008-09. Department of Health, 2009.

3. Menacker F, Hamilton BE: Recent trends in cesarean delivery in the United States. NCHS Data Brief 2010;35:1-8.

4. Kwee A, Elferink-Stinkens PM, Reuwer PJHM, Bruinse HW. Trends in obstetric interventions in the Dutch obstetrical care system in the period 1993-2002. Eur J Obstet Gynecol Reprod Biol 2007;132:70-75.

5. World Health Organization. Appropriate technology for birth. Lancet 1985;2:436-7

6. Ananth CV, Smulian JC, Vintzileos AM. The association of placenta previa with a history of cesarean delivery and abortion: A meta-analysis. Am J Obstet Gynecol 1997;177:1071-1078.

7. Zwart JJ, Richters JM, Öry F, Vries de JIP, Bloemenkamp KWM, Roosmalen van J. Uterine rupture in the Netherlands: a nationwide population-based cohort study. BJOG 2009;116:1069-1080

8. Liu S, Liston RM, Joseph KS, Heaman M, Sauve R, Kramer MS, for the Maternal Health Study Group of the Canadian Perinatal Surveillance System. Maternal mortality and severe morbidity associated with low-risk planned caesarean delivery versus planned vaginal delivery at term. CMJH 2007;176:455-460.

9. Lumbiganon P, Laopaiboon M, Gülmezoglu AM, Souza JP, Taneepanichskul S, Ruyan P et al. World Health Organization Global Survey on Maternal and Perinatal Health Research Group: Method of delivery and pregnancy outcomes in Asia: the WHO global survey on maternal and perinatal health 2007-08. Lancet 2010;375:490-499.

10. Rossi AC, Lee RH, Chmait RH. Emergency postpartum hysterectomy for uncontrolled postpartum bleeding: a systematic review. Obstet Gynecol 2010;115:637-644.

11. NICE Clinical Guideline: Caesarean section. CG132. 23-11-2011.

12. Bragg F, Cromwell DA, Edozien LC, Gurol-Urganci I, Mahmood TA, Templeton A et al. Variation in rates of caesarean section among English NHS trusts after accounting for maternal and clinical risk: cross sectional study. BMJ 2010;341:C5065.

13. Menacker F, Declercq E, Macdorman MF. Cesarean delivery: background, trends, and epidemiology. Semin Perinatol 2006;30: 235-241.

14. Le Ray C, Blondel B, Prunet C, Khireddine I, Deneux-Tharaux C, Goffinet F. Stabilizing the caesarean section rate: which target population? BJOG 2014;DOI:10.1111/1471-0528.13199

15. Zhang J, Troendle J, Reddy UM, Laughon SK, Branch DW, Burkman R et al. Contemporary cesarean delivery practice in the United States. Am J Obstet Gynecol 2010;203:326.e1-10.

16. Brennan DJ, Murphy M, Robson MS, O’Herlihy C. The singleton, cephalic, nulliparous woman after 36 weeks of gestation: contribution to overall caesarean delivery rates. Obstet Gynecol 2011;117:273-279.

17. Grol R, Baker R, Moss F. Quality improvement research: understanding the science of change in health care. Qual Saf Health Care 2002;11:110-111.

18. Campbell SM, Braspenning J, Hutchinson A, Marshall MN. Research methods used in developing and applying quality indicators in primary care. BMJ 2003;326:816-819

19. Silverberg MJ, Thorsen P, Lindeberg H, Grant LA, Shah KV. Condyloma in pregnancy is strongly predictive of juvenileonset recurrent respiratory papillomatosis. Obstet Gynecol 2003;101:645-652.

20. Robson MS, Scudamore IW, Walsh SM. Using the medical audit to reduce cesarean section rates. Obstet Gynecol 
1996;174:199-205.

21. Kesmodel US, Jølving LR. Measuring and improving quality in obstetrics-the implementation of national indicators in Denmark. Acta Obstet Gynecol Scand 2011;90:295-304.

22. Perinatal Care in The Netherlands 2010. Utrecht: Foundation Perinatal Registration The Netherlands (PRN), 2013.

23. Kötter T, Eva Blozik E, Scherer M. Methods for the guideline-based development of quality indicators-a systematic review. Impl Science 2012;7:21.

24. Boyle A, Reddy UM, Landy HJ, Huang CC, Laughon SK. Primary caesarean delivery in the United States. Obstet Gynecol 2013;122:33-40.

25. Luck J, Peabody JW, Dresselhaus TR, Lee M, Glassman P. How well does chart abstraction measure quality? A prospective comparison of standardized patients with the medical record. Am J Med 2000;108:642-9.

26. Lundgren I, Smith V, Nilsson C, Vehvilainen-Julkunen K, Nicoletti J, Devane D, Bernloehr A, van Limbeek E, Lalor J, Begley C. Clinician-centred interventions to increase vaginal birth after caesarean section (VBAC): a systematic review. BMC Pregnancy Childbirth 2015;15:16.

27. Dexter SC, Watkinson SJ. Meeting the challenge of maternal choice in mode of delivery with vaginal birth after caesarean section: a medical, legal and ethical commentary. BJOG 2014;121:133-140.

28. American College of Obstetricians and Gynecologists (College); Society for Maternal-Fetal Medicine, Caughey AB, Cahill AG, Guise JM, Rouse DJ. Safe prevention of the primary cesarean delivery. Am J Obstet Gynecol 2014;210:179-93.

29. Delbaere I, Cammu H, Martens E, Tency I, Martens G, Temmerman M. Limiting the caesarean section rate in low risk pregnancies is key to lowering the trend of increased abdominal deliveries: an observational study. BMC Pregnancy Childbirth 2012;12:3.

30. Haerskjold A, Hegaard HK, Kjaergaard H. Emergency caesarean section in low risk nulliparous women. J Obstet Gynaecol 2012;32:543-7.

31. Guise JM, Eden K, Emeis C, Denman MA, Marshall N, Fu RR et al. Vaginal birth after cesarean: new insights. Evid Rep Technol Asses 2010;191:1-397.

32. Robson MS. Can we reduce the caesarean section rate? Best Pract Res Clin Obstet Gynaecol 2001;15:179-94. 


\section{Appendix - Stepwise procedure of CS quality indicator development}

\section{Methods}

The method of indicator development was carried out according to four consecutive steps: 1) identification of recommendations, 2) questionnaire round, 3) consensus meeting and 4) critical evaluation and operationalization.

\section{Step 1: Identification of recommendations}

Five international guidelines were used to extract recommendations: guidelines of the ACOG $(n=1), \operatorname{RCOG}(n=3)$ and SOGC $(n=1)$. In addition, all national guidelines of the Dutch Society of Obstetricians and Gynaecologists (NVOG) with recommendations that may affect CS rates were used (e.g. fetal surveillance during labor, breech presentation, twin pregnancy etc.). Furthermore, the guideline on antiretroviral therapy by the CBO (Centraal BegeleidingsOrgaan), a Dutch organization aiming at improving the quality of care by health care professionals, was selected. In addition, the articles of Silverberg et al. and Robson et al. were used for their information on condyloma treatment in pregnancy and medical audit to reduce $\mathrm{CS}$ rates, respectively. ${ }^{[14,15]}$

Subsequently, the recommendations were categorised as follows: 1) planned CS (including recommendations on counselling on vaginal delivery (VD) versus caesarean section (CS) in different situations and prevention of planned CS) 2) unplanned CS. The recommendations considering counselling include situations in which a) general counselling is advised without mentioning the possibility of choosing CS (VD is the normal conduct); b) counselling is advised directed at VD (VD and CS are both options but VD is preferable; c) counselling is advised mentioning both VD and CS as equal options; and d) planned CS is advised.

\section{Step 2: Questionnaire round}

The identified recommendations were subdivided according to the abovementioned categories and were transformed into a questionnaire that was sent to the expert panel. If available, the questionnaire contained the evidence level per recommendation in order to support the decision-making process. The experts were asked to rate each recommendation on a nine-point Likert scale with respect to their value for both health gain and overall efficacy. In order to be able to distinguish between recommendations with a high score on the Likert scale, a ranking of recommendations per category was used. Furthermore, the experts were requested to add complementary recommendations. This part of the procedure resulted in an allocation of the recommendations for the consensus meeting into recommendations with high, uncertain or low potential as quality indicator. 
Recommendations were considered 'high potential' if: 1) the median rating of the recommendation was 8 or more; 2) the recommendation was in the top ranking of the specific category and had at least $20 \%$ of the maximum score and 3) $70 \%$ or more of the expert panel ratings were in the highest tertile on the Likert scale $(7,8$ or 9$)$. There were three possible appraisal combinations that rated the recommendation as 'uncertain potential': 1) a median score of 8 or more and a top ranking for less than $20 \%$ of the maximum score; 2 ) a median score less than 8 and a ranking for at least $20 \%$ of the maximum score or 3 ) a rating of $30 \%$ or more in the highest $(7,8$ or 9$)$ and lowest tertile $(1,2$ or 3$)$ on the Likert scale (=disagreement). The recommendation was determined to have 'low potential' if none of the abovementioned criteria were applicable. ${ }^{[16]}$

\section{Step 3: Consensus meeting}

In a face-to-face consensus meeting the results of the questionnaire round were discussed. In order to improve the debate each expert was provided with the overall results from the questionnaire round, as well as their own ratings and additional remarks. Firstly, the experts were asked if they agreed that the recommendations marked 'high potential' indeed had to be selected as potential quality indicators to assess and monitor quality of care, and whether or not they could agree to the dismissal of those recommendations considered 'low potential' as quality indicators. In addition, the experts were requested if there were any recommendations marked as 'uncertain potential' they would strongly advise to consider as an indicator. The members of the expert panel were finally asked which additional recommendations proposed by an expert would be suitable as quality indicator.

\section{Step 4: Critical evaluation and operationalization}

After the consensus meeting the results were offered to all the members of the expert panel for final approval. Subsequently, the selected recommendations were translated into indicators by defining numerators and denominators, i.e. the number of women in whom a certain test or intervention should have been performed and has been performed, divided by the number of women in whom a certain test or intervention should have been performed. Using this method, an adherence percentage could be calculated in order to assess current care.

\section{Results}

\section{Step 1: Identification of recommendations}

In the first step, 51 recommendations on CS were identified: 16 situations where VD was the preferred mode of delivery (category 1a and 1b); 9 situations in which counselling was advised on the possibility of choosing either vaginal or caesarean delivery (category 1c); 2 recommendations on prevention of planned CS (category 1d), and 14 situations where planned CS was advised. Furthermore, there were 8 recommendations on unplanned CS. 


\section{Step 2: Questionnaire round}

The 17 experts each received a questionnaire, of which 16 were returned ( 2 non-responders, $94 \%$ response rate). Out of the 51 recommendations, 14 had 'high potential', 18 had 'uncertain potential' and 19 had 'low potential'. The experts suggested 5 additional recommendations.

\section{Step 3: Consensus meeting}

Eight experts attended the consensus meeting (47\%), 5 obstetricians and 3 midwives. This meeting resulted in a consensus-based set of 27 key recommendations labelled according to two categories [See Table 1]. Category 1 comprised 14 recommendations on mode of delivery counselling: 1a) general counselling is advised without mentioning the possibility of choosing CS (VD is the normal conduct) $(N=5) ; 1 b)$ counselling is advised directed at VD (VD and CS are both options but VD is preferable) $(N=5), 1 c)$ counselling is advised mentioning both VD and $\mathrm{CS}$ as equal options $(\mathrm{N}=4)$. There were 2 recommendations on prevention of planned CS (1d). The experts approved of 11 recommendations on the prevention of unplanned CS (category 2).

With regard to the situations were planned CS was advised (category $1 \mathrm{~d}$ ), the 12 indications were not considered to be of high potential for measuring quality of care. For example, in case of placenta praevia, it is not likely that an obstetrician would proceed with VD. Consequently, it is not expected that adherence to such an indicator would be low, and improvement of care would be necessary.

\section{Step 4: Critical evaluation, operationalization and final approval}

The 27 key recommendations were sent to the expert panel for final approval, which was obtained from 16 experts; there was 1 non-responder. Finally, the selected recommendations were translated into indicators by defining numerators and denominators: i.e. the number of women in whom a certain intervention or counselling method should have been performed and has been performed, divided by the number of women in whom a certain intervention or counselling method should have been performed.

For example: one of the indicators states that in case of breech presentation after 34 weeks, external cephalic version should be offered. Guideline adherence then is measured by dividing the number of women in the study group with a fetus in breech presentation after 34 weeks in whom external cephalic version is offered by the total number of women with a fetus in breech presentation after 34 weeks.

This stepwise procedure resulted in a set of 27 CS quality indicators, including 16 indicators on planned CS as well as 11 indicators on unplanned CS (Table S1). The process of development 
of quality indicators on CS by using the RAND-modified Delphi method is depicted in Figure 1 , the final indicator set is given in Table 2 .

\section{Table S1. Quality indicators on planned CS}

Planned CS is advised:
Suspected placental abruption and viable fetus
Vasa praevia
Placenta praevia
Placenta localization less than $1 \mathrm{~cm}$ from the internal os
Relevant scar in the uterus (e.g. vertical incision during previous CS)
Monoamniotic twin pregnancy
Breech presentation at term and maternal pelvic abnormality
Breech presentation at term and previous non-progressive labor
First genital herpes outbreak in the third trimester of pregnancy
Impossible vaginal birth (e.g. due to cervical myomas, congenital malformations)
Uterine rupture in previous pregnancy
Persistent transverse presentation, despite external cephalic version




\section{Identification of barriers and facilitators for optimal cesarean section care: perspective of professionals}

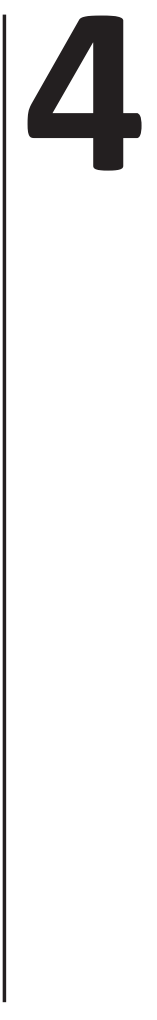

Sonja Melman, Rachel Hellen Petra Schreurs, Carmen Desiree Dirksen, Anneke Kwee, Jan G Nijhuis, Nicol Anna Cornelia Smeets, Hubertina Catharina Johanna Scheepers, Rosella Petronella Maria Gemma Hermens. 


\section{Abstract}

\section{Introduction}

The cesarean section (CS) rate has increased over recent decades with poor guideline adherence as a possible cause. The objective of this study was to explore barriers and facilitators for delivering optimal care as described in clinical practice guidelines.

\section{Material and methods}

Key recommendations from evidence-based guidelines were used as a base to explore barriers and facilitators for delivering optimal CS care in The Netherlands. Both focus group and telephone interviews among 29 different obstetrical professionals were performed. Transcripts from the interviews were analysed. Barriers and facilitators were identified and categorised in six domains according to the framework developed by Grol: the guideline recommendations (I), the professional (II), the patient (III), the social context (IV), the organizational context ( $\mathrm{V}$ ) and the financial/legislation context (VI).

\section{Results}

Most barriers were found in the professional and organizational domain. Barriers mentioned by healthcare professionals were disagreement with specific guideline recommendations and hesitation to allow women to be part of the decision making process. Other barriers are lack of adequately trained personal staff, lack of collaboration between professionals and lack of technical equipment.

\section{Conclusions}

Clear facilitators and barriers for guideline adherence were identified in all domains. Several barriers may be addressed by using decision aids on mode of delivery or prediction models to individualise care in women in whom both planned vaginal delivery and CS are equal options. In women with an intended vaginal delivery, adequate staffing and the availability of both fetal blood sampling and epidural analgesia are important. 


\section{Introduction}

The cesarean section (CS) rate has increased over recent decades in both developed and developing countries. The World Health Organization has targeted the CS rate to be $10 \%$ to $15 \%$, although this low rate has recently been questioned $(1,2)$. In The Netherlands, the CS rate has increased steadily over the past decade from $10.8 \%$ in 1999 to $16.5 \%$ in $2014(3,4)$. In absolute numbers, the most impressive rise was documented among healthy women with a singleton in vertex position between 37 and 42 weeks gestation (5). Furthermore, in The Netherlands in 2013, a large variation in vaginal delivery rates per hospital were observed in the nulliparous term singleton vertex group, with rates ranging from 45.1-73.2\% (6).

This worldwide increasing CS rate is cause for concern since this will lead to increased maternal and neonatal complications, increased risks for future pregnancies, and increased healthcare costs (7-10). Literature mainly focusses on individual-level explanations for the CS rise, including increased maternal age, technological innovation, women's choice or clinical risk factors such as obesity and previous CS. However, these explanations do not account for the majority of the variation observed (11).

In order to optimize CS practice, the Royal College of Obstetricians and Gynecologists developed an evidence-based guideline with clear recommendations that have a direct effect on the decision to perform a CS (12). In the caesarean section implementation study (SIMPLE), a RAND-modified Delphi procedure resulted in 27 quality indicators describing optimal CS care based on international guidelines and literature (13). The adherence to CS quality indicators was measured in 21 hospitals in The Netherlands in order to gain insight into current obstetrical care.

Besides insight into optimal and current care, insight into facilitators and barriers among all professionals involved in CS decision-making is essential. This insight can support the development of a tailored strategy to overcome barriers and improve guideline implementation. The present qualitative study explored facilitators and barriers for optimal CS care among midwives, obstetrical residents and obstetricians.

\section{Material and methods}

\section{Design}

A qualitative study was conducted in 2011 to determine facilitators and barriers that influence the decision to perform a CS from a healthcare professionals' perspective. Two separate 
focus group interviews were performed; one with obstetricians and one with obstetrical residents from different regions and different types of hospitals in The Netherlands. Due to organizational difficulties a focus group among independent midwives could not be arranged. Therefore, we conducted telephone interviews among nine midwives until data saturation was reached (the last interview did not reveal any new information).

\section{Setting}

Currently in The Netherlands, pregnant women without medical complications are supervised by a registered midwife (primary care) and have the possibility to choose where to give birth (at home or in an outpatient hospital setting). If medical complications exist or develop during pregnancy or delivery, the attending midwife refers the pregnant woman to an obstetrician in a hospital (secondary care). Certain obstetric situations may lead to an advise to deliver by planned CS, whereas others may lead to the need for counselling on risks and benefits of a planned vaginal delivery opposed to a planned CS. Mode of delivery counselling is mostly performed by obstetricians and residents. Therefore, all situations that may lead to a planned CS are the responsibility of secondary care. However, referring midwifes may provide their opinion before referral and are often consulted by the women for second opinion and are therefore an influencing factor.

\section{Study population}

Thirty obstetricians and residents from university and non-university hospitals in different regions of The Netherlands were invited to participate to focus group interviews. The obstetricians and residents were all members of the Dutch Society of Obstetrics and Gynaecology. The midwives were invited based on recommendations from the Dutch National Association of Midwifery and worked in primary or secondary care.

The Medical Ethical Committee (CMO) of Maastricht (azM/UM) declared that no ethical approval was necessary for this study protocol (09-4-047), since it is not considered a study according to the Medical Research Involving Human Subjects Act (WMO: Wet medischwetenschappelijk onderzoek met mensen).

\section{Development interview guide and data collection}

Quality indicators from the SIMPLE study (based on key recommendations on CS care, abstracted from guidelines of the Royal College of Obstetricians and Gynaecologists, the American Congress of Obstetricians and Gynecologists, the Dutch Society of Obstetrics and Gynaecology and the Society of Obstetricians and Gynaecologists of Canada) were used as a base for exploration of barriers and facilitators (Table S1, appendix) (13). These quality indicators considered mode of delivery counselling, planned CS and prevention 
of (emergency) CS, and were discussed separately during the interviews. Facilitators and barriers were explored at different domains, based on the model developed by Grol (14-15) concerning the guideline recommendations itself (domain I), the professional (domain II), the patient (domain III), the social domain (domain IV), the organizational domain (domain $\mathrm{V})$ and the financial/legislation domain (domain VI). The focus group interview among obstetricians was moderated by a project member (obstetrician). The focus group interview among residents was moderated by another project member (resident). Individual telephone interviews among midwives were conducted by the same resident.

\section{Statistical analysis}

The interviews were fully transcribed and analysed using the qualitative analysis tool of ATLAS.ti GmbH Version 7 (Berlin, Germany). Two reviewers (SM and RS) independently read the interviews and coded facilitators and barriers for each of the recommendations and transcripts. The identified factors were assigned to the appropriate domains. Disagreements were resolved by discussion between the reviewers. If there was no consensus, a third independent reviewer was consulted (RH).

\section{Results}

The obstetricians worked at non-university non-teaching hospitals $(\mathrm{N}=6)$ or non-university teaching hospitals $(\mathrm{N}=4)$. Five residents from a non-university hospital, and five residents from a university hospital were included. The midwives worked either in a private practice $(\mathrm{N}=5)$ (rural and urban areas), non-university hospital $(\mathrm{N}=3)$ or university hospital $(\mathrm{N}=2)$. A total of 38 barriers and 11 facilitators were identified (Table S2, appendix), which mainly concerned the professional and organizational domain, described in detail hereinafter.

\section{Domain I: The CS guideline recommendations}

All types of professionals mentioned that guidelines do not adequately consider individual patient characteristics that might influence guideline adherence. As one of the obstetricians described:

If the woman is a nullipara, pregnant with a child that is expected to be large for gestational age and with a fetal head not engaged at term, it depends on her characteristics whether or not I will discuss a CS'.

This barrier mainly applies to guidelines aiming at vaginal birth in specific situations, such as fetal macrosomia, labour dystocia, breech presentation and previous shoulder dystocia. 
Furthermore, obstetricians mentioned that guidelines were not easily available on the professional website, whereas residents noted that local protocols were not always recently updated.

Furthermore, not all professionals agreed with guideline recommendations. Almost all types of professionals disagreed with the recommendation: 'A CS should not be mentioned in case of a previously experienced shoulder dystocia if there is no residual neonatal damage'. The decision to offer a CS mainly depends on the severity of the previous shoulder dystocia, and not on residual neonatal damage alone.

\section{Domain II: The professional domain}

Obstetricians and residents mentioned unclear documentation on previous deliveries, including advice on mode of delivery in future pregnancies, as an important barrier for guideline adherence. Furthermore, they stated that incomplete counselling or unclear documentation of the decision making process for mode of delivery in the current pregnancy, is an important factor for acting in line with the agreed mode of delivery. For example:

You have planned a CS for a woman with a history of fetal macrosomia (4500 grams) and shoulder dystocia. If labour starts prematurely, you might advise her to undergo a vaginal delivery, since the expected fetal weight is probably less than 4000 grams'.

Lack of experience regarding clinical skills in daily practice was also mentioned among all types of professionals to affect guideline adherence, mainly concerning vaginal breech deliveries, fetal scalp blood sampling and external cephalic version. The mode of delivery will largely depend on the attending obstetrician.

Another barrier mentioned by the residents regarding the use of fetal scalp blood sampling is the large variation in policy between obstetricians as well as between hospitals. Some obstetricians favour a vacuum extraction when full dilatation of the cervix is reached, whereas others would prepare for fetal scalp blood sampling in order to, possibly, avoid operational vaginal delivery.

Obstetricians mentioned that the ability to assess the cardiotocogram remotely as facilitator for optimal care, since this improves communication between the obstetrician on call and the resident without the necessity to be present at the delivery ward. 


\section{Domain III: The patient context}

A barrier mentioned by obstetricians and residents is mode of delivery advice by friends or family of a pregnant woman. Particularly negative experiences regarding the outcome of the neonate are perceived to be cause of anxiety and reduced cooperation of a pregnant woman, which can complicate communication between a pregnant woman and her caregiver.

Another barrier mentioned by obstetricians is that they feel it might be difficult for women to adequately balance current and future fetal risks, next to maternal risks and benefits in choosing mode of delivery.

'Counselling in pregnancy is fundamentally different, since it concerns the mother but also her child. Women seem more concerned for their current child than for a possible future pregnancy. Sometimes weighing the risks of a vaginal birth after previous CS, also considering future pregnancies, is even difficult for healthcare providers'.

\section{Domain IV: The social context}

All types of professionals mentioned troublesome collaboration as a barrier. Some residents might hesitate to call the anaesthesiologist, especially at night. As one of the residents described:

In our hospital, the residents are not allowed to independently consult the anaesthesiologist at night. We first have to call the obstetrician, and he or she has to consult the anaesthesiologist. It is a barrier for providing epidural anaesthesia at night.'

Clear agreements on availability of epidural analgesia are mentioned to be a facilitator in this situation.

The residents and midwives mentioned the presence of a strict hierarchy and wide variation in obstetrical policy between obstetricians as barriers for collaboration. The hierarchy causes some residents and midwives to be reluctant in providing feedback on a decision. An open attitude is essential in an obstetrical team. Residents add that the decision to perform a CS for non-progressing labour might also depend on the time (evening or night). 


\section{Domain V: The organizational context}

Some barriers are specifically related to the Dutch obstetrical care system. All types of professionals mentioned there are no general agreements on the responsibility for mode of delivery counselling. Some obstetricians feel they should be responsible for mode of delivery counselling. One of the midwives described:

'Obstetricians are sometimes even angry that we already performed the mode of delivery counselling and that the pregnant woman chose her mode of delivery.'

In women with a previous CS, obstetricians and residents stated that, although a consultation in secondary care is preferred before 20 weeks of pregnancy, the current habit of referral to secondary care at 36 weeks of pregnancy seems too late for an adequate shared decision making process on mode of delivery. Women are often already fully focussed on a particular mode of delivery, which makes counselling by an obstetrician more difficult. Protocols for cooperation between first and secondary care, considering mode of delivery counselling, as well as timing of referral, would facilitate optimal care.

Considering the use of additional diagnostics for evaluating the fetal condition during labour, prior to performing a CS for suspected fetal distress, there are several barriers perceived by residents and midwives. Fetal scalp blood sampling might be limited due to technical limitations during sample collection or sample assessment in laboratories. The procedure seems time consuming and often needs to be repeated. One of the residents adds:

'At first, we had to send the collected blood samples to the laboratory. After they bought a new device, approximately 3 out of 4 samples could not be analysed. You do not wish to experience that.'

\section{Domain VI: The financial/ legislation domain}

Finally, it was mentioned by all professionals that there is insufficient staffing and monetary compensation in order to provide continuous support for women during labour. 


\section{Discussion}

\section{Main findings}

In order to improve CS care, a high level of adherence to evidence based clinical guidelines is required. We conducted a qualitative study to determine which factors influence the adherence to recommendations that have a direct effect on the decision to perform a CS. Among professionals, we identified 11 main facilitators and 38 main barriers for optimal care to previously developed quality indicators on mode of delivery counselling, planned CS and prevention of CS (13).

In our study on actual care, the groups of women with highest expected impact on improvement of care concerned women with a previous CS, and nulliparous women in whom continuous support was not always given, in whom an unplanned CS is performed for suspected fetal distress without applying additional diagnostics (ST-analysis or fetal scalp blood sampling), or in whom an unplanned CS is performed for non-progressing labour without adequate waiting period (2-4 hours).

Regarding counselling women with a previous CS, professionals hesitate to allow women to be part of the decision making process, since they fear women are not equipped to decide on mode of delivery when balancing risks and benefits for both their own health, that of their baby and a possible future pregnancy. A main facilitator for obstetricians and residents was detailed mode of delivery counselling and clear documentation of the decision making process for mode of delivery, emphasizing the importance of adequately describing the counselling process and also to discuss exceptions or conditions to the agreed mode of delivery. Structured counselling using decision aids can help to address women's anxiety and when the content of this counselling is agreed upon by both first and second line healthcare providers, variation in care between different healthcare providers is likely to reduce. Using prediction models may help to individualise care.

Regarding unplanned CS in nulliparous women, the Dutch ministry of Health supports continuous support during labour, although this is not guaranteed in every day practice. Furthermore, 24/7 availability of epidural analgesia is agreed upon, however this is not always implemented. The remarks stating that timing of a CS is partially based on the time of day suggests that availability of different healthcare providers is a clear barriere.

\section{Interpretation}

The present study is, to our knowledge, the first to analyse facilitators and barriers for optimal CS care with international guidelines as a basis. Chaillet et al. studied the implementation of 
guidelines on vaginal birth after CS in Quebec, Canada. They concluded that adoption of guidelines may be improved if local healthcare professionals' perceptions are considered (16). In line with our study, others identified availability of equipment and staff, skill levels, acceptance of guidelines and women's motivations to be of influence $(16,17)$.

There are however, some factors that can be explained by cultural differences or local habits, for example economical, political or medico-legal concerns. In the study by Chaillet et al., obstetricians mentioned medico-legal concerns on several occasions as a barrier for optimal care (16). This is not in line with our findings, probably due to differences in medico-legal habits. The study of Yazdizadeh et al., revealed several barriers regarding the economic and political domain, which may be explained by a differently regulated healthcare system in Iran (17).

The unique structure of the Dutch obstetrical care system entails several challenges for health care providers in terms of continuity of care, referral of pregnant women and responsibility of care. When considering the Dutch healthcare system, improved collaboration between midwives and obstetricians seems an important step in improvement of care.

\section{Strengths and limitations}

As framework for the interviews, we used recommendations derived from evidence based guidelines on CS care, as described in the SIMPLE study (13). Barriers and facilitators were explored for those factors that are considered as most important for measuring optimal CS care.

We invited different types of obstetric healthcare providers that might have an influence on the offered CS care to participate to this qualitative study: obstetricians, residents and midwives, respectively. Professionals from different types of hospitals and private practices from different Dutch regions participated to this study, thereby representing all different elements of Dutch obstetrical care. The different types of healthcare providers were interviewed separately, in order to let them speak without restraint. The main barriers and facilitators were frequently mentioned among all different types of professionals, suggesting that the identified barriers are useful for the development of a new implementation strategy. Although a standardized method for the identification of barriers and facilitators was used, there are some limitations to this study. First, the analysis of the interviews is prone to interpretation bias. In order to reduce this bias, all interviews were interpreted by two independent reviewers, based on the theoretical model by Grol $(14,15)$. 
Since the influencing factors were identified using a qualitative, explorative method, no quantitative conclusions can be justified by this method. Finally, this study is performed in a national setting. The interviews were based on previously developed quality indicators, derived from national and international guidelines. We identified some facilitators and barriers that are typical for the Dutch system, concerning the collaboration between first and secondary care: for example the responsibility for mode of delivery counselling and barriers relating to the timing of referral from midwife to obstetrician. It is, however, in line with literature that there are barriers specific to regional habits and practice $(16,17)$. With international guidelines as a basis, we consider most results to be potentially relevant for international use, since our results describe the availability of equipment and staff, acceptance of guidelines and women's motivations to be of influence in line with literature.

\section{Conclusion}

In conclusion, clear facilitators as well as barriers for guideline adherence were identified at all domains, yet particularly on professional and organizational domain. During implementation of CS guidelines, professionals should be aware of the identified barriers and facilitators and take these into account. 


\section{References}

1. World Health Organization. Appropriate technology for birth. Lancet. 1985;2:436-437.

2. D'Alton ME, Hehir MP. Cesarean delivery rates revisiting a 3-Decades-Old Dogma. JAMA 2015;314:2238-2240.

3. 10 Years perinatal registration in The Netherlands, 1999-2008. Utrecht: Foundation Perined The Netherlands, 2011

4. Perinatal care in The Netherlands 2014. Utrecht: Foundation Perined The Netherlands, 2013

5. The result counts hospitals. 2012. Health Care Inspectorate (IGZ) Netherlands, Ministry of Health, Welfare and Sport.

6. Kwee A, Elferink-Stinkens PM, Reuwer PJ, Bruinse HW. Trends in obstetric interventions in the Dutch obstetrical care system in the period 1993-2002. Eur J Obstet Gynecol and Reprod Biol 2007;132:70-75.

7. Deneux-Tharaux C, Carmona E, Bouvier-Colle MH, Breart G. Postpartum maternal mortality and cesarean delivery. Obstet Gynecol 2006;108:541-548.

8. Shorten A. Maternal and neonatal effects of caesarean section. BMJ 2007;335:1003-1004.

9. Yang Q, Wen SW, Oppenheimer L, Chen XK, Black D, Gao J, et al. Association of caesarean delivery for first birth with placenta praevia and placental abruption in second pregnancy. BJOG 2007;114:609-613.

10. Heer IM, Kahlert S, Rummel S, Kumper C, Jonat W, Strauss A. Hospital treatment - Is it affordable? A structured cost analysis of vaginal deliveries and planned caesarean sections. Eur J Med Res 2009;14:502-506.

11. Bragg F, Cromwell DA, Edozien LC, Gurol-Urganci I, Mahmood TA, Templeton A et al. Variation in rates of caesarean section among English NHS trusts after accounting for maternal and clinical risk: cross sectional study. BMJ 2010;341:c5065.

12. NICE Clinical Guideline: Caesarean section. CG132. 23-11-2011.

13. Melman S, Schoorel ECN, De Boer K, Burggraaf H, Derks JB, Van Dijk D et al. Development and measurement of guidelines-based quality indicators of caesarean section care in the Netherlands: a RAND-modified Delphi procedure and retrospective medical chart review. PlosOne 2016: 11:e0145771. Doi:10.1371/journal.pone.0145771.

14. Grol R. Beliefs and evidence in changing clinical practice. BMJ. 1997;315:418-421.

15. Grol R. Improving the quality of medical care: building bridges among professional pride, payer profit, and patient satisfaction. JAMA 2001;286:2578-2585.

16. Chaillet N, Dube E, Dugas M, Francoeur D, Dube J, Gagnon S et al. Identifying barriers and facilitators towards implementing guidelines to reduce caesarean section rates in Quebec. Bulletin of the World Health Organization 2007;85:791-797.

17. Yazdizadeh B, Nedjat S, Mohammad K, Rashidian A, Changizi N, Majdzadeh R. Cesarean section rate in Iran, multidimensional approaches for behavioral change of providers: a qualitative study. BMC Health Serv Res 2011;11:159. 


\section{Appendix}

Table S1. Set of CS quality indicators

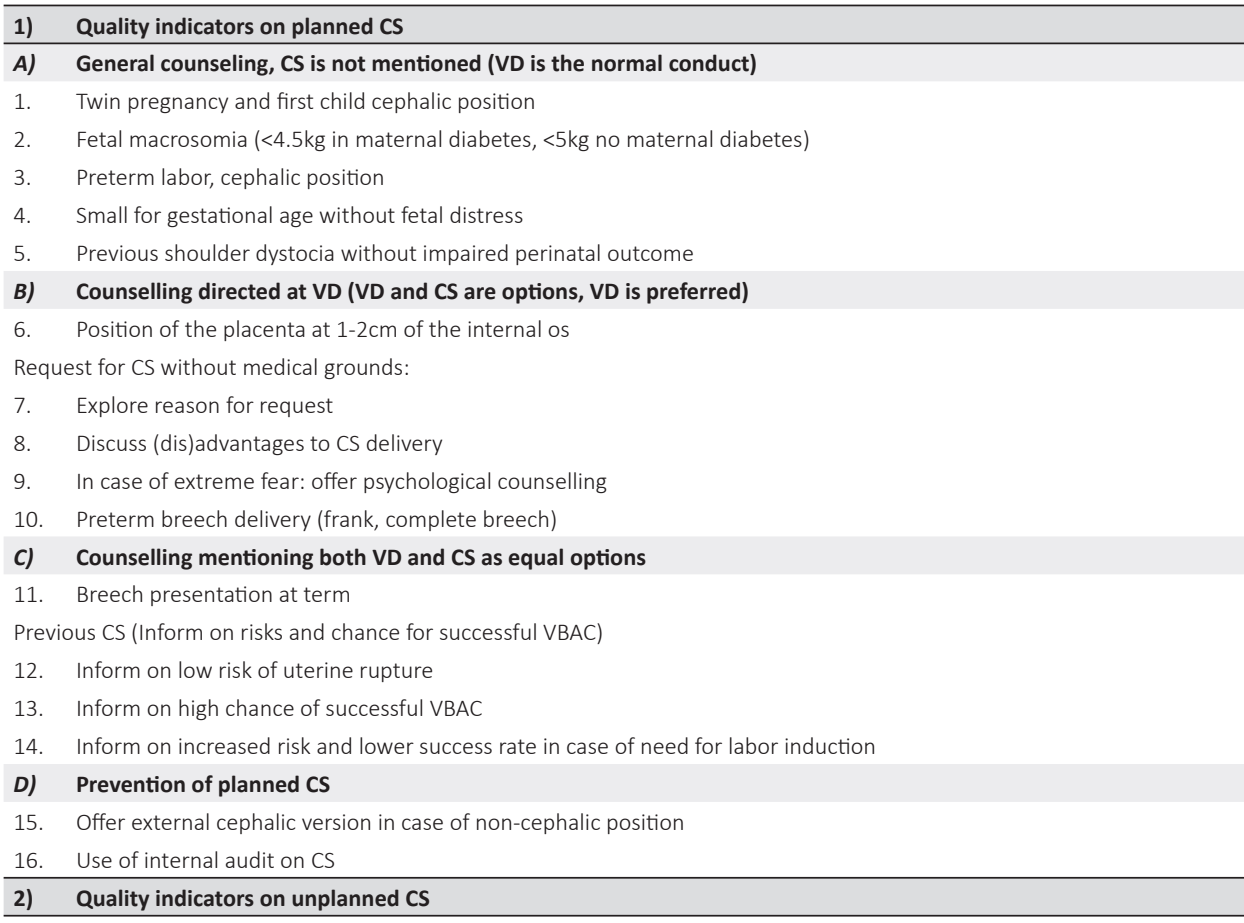

17. In case of suspected fetal distress use STAN (ST analysis) or micro blood analysis

In case of non-progressive labor first stage:

18. Rupture of membranes,

19. Urinary catheterization,

20. Use of pain medication, preferably epidural analgesia,

21. Adequate contractions or augmentation of labor

In case of non-progressive labor second stage in nulliparous women:

22. Active pushing recommended,

23. Adequate contractions recommended,

24. Consider vacuum extraction if the head is $<1 / 5^{\text {th }}$ palpable per abdomen

25. Continuous support during labor for women with or without prior training

26. Use of partogram

27. Involvement of consultant obstetrician in decision making for CS 


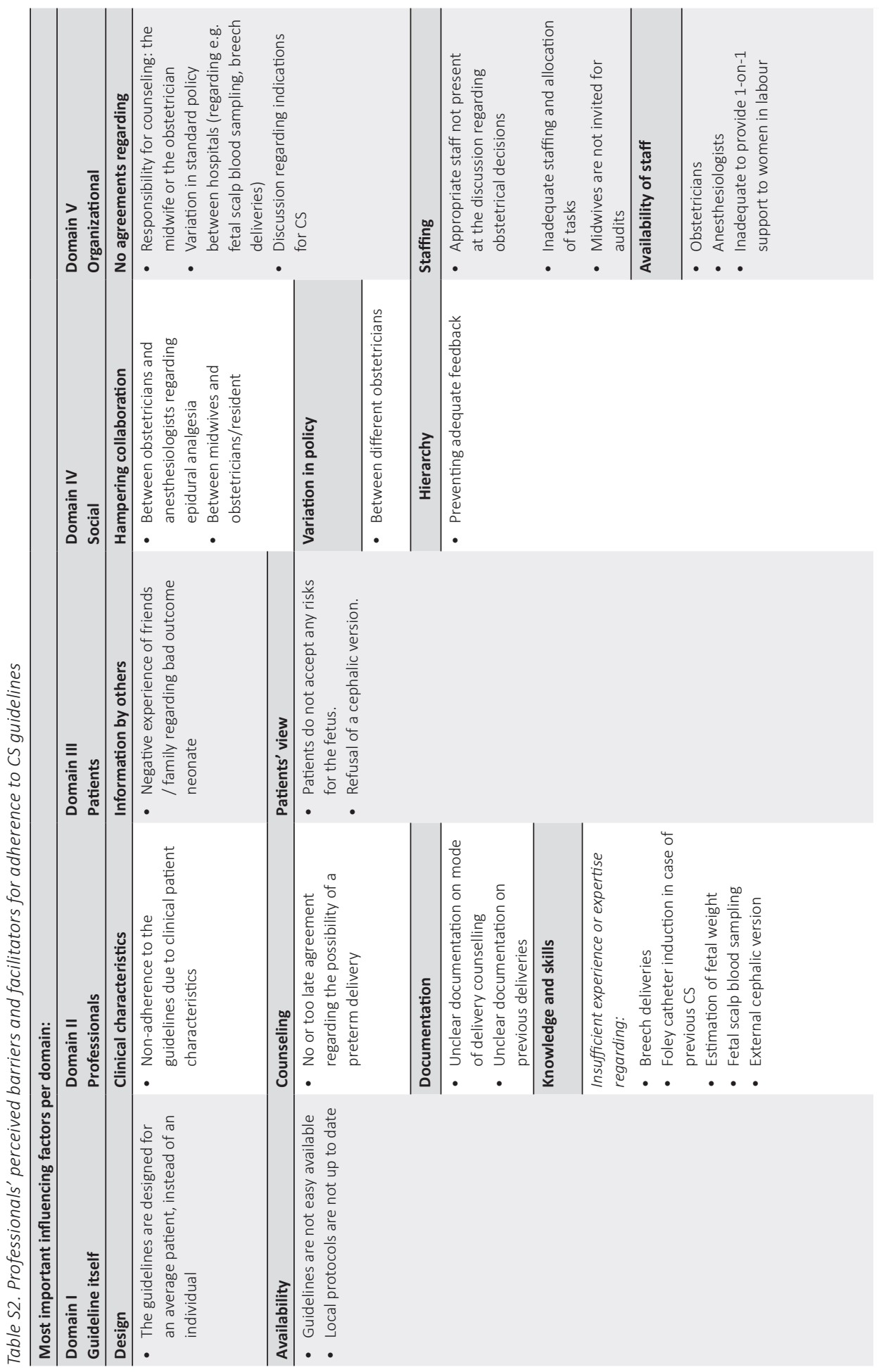




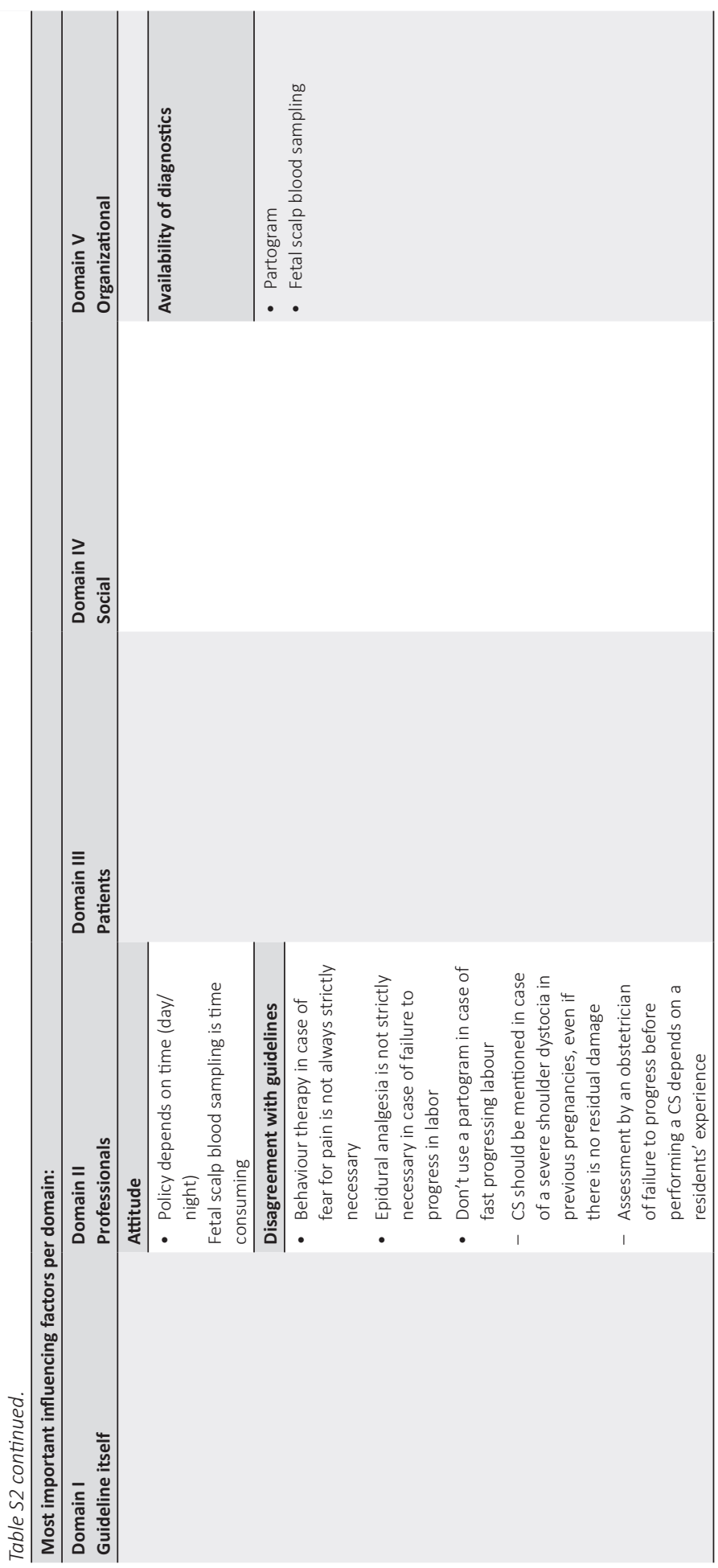




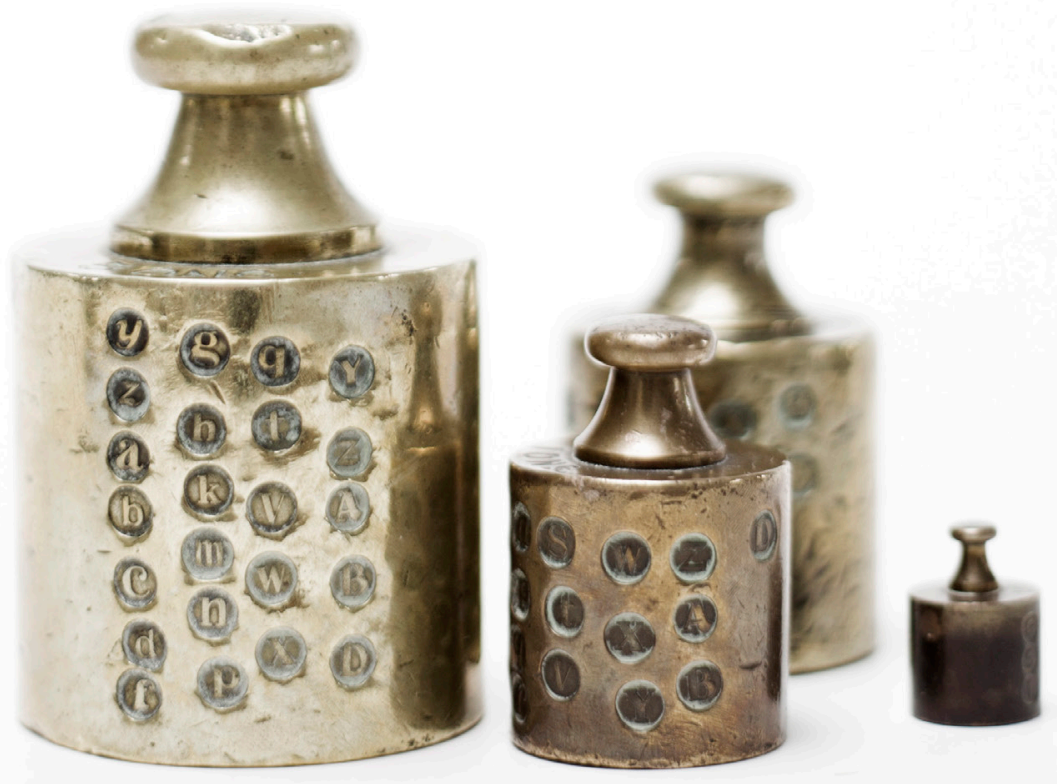


Changing the evaluation of caesarean section care: combining the Robson Ten-Group Classification System with valid quality indicators.

Sonja Melman, Rachel Schreurs, Carmen Dirksen, Sander van Kuijk, Jan Nijhuis, Luc Smits, Rosella Hermens, Hubertina Scheepers 


\section{Commentary}

The discussion on optimal CS rates is on-going. Although the World Health Organization (WHO) recommended an ideal caesarean section rate between $10 \%$ and $15 \%$, caesarean section rates of up to $19 \%$ are associated with lower maternal or neonatal mortality rates $[1,2]$. The Euro-Peristat study revealed wide variation in CS rates, ranging from $14.8 \%$ in Iceland to 52\% in Cyprus with no relation to neonatal outcome [3]. The Netherlands has a relatively low CS rate (17\%), but detailed analysis of guideline adherence showed room for improvement in many cases [4]. Even in a country with a "close to ideal rate", the rise in CS rates in 'low risk pregnancies' (healthy women with a singleton in cephalic position at term with an intended vaginal delivery) is remarkable [5]. The SIMPLE study showed that in these women emergency CS rates ranged from 2.5 to $12.3 \%$, which could largely be explained by patient characteristics.

In 2015, the WHO further recommended the use of the Robson Ten-Group Classification System (RTGCS) in order to categorise women in ten mutually exclusive obstetrical subgroups $[1,6]$. The international use of this system is advised in order to be able to compare CS rates between countries and hospitals and to allow an insight into changes in CS rates over time. Based on a systematic review, Torloni et al. concluded that the RTGCS was the most optimal classification system [7], yet this system makes no distinction between planned and unplanned CS. Moreover, it categorises women with induction of labour into the same group as women with planned CS [8].

The most important purpose of such a classification system would be the improvement of obstetrical care and preventing unwanted CS. However, simply comparing CS rates per hospital or country does not reflect appropriate use of a CS. In order to prevent unnecessary CS and improve care, it is essential to take the next step. We studied the Robson classification in the Netherlands, and the major contributors to the CS rate are not very different from other countries $[9,10]$ : nulliparous women with a singleton in cephalic position after 37 weeks in spontaneous labor (17.1\%) (group 1), nulliparous women with a singleton in cephalic position after 37 weeks induced or CS before labor (14.2\%) (group 2), and women with a previous CS (23.8\%) (group 5) (unpublished sub analysis of SIMPLE I data: available in the appendix). Therefore, even in a low CS rate setting as the Netherlands, the groups that mainly contribute to the CS rate remain identical. This supports the idea that improvement of care needs more than mere classification. In the SIMPLE study we developed 27 valid evidence based quality indicators, extracted from international guidelines, and measured these in actual care [4]. We identified groups that contribute mostly to the CS rates, in whom guidelines are frequently not adequately followed and, therefore, in which improvement of 
care is most likely to be effective.

In order to add more content to international comparison of CS rates, we suggest combining the major contributors to the CS rate based on the RTGCS with our quality indicators focused on content, particularly:

1) The percentage of women with a singleton in cephalic position after 37 weeks with one prior CS who are adequately counseled on the risks and benefits of intended vaginal birth after CS and are given a choice.

2) The percentage of nulliparous women with a singleton in cephalic position after 37 weeks who deliver by unplanned CS due to non-progressing labor in absence of signs of fetal distress, in whom the following actions are executed before a CS is performed:

a) Amniotomy, adequate pain relief and adequate oxytocin augmentation for at least 4 hours.

b) Active pushing at full dilation, and, if no contraindications exists, vaginal instrumental delivery is offered.

These indicators could serve both in a prospective registration and could also be used in an audit and feedback of CS cases [11]. 


\section{Appendix}

\section{Introduction}

The Robson Ten-Group Classification System was developed in 2001 in order to describe subgroups of women who experience different CS rates (Table 1) [6].

Table 1. Ten-group Classification System according to Robson

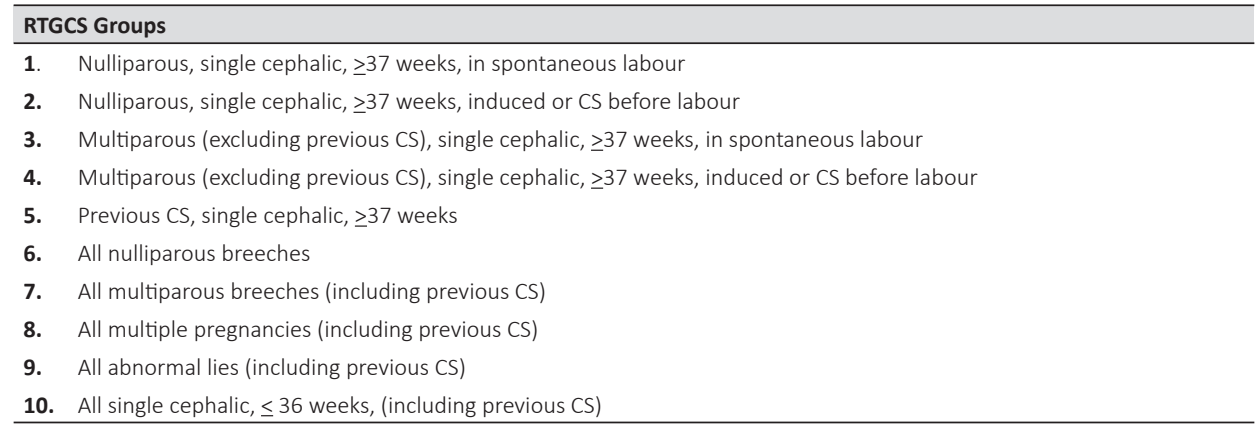

These ten groups are mutually exclusive, totally inclusive and prospectively identifiable. This classification system provides the opportunity to compare CS rates among subpopulations between institutions, as well as over time in the same institution [7]. Since 2001, several modifications have been proposed in order to optimize this system $[8,12,13]$. There are also new insights on the appropriate use of the RTGCS [14,15]. The RTGCS allows epidemiological comparison of CS care. However, this classification system does not provide insight into indications for a CS, or the actual care provided.

Another method of comparison and measurement of actual obstetric care in order to reduce CS rates is described in the SIMPLE study (caesarean Section IMPLEmentation) [4]. The RAND-modified Delphi method was applied to develop quality indicators on CS care. Next, these quality indicators were used to measure actual CS care, which allows the identification of groups of women where improvement of care might be possible.

Four possible target groups of women were identified; 1 ) suspected fetal distress during labour, 2) non-progressive labour, 3) continuous support during labour and 4) previous CS.

A ten group analysis was performed to examine the obstetric outcome in women who delivered in 21 different hospitals in The Netherlands (SIMPLE study population), in order to gain insight into the CS rate per risk group. 


\section{Results}

The results of the ten group analysis are given in table 2.

Table 2: Robson Ten-Group Classification RTGCS group

\begin{tabular}{|c|c|c|c|c|c|c|c|}
\hline & & $\begin{array}{c}\text { Total } \\
\text { deliveries } \\
\mathbf{N}(\%)\end{array}$ & $\begin{array}{c}\text { CS } \\
\text { deliveries } \\
\text { total } \mathbf{N}\end{array}$ & $\begin{array}{c}\text { CS rate } \\
\text { per group } \\
\%\end{array}$ & $\begin{array}{c}\text { Planned CS } \\
\text { per group } \\
\mathrm{N}(\%)\end{array}$ & $\begin{array}{l}\text { Emergency } \\
\text { CS per } \\
\text { group N (\%) }\end{array}$ & $\begin{array}{l}\text { Contribution } \\
\text { to CS rate \% }\end{array}$ \\
\hline 1. & $\begin{array}{l}\text { Nulliparous, single cephalic, } \geq 37 \\
\text { weeks, in spontaneous labour }\end{array}$ & 1395 (31.1) & 171 & 12.3 & - & $171(12.3)$ & 17.2 \\
\hline 2. & $\begin{array}{l}\text { Nulliparous, single cephalic, } \geq 37 \\
\text { weeks, induced or CS before } \\
\text { labour }\end{array}$ & $593(13.2)$ & 140 & 23.6 & $26(4.4)$ & $114(19.2)$ & 14.1 \\
\hline 3. & $\begin{array}{l}\text { Multiparous (excluding previous } \\
\mathrm{CS} \text { ), single cephalic, } \geq 37 \text { weeks, } \\
\text { in spontaneous labour }\end{array}$ & $812(18.1)$ & 27 & 3.3 & - & $27(3.3)$ & 2.7 \\
\hline 4. & $\begin{array}{l}\text { Multiparous (excluding previous } \\
\mathrm{CS} \text { ), single cephalic, } \geq 37 \text { weeks, } \\
\text { induced or CS before labour }\end{array}$ & $506(11.3)$ & 63 & 12.4 & $40(7.9)$ & $23(4.5)$ & 6.3 \\
\hline 5. & $\begin{array}{l}\text { Previous CS, single cephalic, } \geq 37 \\
\text { weeks }\end{array}$ & $478(10.7)$ & 237 & 49.6 & $155(32.4)$ & $82(17.2)$ & 23.8 \\
\hline 6. & All nulliparous breeches & $163(3.6)$ & 128 & 78.5 & $113(69.3)$ & $15(9.2)$ & 12.9 \\
\hline 7. & $\begin{array}{l}\text { All multiparous breeches } \\
\text { (including previous CS) }\end{array}$ & $92(2.1)$ & 69 & 75 & $61(66.3)$ & $8(8.7)$ & 6.9 \\
\hline 8. & $\begin{array}{l}\text { All multiple pregnancies } \\
\text { (including previous CS) }\end{array}$ & $85(1.9)$ & 33 & 38.8 & $20(23.5)$ & $13(15.3)$ & 3.3 \\
\hline 9. & $\begin{array}{l}\text { All abnormal lies (including } \\
\text { previous CS) }\end{array}$ & $29(0.6)$ & 29 & 100 & $25(86.2)$ & $4(13.8)$ & 2.9 \\
\hline 10 & $\begin{array}{l}\text { All single cephalic, } \leq 36 \text { weeks, } \\
\text { (including previous CS) }\end{array}$ & $328(7.3)$ & 97 & 29.6 & $71(21.7)$ & $26(7.9)$ & 9.8 \\
\hline \multicolumn{2}{|c|}{ Total } & $4481(100)$ & 994 & - & 511 & 483 & 100 \\
\hline
\end{tabular}

The CS rate in this population is $22 \%$, with $11 \%$ planned CS and $11 \%$ emergency CS. Women in groups 1 to 4 represent relatively uncomplicated pregnancies. There are 3306 women classified (73.8\%) in these four groups, with a contribution to the total CS rate of $40.3 \%$. Group 1 (nulliparous women, single cephalic, full-term pregnancies in spontaneous labour), is the largest group in our selected population, representing $31 \%$ of the women $(N=1395)$. In this group of uncomplicated pregnancies 171 women delivered by CS (12.3\%), with a relative contribution to the total CS rate of $17.2 \%$.

Of the 593 women in group 2 (nulliparous, single cephalic, full term, induced or CS before labour) $23.6 \%$ delivered by CS. Induction of labour contributed more to the CS rate in this group then planned CS: $19.2 \%$ emergency CS rate versus $4.4 \%$ planned CS rate, respectively. The contribution of group 2 to the total CS rate is $14.1 \%$. 
The CS rate in group 3 (multiparous, no previous CS, single cephalic, $\geq 37$ weeks, in spontaneous labour), however, is the lowest of the groups described to be uncomplicated pregnancies, with a CS rate of $3.3 \%$ and a contribution to the total CS rate of $2.7 \%$.

In group 4 (multiparous, no previous CS, single cephalic, $\geq 37$ weeks, induced or CS before labour) $12.4 \%$ of the 506 women delivered by CS, with a relative contribution to the total CS rate of $6.3 \%$.

The largest contributor to the total CS rate in our population is group 5 (multiparous women, single cephalic, full-term pregnancies with a previous uterine scar). Fifty percent of the 478 women in this group delivered by CS, representing a contribution of $23.8 \%$ to the total CS rate. 


\section{References}

1. World Health Organization. Appropriate technology for birth. Lancet 1985;2:436-7

2. Molina G, Weiser TG, Lipsitz SR, Esquivel MM, Uribe-Leitz T, Azad T et al. Relationship Between Cesarean Delivery Rate and Maternal and Neonatal Mortality. JAMA 2015;314:2263-2270.

3. Macfarlane AJ, Blondel B, Mohangoo AD, Cuttini M, Nijhuis J, Novak Z et al. Wide differences in mode of delivery within Europe: risk-stratified analyses of aggregated routine data from the Euro-Peristat study. BJOG 2016;123:559-568.

4. Melman S, Schoorel EC, de Boer K, Burggraaf H, Derks JB, van Dijk D et al. Development and Measurement of Guidelines-Based Quality Indicators of Caesarean Section Care in the Netherlands: A RAND-Modified Delphi Procedure and Retrospective Medical Chart Review. PLoS One 2016 19;11:e0145771.

5. Kwee A, Elferink-Stinkens PM, Reuwer PJHM, Bruinse HW. Trends in obstetric interventions in the Dutch obstetrical care system in the period 1993-2002. Eur J Obstet Gynecol Reprod Biol 2007;132:70-75.

6. Robson MS: Can we reduce the caesarean section rate? Best Pract Res Clin Obstet Gynaecol 2001, 15:179-194.

7. Torloni MR, Betran AP, Souza JP, Widmer M, Allen T, Gulmezoglu M, et al. Classifications for cesarean section: a systematic review. PloS one 2011;6:e14566.

8. Farine D, Shepherd D. Classification of caesarean sections in Canada: the modified robson criteria. J Obstet Gynaecolog Can 2012;34:976-9.

9. Triunfo S, Ferrazzani S, Lanzone A, Scambia G et al. Identification of obstetric targerts for reducing caesarean section rate using the Robson Ten Group Classification in a tertiary level hospital. Eur J Obstet Gynecol Reprod Biol 2015;189:91-95.

10. Vogel JP, Betrán AP, Vindevoghel N, Souza JP, Torloni MR, Zhang J et al. Use of the Robson classification to assess caesarean section trends in 21 countries: a secondary analysis of the WHO multicountry surveys. Lancet 2015;3: e260-e270

11. Van Dillen J, Mesman JAJM, Zwart JJ, Bloemenkamp KWM, Van Roosmalen J: Introducing maternal morbidity audit in the Netherlands. BJOG 2010,117:416-421

12. Bertrán AP, Vindevoghel N, Souza JP, Gülmezoglu AM, Torloni MR. A systematic review of the Robson classification for ceasarean section: what works, doesn't work and how to improve it. PLoS One 2014;9:e97769.

13. Robson MS. The 10-Group Classification System - a new way of thinking. Am J Obstet Gynecol 2018;219: 1-4.

14. Robson M. The Ten Group Classification System (TGCS) - a common starting point for more detailed analysis. BJOG $2015 ; 122: 701$.

15. Boatin AA, Cullinane F, Torloni MR, Betrán AP. Audit and feedback using the Robson classification to reduce casesarean section rates: a systematic review. BJOG 2018;125:36-42. 

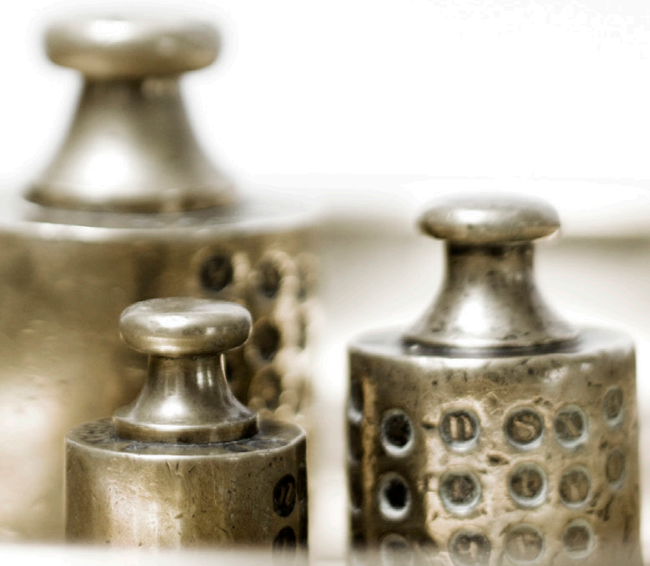


\section{Predicting successful intended vaginal delivery after previous \\ caesarean section: \\ external validation of two \\ predictive models in a Dutch \\ nationwide registration-based \\ cohort with a high intended \\ vaginal delivery ratio.}

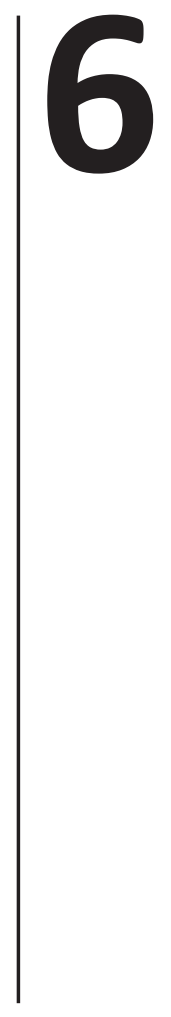

ENC Schoorel, S Melman, SMJ van Kuijk, WA Grobman, A Kwee, BWJ Mol, JG Nijhuis, LJM Smits, R Aardenburg, K de Boer, FMC Delemarre, IM van Dooren, MTM Franssen, G Kleiverda, M Kaplan, SMI Kuppens, FTH Lim, JM Sikkema, E Smid-Koopman, H Visser, FPJM Vrouenraets, M Woiski, RPMG Hermens, HCJ Scheepers 


\section{Abstract}

\section{Objective}

To externally validate two models from the United States (entry-to-care (ETC) and close-todelivery (CTD)) that predict successful intended vaginal birth after caesarean (VBAC) for the Dutch population.

\section{Design and setting}

A nationwide registration-based cohort study. Seventeen hospitals in the Netherlands.

\section{Population}

Seven hundred and sixty-three pregnant women, each with one previous caesarean section (CS) and a viable singleton cephalic pregnancy without a contraindication for an intended VBAC.

\section{Methods}

The ETC model comprises the variables maternal age, pre-pregnancy body mass index (BMI), ethnicity, prior vaginal delivery, prior VBAC and prior nonprogressive labour. The CTD model replaces pre-pregnancy $\mathrm{BMI}$ with third-trimester $\mathrm{BMI}$ and adds estimated gestational age at delivery, hypertensive disease of pregnancy, cervical examination and induction of labour. We included consecutive medical records of eligible women who delivered in 2010. For validation, individual probabilities of women who had an intended VBAC were calculated.

\section{Main outcome measures}

Discriminative performance was assessed with the area under the curve (AUC) of the receiver operating characteristic and predictive performance was assessed with calibration plots and the Hosmer-Lemeshow (H-L) statistic.

\section{Results}

Five hundred and fifteen (67\%) of the 763 women had an intended VBAC; $72 \%$ of these (371) had an actual VBAC. The AUCs of the ETC and CTD models were 68\% (95\% Cl 63-72\%) and 72\% (95\% Cl 67-76\%), respectively. The $\mathrm{H}$-L statistic showed a $P$-value of 0.167 for the ETC model and $P=0.356$ for the CTD model, indicating no lack of fit.

\section{Conclusion}

External validation of two predictive models developed in the United States revealed an adequate performance within the Dutch population. 


\section{Introduction}

After a first caesarean section (CS), a pregnant woman can opt for an elective repeat CS (ERCS) or an intended vaginal birth after caesarean (VBAC) (i.e. a trial of labour), which will result in an actual (successful) VBAC or an emergency CS (unsuccessful VBAC). Discussing the risks of both options is a substantial part of counselling on mode of delivery, and obviously the probability of having an actual VBAC is a key component [1,2]. Published success rates for VBAC worldwide vary between 60 and 80\% [3]. However, these rates are not necessarily applicable for counselling, since individual probabilities may vary due to factors relating to demography, obstetric history and current pregnancy of the woman $[3,4]$. Hence, a personalised prediction of VBAC may lead to a more refined counselling. Furthermore, with regard to clinical outcomes, personalised prediction could contribute to risk estimation because actual incidences of major maternal morbidity are lowest in women who have a VBAC $(0.2 \%)$, followed by women having an ERCS $(0.8 \%)$, and are highest in women having unsuccessful VBAC (3.8\%) [5]. In addition, several studies have shown that low probabilities of successful VBAC are related to relatively high risks of major feto-maternal morbidity $[6,7]$. Several scoring models that aim for a personalised prediction of successful intended VBAC have been published $[3,8]$. In this work, the predictive models of Grobman et al. are evaluated $[9,10]$. These models can be used early in pregnancy [9] and at the onset of labour [10] in order to estimate the probability of successful intended VBAC during an at term delivery. Both models have previously been successfully validated in an independent cohort in the United States and were called the 'entry-to-care model' (ETC) and the 'close-todelivery model' (CTD) [11,12]. Additionally, the ETC model has been successfully validated for a Japanese population [13]. However, differences in, for example, population characteristics and setting may affect the validity of the predictive models in European countries like the Netherlands. For instance, in the United States, the VBAC rate when the predictive models were derived was 12-22\% [14]; this declined to approximately $8.3 \%$ in 2007 [15]. In most European countries reported VBAC rates are higher, for example 54\% in the Netherlands [16] and $30-37 \%$ in the United Kingdom $[2,17]$. Hence, in this study we aim to externally validate the prediction models of Grobman et al. for the Dutch population $[9,10]$.

\section{Methods}

\section{Setting}

This nationwide registration-based cohort study was performed in 17 hospitals in the Netherlands, with a good representation of all geographic regions and hospital types. Hospitals types included university teaching hospitals $(n=5)$, nonuniversity teaching hospitals 
$(n=7)$ and nonuniversity nonteaching hospitals $(n=5)$. Approval for this study was obtained at the Medical Ethical Committee (CMO) of Maastricht University Medical Centre+ (MUMC+) (MEC number 09-4-047-13).

\section{Population}

The two predictive models were designed for women who have a vertex singleton pregnancy and a history of one low-transverse CS and who delivered at term (gestational age $\geq 37$ weeks), therefore only women who met these criteria were included in the present study. As in the studies of Grobman et al. $[9,10]$, women with an unknown indication for previous CS, an antepartum intrauterine fetal demise or a contraindication for vaginal delivery were excluded. Contraindications for vaginal delivery were defined as placenta praevia and a uterine scar with extension into the fundus.

Since we expected a large difference between the VBAC rate in the United States and the current VBAC rate in the Netherlands, we collected data from women who had an intended VBAC and from women who had an ERCS. The main consideration was to estimate the current VBAC rate in the Netherlands and subsequently to fully evaluate the applicability of the models in the Dutch population by comparing the baseline characteristics of the intended VBAC group and the ERCS group.

\section{Sample size}

The sample size was calculated according to the 'rule of thumb' of at least ten events per variable in the predictive model [18]. An event was defined as an unsuccessful intended VBAC. Based on previously published data, it was assumed that the percentage of unsuccessful intended VBACs in the Netherlands would be $24 \%$ [16]. As the predictive models contained as many as 12 variables per model, the calculated minimum sample size was 500 subjects $(12 \times 10 / 0.24)$.

\section{Data collection}

At all participating sites, data were extracted from consecutive birth records according to a standardized operating procedure by using customized case report forms. Information was obtained on all predictive indicators included in the predictive models. Data were obtained by trained research nurses, medical doctors or senior medical students. In order to achieve the required sample size, each participating hospital was asked to include 30 consecutive cases of intended VBAC and all ERCSs in the same time interval, starting from 1 January 2010.

\section{Variables}

Variables were defined as described in the original articles of Grobman et al. $[9,10]$.The 
outcome variable used for validating the predictive models was the outcome of the intended VBAC, i.e. either successful intended VBAC (vaginal birth) or unsuccessful intended VBAC (emergency CS).

To be able to incorporate all variables despite the different units and definitions used in the two countries, some of the collected data had to be converted or redefined. All decisions on the conversion and redefinition of variables were approved by both a Dutch and an American obstetrician (HS and WG). The variables that had to be adapted were 'ethnicity' (in the United States the categories were African-American/Hispanic/White and others), 'fetal station' and 'cervical effacement'. In the Netherlands seven categories of ethnicity are used (Dutch, other European, Mediterranean, African, Indo-surinamese, Asian and 'other'). To correspond to the categories in the original prediction models, the variable 'AfricanAmerican' was set equal to the Dutch variable 'African'. The variable 'Hispanic', did not match any of the Dutch categories and was therefore abolished. Subsequently, the variable 'White and others' comprised all Dutch ethnicity categories except for 'African'. The variable 'fetal station' was collected according to the 'Hodge classification system', which ranges from Hodge $\mathrm{O}(\mathrm{HO})$ to Hodge $4(\mathrm{H} 4)$. Fetal station was converted into the American classification system, which ranges from ballottable (B) to +5 . It was redefined as follows: $\mathrm{HO}=-5 ; \mathrm{H} 1=-3$; $\mathrm{H} 2=-1 ; \mathrm{H3}=0 ; \mathrm{H} 4=+3$. The variable 'cervical effacement' was collected in three categories, namely (1) $\leq 25 \%$, (2) $25-50 \%$ and (3) $\geq 50 \%$, as these are the categories in which these data are registered in the Netherlands. For analysis we set category 1 equal to 20\%, category 2 equal to $40 \%$ and category 3 equal to $75 \%$. Furthermore, the variable 'third trimester body mass index (BMI)' was approximated by adding $15 \mathrm{~kg}$ to 'pre-pregnancy weight'; this was considered appropriate for the Dutch population based on expert opinion.

\section{Data quality and missing data}

Data were entered and checked for inconsistencies. Inconsistent and incomplete data were double-checked directly with the hospital concerned. As shown in Table 5.1, for most variables there was only a small quantity of missing data. However, pre-pregnancy BMI was missing in $24 \%$ of women. A multiple imputation strategy was used for data analysis, since complete case analysis alone can result in a large loss of power and might yield biased parameter estimates.

\section{Data analysis}

\section{Study cohort characteristics}

Characteristics of the women who had an ERCS and women who had an intended VBAC were compared. To compare proportions, the chi-squared test, or when appropriate Fisher's exact test, was used. For continuous variables, an independent sample $t$ test was used for all 
samples as data were normally distributed. A $P$-value $<0.05$ was used to indicate statistical significance.

\section{Predicted probabilities}

To validate the prediction models, for each patient who had an intended VBAC an individual probability of achieving VBAC was calculated with the following prediction equations obtained from the research articles of Grobman et al. [9,10]:

1. The ETC model [9]:

$\exp (w) /[1+\exp (w)]$

where

$w=3.766-0.039$ (age, years)-0.060 (pre-pregnancy BMI)-0.671 (African-American ethnicity) -0.680 (Hispanic ethnicity) +0.888 (previous vaginal delivery) +1.003 (vaginal delivery after previous CS) -0.632 (previous CS due to nonprogressive labour).

2. The CTD model [10]:

$\exp (w) /[1+\exp (w)]$

where

$w=7.059-0.037$ (age, years)-0.044 (third-trimester BMI)-0.460 (African-American ethnicity)-0.761 (Hispanic ethnicity)+0.955 (previous vaginal delivery)+0.851 (vaginal delivery after previous CS) -0.655 (previous CS due to nonprogressive labour)-0.109 (estimated gestational age at delivery)-0.499 (hypertensive disease of pregnancy) +0.044 (cervical effacement, deciles) +0.109 (cervical dilation, 0-6 cm)+0.082 (fetal station, $B$ to +5 , entered as 0 to 11$)-0.452$ (labour induction).

Additionally, using the ETC model we calculated the mean predicted probability of achieving VBAC for women in the ERCS group and compared it with the mean predicted probability in the intended VBAC group. The purpose of this comparison was to evaluate whether the variables of the predictive models are already being taken into account during counselling. As data were not normally distributed, the mean predicted probabilities of achieving VBAC were compared using a Mann-Whitney $U$ test. We only performed this analysis with the ETC model because the CTD model includes intrapartum factors and was therefore not applicable to the ERCS group.

\section{Discriminative and predictive performance}

The discriminative performance of the predictive models was assessed using a receiver operating characteristic (ROC). The ROC was obtained by plotting sensitivity against 1-specificity. Sensitivity was defined as the fraction of VBACs that were correctly predicted for a particular 
cut-off point, whereas specificity was defined as the fraction of unsuccessful intended VBACs that were correctly predicted. The ability of the models to discriminate between women with a high and low probability of achieving a VBAC was assessed using the area under the curve (AUC) of the ROC. The AUC can vary between 0.5 and 1.0, in which a value of 0.5 represents no discriminative capacity and 1.0 represents excellent discriminative capacity.

The predictive performance of the models was assessed by a calibration curve. The calibration curve was computed to show the relation between predicted probability of achieving VBAC and the observed VBAC rate. To obtain these values, the predicted probability was categorized into quantiles. In each quantile, the mean predicted VBAC rate was calculated and plotted against the observed VBAC rate in the corresponding quantile. In addition, to assessing goodness-of-fit, we computed the Hosmer-Lemeshow $(\mathbf{H}-\mathbf{L})$ statistic. The $\mathrm{H}-\mathrm{L}$ statistic measures the fit of the calibration curve with the assumption (null hypothesis) that observed and predicted values are equal. A $P$-value $<0.05$ was considered to show lack of fit of the tested prediction models.

\section{Distribution of probabilities}

In order to determine the clinical utility of the models, we evaluated whether the model could classify a notable portion of women away from the VBAC population mean. Hence, we evaluated the distribution of probabilities amongst the cohort. The distributions were plotted in bar charts on the $x$-axis in the calibration plot. Additionally, we computed the percentage of the cohort that can be classified away from the VBAC population mean; we used cut-off values of $60 \%$ or less and $80 \%$ or higher.

\section{Software}

Statistical analyses and plots were performed using SPSS (SPSS v. 18.0) software and R, a language and environment for statistical computing.

\section{Results}

\section{Inclusions}

We reviewed 9833 consecutive medical records of women who had delivered in the participating hospitals since January 2010. One thousand and sixty-eight women (11\%) had a history of CS, 763 of whom (71\%) met the inclusion criteria. Of these 763 women eligible for intended VBAC, 515 (67\%) had an intended VBAC and 248 (33\%) had an ERCS. Three hundred and seventy-one women (72\%) delivered vaginally, resulting in an actual VBAC rate in our study cohort of 49\% (371/763). 


\section{Study cohort characteristics}

The population distributions with respect to the variables contained in the two predictive models are shown in Table 5.1. Women who had a previous vaginal delivery and/or a previous VBAC were more likely to attempt a VBAC. Women who had an intended VBAC also had a significantly lower BMI, although the actual difference between groups was small. On the other hand, women with a previous CS due to nonprogressive labour more often opted for ERCS. Women who had an ERCS delivered at a significantly lower gestational age. Based on the ETC model, women who chose a VBAC had a significantly higher mean predicted probability $(P<0.00)$ of successful intended VBAC $(72 \pm 14 \%)$ than women who chose an ERCS $(64 \pm 14 \%)$

Table 5.1 Baseline characteristics of study cohort of women with a previous caesarean section.

\begin{tabular}{|c|c|c|c|c|}
\hline Variable & $\begin{array}{l}\text { Missing data intended } \\
\text { VBAC /ERCD }(n / n)\end{array}$ & $\begin{array}{l}\text { Intended VBAC } \\
(n=515)\end{array}$ & $\begin{array}{l}\text { ERCS } \\
(n=248)\end{array}$ & P-value ${ }^{a}$ \\
\hline Maternal age (years, mean \pm SD) & $2 / 4$ & $32 \pm 5$ & $33 \pm 4$ & 0.15 \\
\hline \multicolumn{5}{|l|}{ Ethnicity (n, (\%)) } \\
\hline Dutch & $15 / 12$ & $388(75)$ & $192(77)$ & 0.53 \\
\hline Mediterranean & & $37(7)$ & $11(5)$ & 0.14 \\
\hline Other European & & $17(3)$ & $11(4)$ & 0.44 \\
\hline African & & $24(5)$ & $6(3)$ & 0.14 \\
\hline Indo-Surinamese & & $7(1)$ & $1(0)$ & 0.45 \\
\hline Asian & & $12(2)$ & $7(3)$ & 0.68 \\
\hline Other & & $15(3)$ & $8(3)$ & 0.81 \\
\hline Pre-pregnancy BMI $\left(\mathrm{kg} / \mathrm{m}^{2}\right.$, mean $\left.\pm \mathrm{SD}\right)$ & $124 / 79$ & $25 \pm 6$ & $27 \pm 7$ & $<0.00$ \\
\hline Previous CS due to failure to progress (n, (\%)) & $0 / 0$ & 201(39) & $135(54)$ & $<0.00$ \\
\hline Any previous vaginal delivery $(n,(\%))$ & $0 / 0$ & $127(25)$ & $25(10)$ & $<0.00$ \\
\hline Previous VBAC (n, (\%)) & $0 / 0$ & 99(19) & $8(3)$ & $<0.00$ \\
\hline PE/HELLP (n, (\%)) & $0 / 2$ & $9(2)$ & $6(2)$ & 0.58 \\
\hline Gestational age at delivery (days, mean \pm SD) & $0 / 0$ & $279 \pm 8$ & $273 \pm 9$ & $<0.00$ \\
\hline Cervical dilation ( $\mathrm{cm}$, mean $\pm \mathrm{SD}$ ) & $11 /^{b}$ & $3 \pm 2$ & b & b \\
\hline Cervical effacement $(\%,($ mean \pm SD $))$ & $56 /{ }^{b}$ & $64 \pm 19$ & b & b \\
\hline Fetal station $(B,-5-+5$, mean $\pm S D)$ & $57 /{ }^{b}$ & $-2 \pm 2$ & b & b \\
\hline Induction of labour (n, (\%)) & $0 /{ }^{b}$ & $132(26)$ & b & b \\
\hline
\end{tabular}

a Results of $\chi^{2}$-tests/ Fisher's exact test / t-tests; ${ }^{b}$ Not applicable. SD: standard deviation, VBAC: vaginal birth after caesarean, ERCS: elective repeat caesarean section, CS: caesarean section, BMI: body mass index, PE: Preeclampsia HELLP syndrome: haemolysis, elevated liver-enzymes, low platelets, B: ballottement.

\section{Discriminative performance}

The discriminative performance of the predictive models is shown in Figure 5.1. The ROC of the ETC model has an AUC of $68 \%(95 \% \mathrm{Cl} 63-72 \%)$. The ROC of the CTD model has an AUC of $72 \%$ (95\% Cl 67-76\%). 


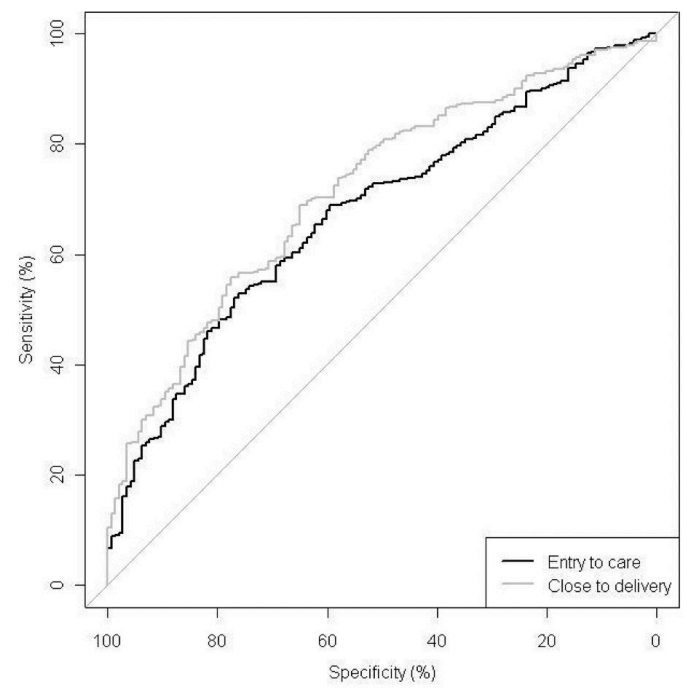

Figure 5.1 ROC of the entry-to-care model (AUC 68\%; 95\% Cl 63-72\%) and the close-to delivery model (AUC 72\%; 95\% Cl 67-76\%), indicating the discriminative performance of both models concerning the probability of a successful vaginal birth after CS.

\section{Predictive performance}

The overall calibration of both predictive models was good. The mean successful intended VBAC rate in this study cohort was $72 \%$. The mean predicted probabilities for successful intended VBAC in the ETC and the CTD models were $72 \pm 14 \%$ and $70 \pm 16 \%$, respectively. The predictive performances of the models are shown in the calibration curves in Figures 5.2 and 5.3.

Both models show acceptable calibration; the calibration in the high-probability ranges was particularly good. The CTD shows better calibration than the ETC model. The H-L statistic showed a $P$-value of 0.17 for the ETC model and 0.36 for the CTD model, which indicates reasonable calibration of both predictive models.

\section{Distribution of probabilities}

The bar charts on the $x$-axes of Figures 5.2 and 5.3 show the distribution of probabilities of successful VBAC amongst the cohort. Figure 5.2 shows that when the ETC model is applied, the majority of the cohort has a predicted probability around or above the VBAC population mean of $60-80 \%$. In our cohort, $27 \%$ had a predicted probability above the VBAC population mean as these women had a predicted probability of $80 \%$ or higher. Furthermore, $19 \%$ of the women had a predicted probability below 60\%. As shown in Figure 5.3, with application of the CTD model the distribution of predicted probabilities is also concentrated around and 
above the VBAC population mean. In total, $31 \%$ of women had a predicted probability above $80 \%$, and $26 \%$ had a predicted probability below $60 \%$.

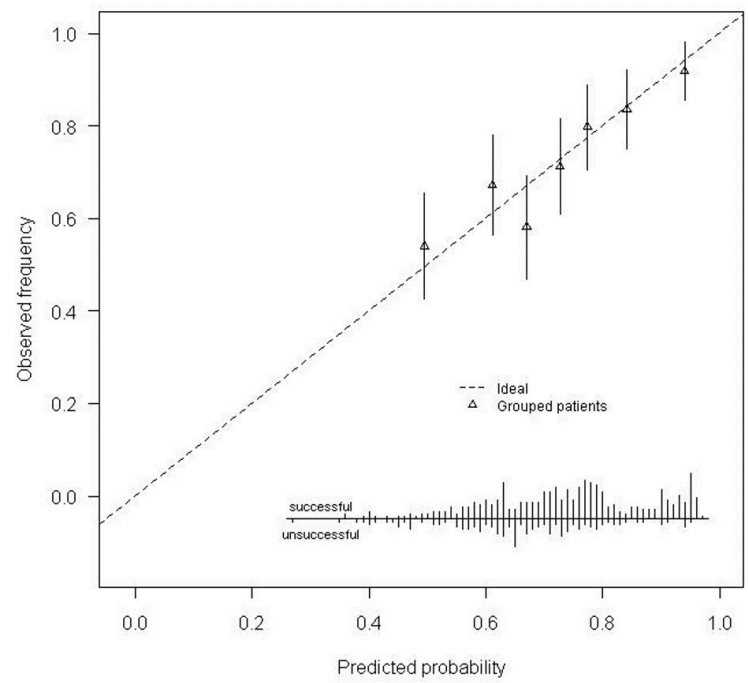

Figure 5.2 Calibration plot of the entry-to-care model with the observed frequency of a successful vaginal birth after caesarean section by the predicted probability. The triangles indicate quantiles of women with a similar predicted probability of success.

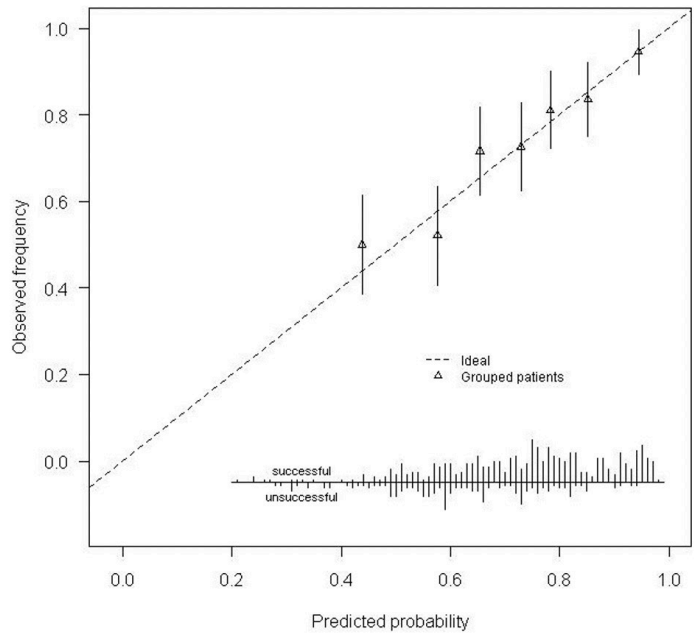

Figure 5.3 Calibration plot of the close-to-delivery model with the observed frequency of a successful vaginal birth after caesarean section by the predicted probability. The triangles indicate quantiles of women with a similar predicted probability of success. 


\section{Comment}

\section{Main findings}

External validation of two predictive models developed in the United States revealed adequate performance of both models within the Dutch population. Although overall calibration was acceptable, it was particularly good in the range of high predicted probability of successful intended VBAC. Discriminative capacity was reasonable for both models. Most women had a score within the population mean of 60-80\% [3], yet a notable minority was classified away from this population mean. Further, this study shows that in the Netherlands intended VBAC is still common practice, as shown by the intended VBAC rate of $67 \%$. Our results also suggest that preselection already occurs to some extent without applying a model.

\section{Interpretation}

According to guidelines on prognostic research, even a predictive model that seems promising requires external validation in different populations and settings [19]. Ethnicity and the probability of attempting VBAC were the main observed differences between the Dutch and American settings, although other factors like intrapartum policy may also exist. We consider our results to be roughly generalizable to most other western European countries with comparable ethnicities and VBAC rates. External validation in our Dutch cohort showed some loss of discriminative performance, as the original AUCs were $75 \%$ (95\% Cl 74-77\%) instead of $68 \%$ (95\% Cl 63-72\%) for the ETC model and $77 \%$ (95\% Cl 76-78\%) instead of and $72 \%$ (95\% Cl 67-76\%) for the CTD model. As shown, this finding was more pronounced for the ETC model. These findings are consistent with the previous validation studies performed in an American cohort by Costantine et al. who used a validation method comparable to our study $[11,12]$. However, the results contrast with the findings in a Japanese cohort where an AUC of 80\% (95\% Cl 72-89\%) was obtained [13]. However, because no information was provided in that article on variable conversion and there appeared to be an additional selection criterion regarding whether women were actually in labour, no actual comparison with our results could be made.

A review by Kaimal et al. highlighted that most women would like to be involved in decisionmaking about mode of birth [20]. Also, women expressed their wish for personalised information [20]. Hence, implementation of a predictive model could provide this tailored information by allowing estimation of the risk of emergency CS and the related risk of fetomaternal morbidity $[6,7]$.

The ideal predictive model would distinguish between a successful intended VBAC and a failed intended VBAC by polarising the cohort into two groups: women with a very high 
predicted probability and women with a very low predicted probability of achieving a VBAC. In comparison with other models that predict successful VBAC, the performance of the ETC and CTD models is average to good [4,8]. However, for decision-making about mode of delivery after previous CS we consider it helpful to also distinguish women with a high or low probability of VBAC from those with an average probability. The ETC and CTD models show the potential to classify a notable portion of women away from the population mean, which might induce better a distribution with regard to risk classification of women amongst intended VBAC and ERCS. Therefore we think that a predictive model could not only contribute to more personalised counselling but also to a reduction in feto-maternal morbidity. However, the actual usefulness of such a model in terms of usability, applicability, change in birth preferences and feto-maternal morbidity should be further explored in a randomised controlled trial.

\section{Strengths and weaknesses}

A strength of this study is that it was performed in a multicentre setting with a good representation of types of hospitals and geographic regions in the Netherlands, which increased the external validity of our results. Furthermore, our data collection provides insight into the current (intended) VBAC rates in the Netherlands and into the prognostic profiles of women who opt for an intended VBAC and ERCS. By performing classification analysis we are able to show the subgroup of women who will have a probability of VBAC that is different from current population means [1,2].

We also recognise some limitations to our study. Firstly, there was a possible loss of discriminative performance of the validated models due to the necessary redefinition and conversion of variables into Dutch units. We had to redefine fetal station from a scale consisting of 12 steps ranging from $B$ to -5 to +5 to the Dutch scale that consists of five steps and ranges from 0 to 4 . Redefinition could induce misclassification and loss of refinement within variables, and thereby compromise model performance. Furthermore, in both models ethnicity is an important predictor. Though ethnicity has been recognized as an important demographic factor with regard to the probability of successful $V B A C,{ }^{4}$ the underlying mechanism is unknown and might be influenced by socioeconomic factors. Therefore, the ethnicity categories might not be compatible in other settings. Hence, we recommend reestimation of ethnicity and the intrapartum variables before application of the models in an impact study or clinical practice. A second drawback is that we had to approximate the variable 'third trimester BMI' as it could not be obtained from the charts. This may have led to imprecision and impairment of the performance of the models. Thirdly, the models would ideally be evaluated through application in a prospective setting. Application of the models might induce different birth preferences in women, selecting women with more favourable 
prognostic profiles for successful VBAC. This might alter model performance. Furthermore, a limitation with regard to the validated models that must be addressed concerns the timing of counselling. We consider that, from a medical point of view, counselling on mode of delivery should ideally occur in the third trimester of pregnancy, because then other factors can be incorporated that are known in late pregnancy such as estimated fetal weight (EFW) and whether labour needs to be induced. The ETC model does not take these factors into account whilst the CTD model is applicable when there is an indication for induction of labour or when labour has already started. In this regard, in terms of practical use, a predictive model that can be used in the third trimester would be more suitable for the Dutch setting.

\section{Conclusion}

External validation of two predictive models developed in the United States revealed adequate performance of both models within the Dutch setting. The predictive models can classify a notable portion of women away from the VBAC population mean. However, whether women indeed perceive the information on probability of successful VBAC as useful and whether the models hold when applied in a prospective setting should be additionally evaluated. Additional redefinition of the 'ethnicity' variable for a western European setting and transformation of both models into one model for third-trimester counselling could enhance model performance and increase applicability to the Dutch setting. 


\section{References}

1. ACOG Practice bulletin no. 115: Vaginal birth after previous cesarean delivery. Obstet Gynecol 2010;116:450-463.

2. RCOG Green-top Guideline no. 45: Birth after previous caesarean birth. RCOG Press; 2007.

3. Grobman WA. Rates and prediction of successful vaginal birth after cesarean. Semin Perinatol 2010;34:244-8.

4. Guise JM, Denman MA, Emeis C, et al. Vaginal birth after cesarean: new insights on maternal and neonatal outcomes. Obstet Gynecol 2010;115:1267-1278.

5. McMahon MJ, Luther ER, Bowes WA, Jr., Olshan AF. Comparison of a trial of labor with an elective second cesarean section. N Engl J Med 1996;335:689-695

6. Grobman WA, Lai Y, Landon MB, et al. Can a prediction model for vaginal birth after cesarean also predict the probability of morbidity related to a trial of labor? Am J Obstet Gynecol 2009;200:56 e1-6.

7. Chaillet N, Bujold E, Dube E, Grobman WA. Validation of a prediction model for predicting the probability of morbidity related to a trial of labour in quebec. J Obstet Gynaecol Can 2012;34:820-825.

8. Eden KB, McDonagh M, Denman MA, et al. New insights on vaginal birth after cesarean: can it be predicted? Obstet Gynecol 2010;116:967-981.

9. Grobman WA, Lai Y, Landon MB, et al. Development of a nomogram for prediction of vaginal birth after cesarean delivery. Obstet Gynecol 2007;109:806-812.

10. Grobman WA, Lai Y, Landon MB, et al. Does information available at admission for delivery improve prediction of vaginal birth after cesarean? Am J Perinatol 2009;26: 693-701.

11. Costantine MM, Fox K, Byers BD, et al. Validation of the prediction model for success of vaginal birth after cesarean delivery. Obstet Gynecol 2009;114:1029-1033.

12. Costantine MM, Fox KA, Pacheco LD, et al. Does information available at delivery improve the accuracy of predicting vaginal birth after cesarean? Validation of the published models in an independent patient cohort. Am J Perinatol 2011;28: 293-298.

13. Yokoi A, Ishikawa K, Miyazaki K, Yoshida K, Furuhashi M, Tamakoshi K. Validation of the prediction model for success of vaginal birth after cesarean delivery in Japanese women. Int J Med Sci 2012;9:488-491.

14. Menacker F, Declercq E, Macdorman MF. Cesarean delivery: background, trends, and epidemiology. Semin Perinatol 2006;30:235-241.

15. MacDorman M, Declercq E, Menacker F. Recent trends and patterns in cesarean and vaginal birth after cesarean (VBAC) deliveries in the United States. Clin Perinatol 2011;38:179-192.

16. Kwee A, Bots ML, Visser GH, Bruinse HW. Obstetric management and outcome of pregnancy in women with a history of caesarean section in the Netherlands. Eur J Obstet Gynecol Reprod Biol 2007;132:171-176.

17. Montgomery AA, Emmett CL, Fahey $\mathrm{T}$, et al. Two decision aids for mode of delivery among women with previous caesarean section: randomised controlled trial. BMJ 2007;334:1305.

18. Peduzzi P, Concato J, Kemper E, Holford TR, Feinstein AR. A simulation study of the number of events per variable in logistic regression analysis. J Clin Epidemiol 1996;49:1373-1379.

19. Steyerberg EW, Moons KG, van der Windt DA, et al. Prognosis Research Strategy (PROGRESS) 3: prognostic model research. PLoS medicine 2013;10:e1001381. 
EXTERNAL VALIDATION OF VBAC PREDICTION MODELS

20. Kaimal AJ, Kuppermann M. Understanding risk, patient and provider preferences, and obstetrical decision making: approach to delivery after cesarean. Seminars in perinatology 2010;34:331-336. 


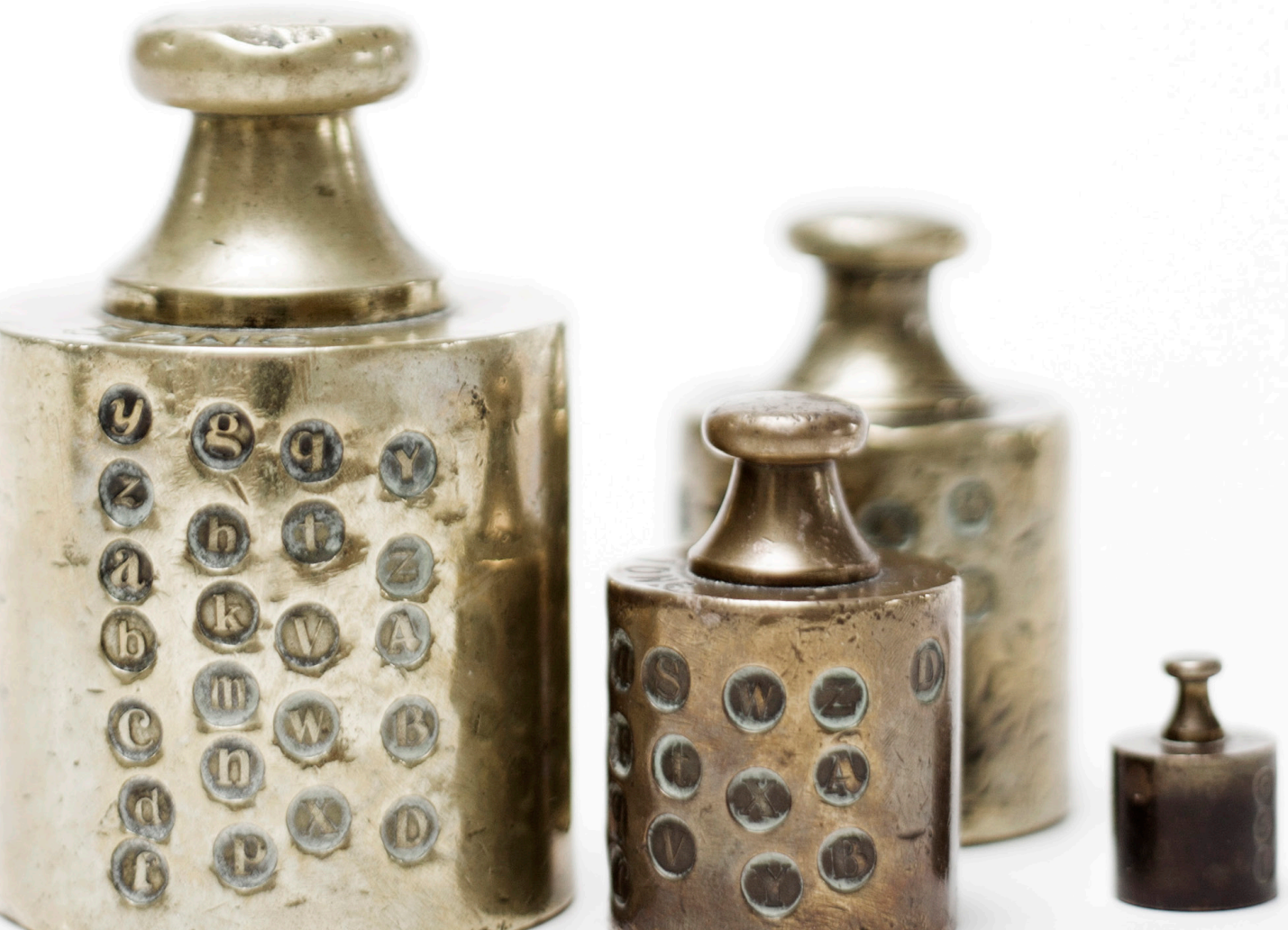


Summary and general discussion 


\section{Summary and general discussion}

This thesis focused on studies to improve caesarean section (CS) care. The main aim was to identify groups of women in whom care was frequently not according to evidence based guidelines and in whom improvement is likely to be (cost) effective and feasible. This was most likely the case in women with a frequently occurring clinical situation and low adherence to CS guideline recommendations. To do so, we firstly defined what optimal CS care was, measured current adherence to this optimal care and assessed which women were most likely to benefit from an improvement strategy. Subsequently, we studied what factors were hindering or helping professionals to provide optimal care and particularly which factors (medical and non-medical) influenced the unplanned (emergency) CS rate in nulliparous women. With these insights a strategy to improve CS care could be developed. In this chapter, the main findings are described and discussed. In addition, implications for clinical practice and future directions for research are given.

\section{Main findings}

- Using the RAND-modified Delphi method, in total, 16 indicators on planned CS and 11 indicators on unplanned (emergency) CS were developed. The indicators on planned CS mainly described clinical situations in which a planned CS is clearly the best option (e.g. placenta previa ), situations in which both a CS and a vaginal delivery are considered reasonable options (e.g. breech presentation), and situations in which a vaginal delivery is the generally accepted policy (e.g. single foetus in cephalic presentation). (Chapter 3)

- The most frequently occurring obstetrical situations with low indicator adherence were: 1) women with a previous CS (frequency 12\%), with adequate counselling in 15\%, 2) suspected foetal distress (frequency 17\%, adherence 46\%), 3) failure to progress (frequency $12 \%$, CS performed too soon in over 75\%), and 4) continuous support during labour (frequency 88\%, adherence 37\%). (Chapter 3)

- Based on evidence based guidelines, barriers and facilitators were explored in all domains. Most barriers were found in the professional and organizational domain. Healthcare professionals mentioned disagreement with specific guideline recommendations and hesitation to allow women to be part of the decision making process as barriers. Also lack of adequately trained personal staff, lack of collaboration between professionals and lack of technical equipment were identified as barriers. (Chapter 4)

- Applying the Robson Ten Group Classification System showed that the major contributors to the CS rate in The Netherlands are not very different from other countries: nulliparous 
women with a singleton in cephalic position after 37 weeks in spontaneous labor (17.1\%), nulliparous women with a singleton in cephalic position after 37 weeks induced or CS before labor (14.2\%), and women with a previous CS (23.8\%). We suggested to apply the SIMPLE quality indicators to the major contributors to the CS rate identified in a Robson Ten-Group analysis. This would allow a more detailed analyses of the CS rate and may identify points for improvement of CS care. (Chapter 5)

- Two prediction models for successful intended vaginal birth after caesarean section (VBAC) developed in the United States were evaluated: the entry to care (ETC) and close to delivery (CTS) model. External validation of these predictive models revealed an adequate performance in the Dutch population. Sixty-seven of the 763 women had an intended VBAC; $72 \%$ of these had an actual VBAC. The discriminative capacity of both the ETC and CTD model were reasonable: 68\% (95\% Cl 63-72\%) and 72\% (95\% Cl 67$76 \%)$, respectively. Analysis of predictive performance showed no lack of fit. (Chapter 6 )

\section{Discussion, implications for clinical practice and future directions}

\section{Women with a previous CS: optimal counselling}

The largest group of women in whom a discussion on mode of delivery (CS or an intention of a vaginal delivery) is important, are women with a previous CS (11\% in our study population). The Dutch guideline dating from before 2010 stated that women need to be informed on their options, the risk of a uterine rupture, as well as the chances of vaginal birth and the increased risk of uterine rupture in case of labour induction. It became clear that only a minority of women were actually counselled and that a majority of these women weren't even offered an option at all [1]. Our study on the hindering factors showed a general reluctance of caregivers to discuss the options since they feared that women would opt for a planned CS and they believed that this would result in a significant rise in the CS rate. This was considered an unwanted effect [2]. A problem with counselling is that the chances of a vaginal birth as described in the guideline are $70-75 \%$ but it is also clear that this differs substantially between women.

We validated two prediction models on successful intended vaginal delivery after prior CS and they proved to have adequate predictive performances [3]. The use of these models can differentiate risk profiles. 
For example: a woman with a BMI of 38, a previous CS due to non-progressing labour and a large baby in the current pregnancy, suggesting the need for labour induction, has a chance of a vaginal delivery of about $32 \%$. On the other hand, a woman with a BMI of 22 , a previous CS due to breech presentation with a normally sized baby, and a spontaneous onset of labour has a chance of a vaginal delivery of about $79 \%$. It is known that morbidity is lowest in women who actually deliver vaginally, but women with a planned CS have lower morbidity than those with an unplanned (emergency) CS. Therefore, the first woman in our example may indeed have lower morbidity when she does not choose to deliver vaginally.

Besides medical risks and benefits, it is likely that women who are involved in their decision making will be more satisfied than those who feel that decisions have been made for them. In our (unpublished) data on women's experiences the feeling not being involved was one of the main reported negative experiences in case of an unplanned CS

The question remains what the effects on involving women in the decision making will be. The use of decision aids has been demonstrated to be helpful and we suggest the development of a decision aid for this specific situation $[4,5]$. Since the chance of an actual successful vaginal delivery after a trial of labour is of the utmost importance for the estimation of risks and benefits, we suggest a prediction model for the Dutch population be developed. The existing models were developed in the United States, based on cohorts in which only a small minority of women actually opt for vaginal delivery $[6,7]$. Therefore, although these models perform adequately, a more specifically designed model may perform better. Furthermore, their models are set in early pregnancy and in early labour. In the Dutch situation, the discussion on mode of delivery usually takes place in the third trimester.

Our hypothesis is that women can be involved in the decision making without a significant rise in the CS rate. We believe that a shift from unplanned to planned CS in case of a low chance of vaginal birth improves outcome and that the Dutch culture of wanting to deliver vaginally is strong and most women do not opt for a planned CS if their chances of delivering vaginally are high. This however, needs to be tested. And even if a rise in de CS rate is observed but women report higher involvement and satisfaction, it can be questioned what the definition of "good outcome" is.

Following the results of this study, a decision aid was developed according to the IDPASS criteria $[8,9]$. Furthermore, a prediction model including the following parameters was developed [10]:

- reason for previous CS non progressing labour: yes/no

- $\mathrm{BMI}$ 
- caucasian ethnicity: yes/no

- labour induction yes/no

- $\quad$ previous vaginal delivery yes/no

- $\quad$ estimated fetal weigth $>$ p90 yes/no

This model was tested in a prospective study and indeed showed that the total number of vaginal deliveries did not change, but a shift from unplanned to planned CS was observed.

\section{Women without a prior CS: Unplanned (emergency) CS}

In the group of women without a previous CS, those who end up with a (possibly unnecessary) CS are mostly nulliparous women with the intention of a vaginal delivery. In total, this group comprises about $40 \%$ of the obstetrical population (SIMPLE study population). Unplanned (emergency) CS occurs mainly in nulliparous women. In multiparous women, occasionally a $\mathrm{CS}$ is performed during labour but this is mainly due to infrequently occurring situations like cord prolapse or instable position of the foetus [11]. It is unlikely that an intervention will substantially change the quality of care in multiparous women.

\section{- Non reassuring foetal condition}

'Suspected foetal distress' is one of the most frequently occurring indicators associated with unplanned CS. Although guidelines in many countries in Europe advise additional testing, e.g. foetal blood sampling (FBS), in case of a non-reassuring foetal heart rate tracing, this is not the case in the United States due to lack of evidence [12-14]. Furthermore, after this study, the results of several STAN analysis trials (i.e., use of foetal ECG) showed no effect on the CS rates. The positive effect of FBS has also only been indirectly demonstrated [15]. Therefore, the lack of evidence, as also mentioned by some caregivers, combined with the fact that FBS is an invasive, technically difficult procedure with a relatively high failure rate, might contribute to its relatively low uptake [3].

Improving guideline adherence may require a more solid proof that this actually reduces CS rates. The use of lactate in case of FBS might reduce the technical difficulties. This is a very promising alternative [16].

\section{- $\quad$ Failure to progress}

The second largest group of women in whom guideline adherence is low is the group of women in which a CS is performed for failure to progress. In our study, in more than $75 \%$ not all recommendations were followed before a CS was performed. In 2010, Wassen et al. described in NTOG that merely $61 \%$ of all hospitals could guarantee epidural 
anaesthesia within one hour [17]. Currently, 24h-availability of epidural anaesthesia is one of the Dutch quality indicators for obstetrical care [18]. A second point of concern in case of failure to progress is, like in the situation of non-reassuring foetal condition, the lack of solid evidence. Although the Friedman chart is used, it dates from the 1950s and the evaluation of outcome is lacking $[19,20]$. The ACOG and RCOG adjusted the recommendations in which an even longer expectative management is advocated $[21,22]$.

As a result of the current data, we started the SIMPLE III study in The Netherlands in which, at the crossing of the Friedman action line, women were randomized between an immediate CS and a longer expectative management. This study was prematurely ended due to failure to include an adequate number of women because of hospitals declining participation. Some hospitals were convinced that prolonged expectative management was absolutely preferable, and others were convinced that an immediate CS was the preferred choice of action. Furthermore, women showed a clear preference for expectative management. More than $90 \%$ of women that refused to be randomized stated that they preferred to wait longer, provided that the foetal condition was reassuring. The next step that will be taken is the development of two prediction models, in which both the chances of vaginal delivery, and the risks for relevant morbidity can be estimated. We are currently studying which morbidity is considered more relevant than a CS by both women and caregivers. The models, possibly combined with a decision aid, can improve counselling and decision making in case of non-progressing labour.

\section{- Continuous support during labour}

The indicator that all women should be offered continuous support during labour was based on a Cochrane review showing a lower CS rate in women who received one on one support and the report 'a good start' by a national steering committee on pregnancy and childbirth in 2009 [23,24]. This is a document advising on improvement of care in the Dutch obstetrical system. Continuous support during labour may improve outcome for women and infants. It is associated with increased spontaneous vaginal birth and shorter duration of labour.

Furthermore, continuous support is reported to decrease CS rate, instrumental vaginal birth, use of any analgesia, use of regional analgesia, low five-minute Apgar score and negative feelings about childbirth experiences. However, the effects might depend on the availability of epidural analgesia, settings where women are not permitted to have companions of their choice during labour, and in middle-income country settings [25]. 
We showed in our study that in a large majority of women continuous support could not be offered by their obstetrical caregivers in hospital births. Barrier analysis showed a lack of adequate staffing to be the main problem [2]. Midwifery-led births might have a higher adherence, but a pilot study on continuous care by the KNOV in 2013 showed that even in first line care, continuous care in the current setting is not feasible due to inadequate availability of caregivers [26]. In the Limburg area we are trying to tackle the problem by a ZONMW funded study by adding "kraamverzorgenden" both in first and second line care to implement continuous care. Although harm is unlikely, the question on cost effectiveness remains relevant.

\section{Methodological considerations}

A strong point of our study is that we included 21 different types of hospitals in several regions in The Netherlands, analysing more than 1000 women per group in order to determine actual care. When comparing the data from our study to data from the Foundation Perinatal Registration The Netherlands (PRN), we conclude that the CS rate is comparable $(22,2 \%$ versus $23,4 \%)$ with a similar distribution of planned and unplanned CS $(11,4 \%, 10,8 \%$ versus $10,5 \%, 12,9 \%$ respectively) [27]. Hence, we expect that the data set is representative for The Netherlands. Furthermore, we applied the RAND-modified Delphi method which offers a systematic approach to indicator development and is a frequently used method that has proven to result in valid quality indicators [28]. We therefore consider the indicator set appropriate for measurement of actual obstetrical practice in the Dutch setting. Its international applicability is questionable since we did not involve international experts when developing the indicator-set. Thus, before applying the indicators internationally, interpretation of the indicator-set by a local expert panel is a necessary step.

A factor that may impair our study is the method of data collection. The data collection from medical charts was performed retrospectively by trained research nurses from the Dutch consortium, which could introduce bias. It was shown by Luck et al. that medical chart review somewhat underestimates the actual care given, thereby underestimating adherence [29]. Not every detail of a consultation is noted in the medical chart. Bias due to misinterpretation from medical charts is a possibility, although data extraction was performed by trained research nurses. However, when considering the adherence percentages for the main categories (fetal distress, non-progressive labour and previous CS) in our study, we do not expect our results to change substantially.

For our barrier analysis study, we invited different types of obstetric healthcare providers that might have an influence on the offered CS care: obstetricians, residents and midwives, respectively. Professionals from different types of hospitals and private practices from 
different Dutch regions participated to this study, thereby representing all different elements of Dutch obstetrical care. The different types of healthcare providers were interviewed separately, in order to let them speak without restraint. The main barriers and facilitators were frequently mentioned among all different types of professionals, suggesting that the identified barriers are useful for the development of a new implementation strategy. Since analysis of interviews is prone to interpretation bias, all interviews were interpreted by two independent reviewers, based on the theoretical model by Grol [30-31]. The influencing factors were identified using a qualitative, explorative method, therefore no quantitative conclusions can be justified by this method.

Our study was performed in a national setting, based on an indicator set developed for measuring Dutch obstetrical practice. Although national and international guidelines formed the basis of the indicator set, we identified some facilitators and barriers that are typical for the Dutch system, concerning the collaboration between first and secondary care. However, it is in line with literature that barriers exist specific to regional habits and practice $[32,33]$. With international guidelines as a basis, we consider most results to be potentially relevant for international use, since our results describe the availability of equipment and staff, acceptance of guidelines and women's motivations to be of influence in line with literature.

The study on external validation of two prediction models was performed in a multicentre setting, with a good representation of different types of hospitals in different regions in The Netherlands. A limitation to our study is the handling of missing data in our data set. There was only a small quantity of missing data for most variables and we considered it to be missing at random. Thus, we were able to limit loss of data by using a multiple imputation strategy. A multiple imputation strategy has shown to be superior to a complete case analysis, because complete case analysis results in a large loss of power and might induce biased parameter estimates $[34,35]$.

\section{Conclusion}

This thesis formed a solid basis for the improvement of care for large groups of women. We were able to define relevant subgroups and develop improvement strategies. Studies on the effects of these strategies are on-going and promising. 


\section{References}

1. Melman S, Schoorel EN, Dirksen C, Kwee A, Smits L et al. SIMPLE: implementation of recommendations from international evidence-based guidelines on caesarean sections in the Netherlands. Protocol for a controlled before and after study. Implement Sci 2013;8:3.

2. Melman S, Schreurs RHP, Dirksen CD, Kwee A, Nijhuis JG, Smeets NAC, Scheepers HCJ, Hermens RPMG. Identification of barriers and facilitators for optimal cesarean section care: perspective of professionals. BMC Pregnancy Childbirth 2017;17:230

3. Schoorel EN, Melman S, van Kuijk SM, Grobman WA, Kwee A et al. Predicting successful intended vaginal delivery after previous caesarean section: external validation of two predictive models in a Dutch nationwide registration-based cohort with a high intended vaginal delivery rate. BJOG 2014;121:840-7.

4. Stacey D, Bennett CL, Barry MJ, Col NF, Eden KB, Holmes-Rovner M et al. Decision aids for people facing health treatment of screening decisions. Cochrane Database Syst Rev 2011;10:CD001431

5. Frost J, Shaw A, Montgomery A, Murphy DJ. Women's views on the use of decision aids for decision making about the method of delivery following a previous caesarean section: qualitative interview study. BJOG 2009;116:896-905.

6. Grobman WA, Lai Y, Landon MB, et al. Development of a nomogram for prediction of vaginal birth after cesarean delivery. Obstet Gynecol 2007;109:806-812.

7. 10. Grobman WA, Lai Y, Landon MB, et al. Does information available at admission for delivery improve prediction of vaginal birth after cesarean? Am J Perinatol 2009;26: 693-701.

8. Elwyn G, O’Connor A, Stacey D, Volk R, Edwards A, Coulter A, et al. Developing a quality criteria framework for patient decision aids: online international Delphi consensus process. BMJ 2006;333:417.

9. Elwyn G, O'Connor AM, Bennett C, Newcombe RG, Politi M, Durand MA, et al. Assessing the quality of decision support technologies using the International Patient Decision Aid Standards instrument (IPDASi). PLoS One 2009;4:e4705.

10. Schoorel EN, van Kuijk SM, Melman S, Nijhuis JG, Smits LJ et al. Vaginal birth after a caesarean section: the development of a Western European population-based prediction model for deliveries at term. BJOG 2014;121:194-201.

11. Melman S, Schoorel EC, de Boer K, Burggraaf H, Derks JB et al. Development and Measurement of Guidelines-Based Quality Indicators of Caesarean Section Care in the Netherlands: A RAND-Modified Delphi Procedure and Retrospective Medical Chart Review. PLoS One 2016;11:e0145771.

12. NICE Guidance. Quality statement 7: The use of fetal blood sampling.

13. NVOG-richtlijn Intrapartum foetale bewaking à terme. 14-11-2013.

14. ACOG Practice Bulletin No. 106: Intrapartum fetal heart rate monitoring: nomenclature, interpretation, and general management principles. Obstet Gynecol 2009;114:192-202.

15. Amer-Wahlin I, Kwee A. Combined cardiotocographic and ST event analysis: a review. Best Pract Res Clin Obstet Gynaecol 2016;30: 48-61.

16. East CE, Leader LR, Sheehan P, Henshall NE, Colditz PB, Lau R. Intrapartum fetal scalp lactate sampling for fetal assessment in the presence of a non-reassuring fetal heart rate trace. Cochrane Databse Syst Rev 2015;1:CD006174.

17. Wassen M.M.L.H., Buijs C, Nijhuis JG. Beschikbaarheid epidurale analgesie tijdens de bevalling in Nederland anno 2010. NTOG 2010;10:397-399. 
18. Zorginstituut Nederland. Indicatorset Integrale Geboortezorg Verslagjaar 2019. Indicatorgids 21-1-2019.

19. Friedman, E. The graphic analysis of labor. Am J Obstet Gynaecol 1954;68:1568-1571.

20. Albers LL. The duration of labor in healthy women. J. Perinatol 1999;19:114-119.

21. Cheng YW, Caughey AB. Defining and managing normal and abnormal second stage of labor. Obstet Gynecol Clin North Am 2017;44:547-566.

22. NICE Guidance. Clinical guideline [CG190]: Intrapartum care for healthy women and babies. February 2017.

23. Hodnett ED, Gates S, Hofmeyr GJ, Sakala C. Continuous support for women during childbirth. Cochrane Databse Syst Rev 2007;3:CD003766.

24. Stuurgroep zwangerschap en geboorte. Een goed begin. Veilige zorg rond zwangerschap en geboorte. December 2009.

25. Bohren MW, Hofmeyr GJ, Sakala C, Fukuzawa RK, Cuthbert A. Continuous support for women during childbirth. Cochrane Databse Syst Rev 2017;7:CD003766.

26. Knov.nl: Verslag pilot 'Continue begeleiding tijdens de baring' 2013.

27. Perinatal Care in The Netherlands 2010. Utrecht: Foundation Perinatal Registration The Netherlands (PRN), 2013.

28. Kötter T, Eva Blozik E, Scherer M. Methods for the guideline-based development of quality indicators-a systematic review. Impl Science 2012;7:21

29. Luck J, Peabody JW, Dresselhaus TR, Lee M, Glassman P. How well does chart abstraction measure quality? A prospective comparison of standardized patients with the medical record. Am J Med 2000;108:642-9.

30. Grol R. Beliefs and evidence in changing clinical practice. BMJ. 1997;315:418-421.

31. Grol R. Improving the quality of medical care: building bridges among professional pride, payer profit, and patient satisfaction. JAMA 2001;286:2578-2585.

32. Chaillet N, Dube E, Dugas M, Francoeur D, Dube J, Gagnon S et al. Identifying barriers and facilitators towards implementing guidelines to reduce caesarean section rates in Quebec. Bulletin of the World Health Organization 2007;85:791-797.

33. Yazdizadeh B, Nedjat S, Mohammad K, Rashidian A, Changizi N, Majdzadeh R. Cesarean section rate in Iran, multidimensional approaches for behavioral change of providers: a qualitative study. BMC Health Serv Res 2011;11:159.

34. Steyerberg EW, Clinical Predication Models. New York NS.

35. Donders AR, van der Heijden GJ, Stijnen T, Moons KG. Review: a gentle introduction to imputation of missing values. J Clin Epidemiol 2006;59:1087-1091. 

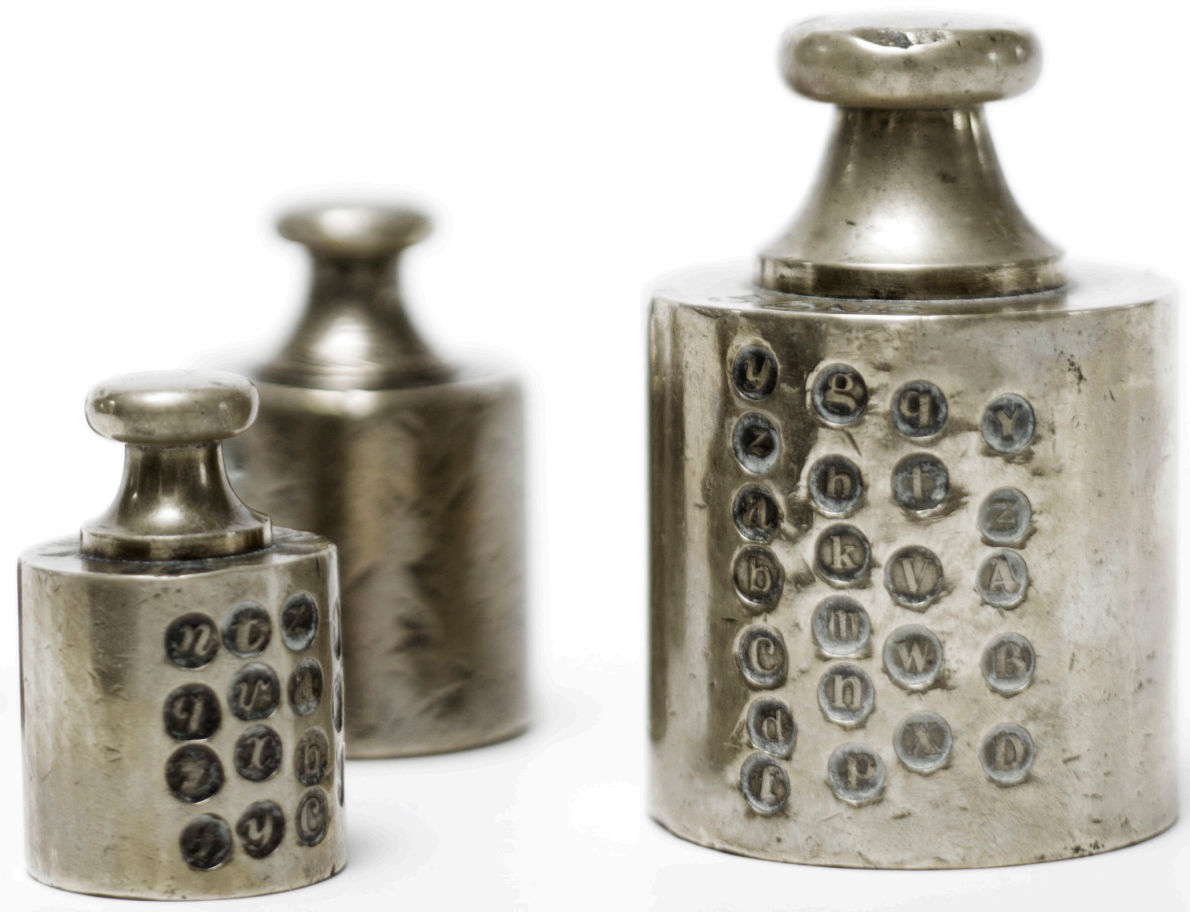
Valorisatie

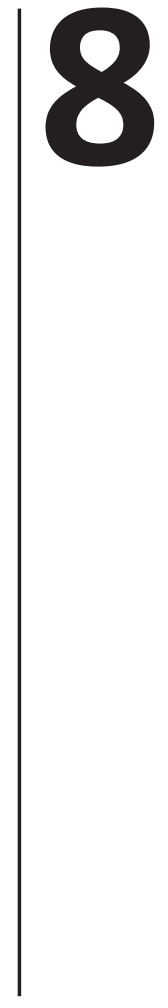




\section{Valorisatie}

Dit hoofdstuk beschrijft het maatschappelijk belang van de onderzoeken uit dit proefschrift en hoe deze van invloed zijn op de zwangere in het bijzonder.

\section{Relevantie}

Wereldwijd wordt een stijging van het aantal keizersneden waargenomen. In Nederland is het percentage keizersneden de laatste jaren stabiel rond de $15 \%$. Hierbij is echter opvallend dat de meeste keizersneden plaatsvinden bij de 'gezonde' zwangere: vrouwen zwanger van hun eerste kind in hoofdligging na 37 weken [1,2]. Deze stijging gaat niet gepaard met een verbeterde gezondheid voor moeder of kind, sterker nog, de keizersnede heeft ook nadelen. Ten opzichte van een vaginale baring leidt een keizersnede tot een toegenomen kans op complicaties, niet alleen voor de huidige, maar ook voor een daarop volgende zwangerschap [3-6]. Daarnaast zijn de kosten van een keizersnede hoger dan de kosten van een vaginale baring.

\section{Doelgroep}

Zowel de Nederlandse Vereniging voor Obstetrie en Gynaecologie (NVOG) als andere internationale verenigingen hebben richtlijnen opgesteld, waarin de indicaties voor een keizersnede worden beschreven. Het is echter de vraag of deze richtlijnen voldoende gevolgd worden. In hoofdstuk 3 staat het proces beschreven van de ontwikkeling van kwaliteitsindicatoren rondom een keizersnede. De kwaliteitsindicatoren hebben niet alleen betrekking op de indicatiestelling voor een keizersnede, maar ook op maatregelen die de kans op een keizersnede verkleinen. Deze indicatoren staan voor optimale zorg en maken deze daadwerkelijk meetbaar. Vervolgens is aan de hand van de kwaliteitsindicatoren de huidige zorg gemeten. Uit de analyse blijkt dat de adviezen uit de kwaliteitsindicatoren niet altijd gevolgd worden. Hierbij zijn 4 groepen zwangere vrouwen naar voren gekomen, waarbij de kwaliteitsindicator frequent voorkomt en de naleving van de kwaliteitsindicator relatief laag is:

1. Vrouwen met een voorgaande keizersnede

2. Vrouwen zwanger van een eerste kind met vermoeden op foetale nood

3. Vrouwen zwanger van een eerste kind waarbij de baring niet vordert

4. Continue begeleiding van de baring

De verwachting is dat een verbeterstrategie gericht op deze 4 groepen de grootste invloed heeft op de mogelijke verbetering van de zorg. Omdat de gegevens van meerdere ziekenhuizen zijn geanalyseerd, is dit onderzoek representatief voor de Nederlandse bevolking. Daarmee is 
te verwachten dat de verbeteringen van invloed zijn op alle Nederlandse zwangere vrouwen. In hoofdstuk 5 beschrijven we de classificatie van de SIMPLE studie populatie volgens het classificatie systeem van Robson [7]. Dit systeem maakt gebruik van 10 groepen, waarin alle zwangere vrouwen kunnen worden ingedeeld. Het doel van een dergelijke indeling is om vergelijking van keizersnede percentages tussen ziekenhuizen, regio's of landen mogelijk te maken. Bij de indeling komen twee groepen naar voren die de grootste bijdrage leveren aan het percentage keizersneden:

A. Vrouwen zwanger van een eerste kind in hoofdligging vanaf $37+0$ weken;

B. Vrouwen met een eerdere keizersnede in het verleden.

Het voorkómen van de eerste keizersnede en de juiste voorlichting aan de zwangere met een eerdere keizersnede zijn daarom van groot belang. In hetzelfde hoofdstuk staat een voorstel beschreven om inhoud toe te voegen aan de vergelijking van keizersnede percentages. Als duidelijk is dat de twee bovenstaande groepen de belangrijkste bijdrage leveren aan het percentage keizersneden, kunnen kwaliteitsindicatoren van de SIMPLE studie worden toegevoegd aan de analyse. Zodoende omvat de analyse de volgende groepen:

A. Het percentage vrouwen met een eerste kind in hoofdligging vanaf $37+0$ weken waarbij een ongeplande keizersnede wordt uitgevoerd vanwege niet vorderen van de baring waarbij sprake is van:

- Gebroken vliezen, adequate pijnstilling en adequate contracties gedurende 4 uur

- Actief persen in het stadium van de uitdrijving, en indien mogelijk een kunstverlossing is aangeboden;

B. Het percentage vrouwen met één voorgaande keizersnede en een eenling in hoofdligging vanaf $37+0$ weken die adequaat voorgelicht zijn over alle voor- en nadelen van een geplande keizersnede en vaginale baring na een eerdere keizersnede en een keuze hadden in de manier van bevallen.

Door de toevoeging van kwaliteitsindicatoren aan het classificatiesysteem van Robson is niet alleen internationale vergelijking van keizersnede percentages mogelijk, maar is ook vergelijking van de inhoud van de zorg mogelijk. Als uit een dergelijke analyse blijkt dat het percentage keizersneden verhoogd is, kan, na analyse van factoren die van invloed zijn op de zorg, een verbeterstrategie worden ontwikkeld. Door deze aanpak kan de zorg voor zwangere vrouwen internationaal worden bevorderd.

\section{Innovatie}

De SIMPLE studie is de eerste studie die een set kwaliteitsindicatoren heeft ontwikkeld met 
betrekking tot het gehele verloskundige proces rondom de keizersnede. Hierbij zijn zowel de indicatiestelling beschreven, als maatregelen die de kans op een keizersnede verlagen. Doordat factoren worden meegenomen die voor aanvang van de bevalling van invloed zijn op de besluitvorming (bv stuitligging), tijdens een bevalling (bv niet vorderen van de baring), en na de bevalling (bv het opzetten van een audit mbt keizersneden), kan de kwaliteit van het hele zorgproces worden gemeten. Tevens zijn factoren bepaald die belemmerend of bevorderend kunnen werken bij het volgen van de kwaliteitsindicatoren, zodat het mogelijk is om een aangepaste verbeteringsstrategie te ontwikkelen.

\section{Implementatie}

De implementatie wordt beschreven aan de hand van de 4 groepen van zwangere vrouwen die zijn geïdentificeerd in hoofdstuk 3 van dit onderzoek.

\section{Vrouwen met een voorgaande keizersnede}

De Nederlandse richtlijn gaf aan dat vrouwen met een voorgaande keizersnede geïnformeerd dienen te worden over hun keuze, de kans op complicaties, zoals een scheur in de baarmoeder en de kans op succesvolle vaginale baring. In hoofdstuk 4 staat beschreven dat zorgverleners terughoudend zijn om vrouwen te betrekken bij deze beslissing uit vrees voor een toename in het percentage keizersneden. Een nadeel van deze voorlichting is dat wordt uitgegaan van een algemeen slagingspercentage voor vaginale baring na een eerdere keizersnede. In hoofdstuk 6 staat de validatie van 2 voorspellingsmodellen beschreven, die een individuele kans van slagen geven, rekening houdend met persoonlijke kenmerken. Dit geeft een betere risicoselectie voorafgaand aan de baring. Deze modellen hebben een goed voorspellend vermogen, echter het is noodzakelijk om het model te valideren in een prospectieve studie. Daarnaast is het opstellen van een keuzehulp een volgende stap om de voorlichting voor vrouwen na een eerder keizersnede te verbeteren. De combinatie van gestandaardiseerde voorlichting middels een keuzehulp die leidt tot een geïndividualiseerde inschatting van de kans van slagen van een vaginale baring na een keizersnede kan voordelen bieden voor zorgverlener en zwangere. Het effect op de zwangerschapsuitkomst, evenals de tevredenheid van zorgverlener en patiënt is in een prospectief onderzoek bestudeerd [8]. Hierbij is een gelijk percentage keizersnede waargenomen, met een verschuiving van ongeplande keizersneden naar geplande keizersneden. Dit wijst op een betere risicoselectie voorafgaand aan de baring.

\section{Vrouwen zwanger van een eerste kind met vermoeden op foetale nood}

Alhoewel richtlijnen aanvullende diagnostiek in de vorm van microbloedonderzoek of STAN analyse adviseren, is er onvoldoende bewijs voor een verbeterde uitkomst. Na 
de totstandkoming van de kwaliteitsindicatoren uit dit onderzoek, tonen diverse trials dat het gebruik van STAN geen invloed heeft op het percentage keizersneden dat wordt uitgevoerd. Voor het positieve effect van microbloedonderzoek bestaat slechts indirect bewijs [9-12]. Het gebrek aan bewijsvoering in combinatie met een tijdrovende, invasieve en technisch ingewikkelde procedure kan een verklaring zijn voor de lage adherentie. Om de naleving van deze kwaliteitsindicator te verbeteren is een onderzoek naar de effectiviteit van het microbloedonderzoek noodzakelijk. De toepassing van lactaat analyse bij het microbloedonderzoek kan de procedure vergemakkelijken [13]. Hierbij is een kleinere hoeveelheid bloed nodig, waardoor de kans van slagen mogelijk toeneemt. Een combinatie van verbeterde bewijsvoering en een eenvoudiger procedure kan de zorg in geval van verdenking foetale nood verbeteren.

\section{Vrouwen zwanger van een eerste kind waarbij de baring niet vordert}

Om de zorg voor deze groep zwangere vrouwen te verbeteren wordt adequate pijnstilling geadviseerd. De beschikbaarheid van de ruggenprik 24 uur per dag is een Nederlandse kwaliteitsindicator voor Medisch Specialistische Zorg [14]. Ook in het geval van deze indicator is er onvoldoende bewijsvoering wat betreft de diagnose 'niet vorderen van de baring'. De Friedman curve die wordt gebruikt om de vordering van de baring in kaart te brengen dateert uit 1950 en is onvoldoende gevalideerd $[15,16]$. De gynaecologen verenigingen in Groot-Brittannië en de Verenigde Staten promoten een langere periode van afwachten onder optimale condities dan bij de Friedman curve $[17,18]$. Naar aanleiding van deze gegevens is een volgende SIMPLE studie gestart die vrouwen in geval van niet vorderen van de baring randomiseert tussen een keizersnede en een verlenging van de periode waarin wordt afgewacht. Deze studie is tussentijds beëindigd vanwege een gebrek aan inclusies. Hieraan lag ten grondslag dat diverse zorgverleners en patiënten een specifieke voorkeur uitspraken voor een keizersnede of een afwachtend beleid. Meer dan 90\% van de vrouwen gaf aan de voorkeur te geven aan een afwachtend beleid zolang er sprake was van een goede foetale conditie. Als volgende stap zou de ontwikkeling van een voorspellingsmodel voor de kans van slagen van een vaginale baring in geval van niet vorderen van de baring een toevoeging zijn. Dit model, wellicht in combinatie met een keuzehulp waarin de kans op morbiditeit wordt beschreven, kan zorgverleners en patiënten helpen bij het maken van hun keuze.

\section{Continue begeleiding van de baring}

Continue begeleiding van vrouwen tijdens de baring wordt geadviseerd in het rapport 'een goed begin', opgesteld door een nationale Stuurgroep Zwangerschap en Geboorte [19]. Continue begeleiding verkleint de kans op een keizersnede en een vaginale kunstverlossing. Daarbij is aangetoond dat de pijnstillingsbehoefte afneemt en de 
zwangere positiever terugkijkt op haar bevalling [20]. Een gebrek aan personeel en financiën zijn de grootste belemmeringen voor het uitvoeren van deze kwaliteitsindicator. In Limburg is een zonMW studie gestart waarbij kraamverzorgenden worden ingezet voor continue begeleiding tijdens de baring. Hierbij wordt gerandomiseerd tussen gebruikelijke zorg en continue begeleiding van de barende en wordt het effect op onder andere pijnstillingsbehoefte en percentage keizersneden beoordeeld. Daarnaast wordt de kosteneffectiviteit beoordeeld.

Met deze studie is een basis gelegd voor verbetering van zorg voor zwangere vrouwen. Er zijn diverse projecten opgestart om de effecten van de implementatiestrategieën te evalueren. 


\section{Referenties}

1. Macfarlane AJ, Blondel B, Mohangoo AD, Cuttini M, Nijhuis J, Euro-Peristat Scientific Committee. Wide differences in mode of delivery within Europe: risk-stratified analyses of aggregated routine data from the Euro-Peristat study. BJOG 2016;123:559-68.

2. Kwee A, Elferink-Stinkens PM, Reuwer PJHM, Bruinse HW. Trends in obstetric interventions in the Dutch obstetrical care system in the period 1993-2002. Eur J Obstet Gynecol Reprod Biol 2007;132:70-75.

3. Ananth CV, Smulian JC, Vintzileos AM. The association of placenta previa with a history of cesarean delivery and abortion: A meta-analysis. Am J Obstet Gynecol 1997;177:1071-1078.

4. Zwart JJ, Richters JM, Öry F, Vries de JIP, Bloemenkamp KWM, Roosmalen van J. Uterine rupture in the Netherlands: a nationwide population-based cohort study. BJOG 2009;116:1069-1080.

5. Liu S, Liston RM, Joseph KS, Heaman M, Sauve R, Kramer MS, for the Maternal Health Study Group of the Canadian Perinatal Surveillance System. Maternal mortality and severe morbidity associated with low-risk planned caesarean delivery versus planned vaginal delivery at term. CMJH 2007;176:455-460

6. Lumbiganon P, Laopaiboon M, Gülmezoglu AM, Souza JP, Taneepanichskul S, Ruyan P, et al. World Health Organization Global Survey on Maternal and Perinatal Health Research Group: Method of delivery and pregnancy outcomes in Asia: the WHO global survey on maternal and perinatal health 2007-08. Lancet 2010;375:490-499.

7. Robson MS: Can we reduce the caesarean section rate? Best Pract Res Clin Obstet Gynaecol 2001, 15:179-194.

8. Schoorel EN, Vankan E, Scheepers HC, Augustijn BC, Dirksen CD et al. Involving women in personalised decisionmaking on mode of delivery after caesarean section: the development and pilot testing of a patient decision aid. BJOG 2014;121:202-9.

9. NICE Guidance. Quality statement 7: The use of fetal blood sampling.

10. NVOG-richtlijn Intrapartum foetale bewaking à terme. 14-11-2013.

11. ACOG Practice Bulletin No. 106: Intrapartum fetal heart rate monitoring: nomenclature, interpretation, and general management principles. Obstet Gynecol 2009;114:192-202.

12. Amer-Wahlin I, Kwee A. Combined cardiotocographic and ST event analysis: a review. Best Pract Res Clin Obstet Gynaecol 2016;30: 48-61

13. East CE, Leader LR, Sheehan P, Henshall NE, Colditz PB, Lau R. Intrapartum fetal scalp lactate sampling for fetal assessment in the presence of a non-reassuring fetal heart rate trace. Cochrane Databse Syst Rev 2015;1:CD006174.

14. Zorginstituut Nederland. Indicatorset Integrale Geboortezorg Verslagjaar 2019. Indicatorgids 21-1-2019.

15. Friedman, E. The graphic analysis of labor. Am J Obstet Gynaecol 1954;68:1568-1571.

16. Albers LL. The duration of labor in healthy women. J. Perinatol 1999;19:114-119.

17. Cheng YW, Caughey AB. Defining and managing normal and abnormal second stage of labor. Obstet Gynecol Clin North Am 2017; 44:547-566

18. NICE Guidance. Clinical guideline [CG190]: Intrapartum care for healthy women and babies. February 2017.

19. Stuurgroep zwangerschap en geboorte. Een goed begin. Veilige zorg rond zwangerschap en geboorte. December 2009.

20. Bohren MW, Hofmeyr GJ, Sakala C, Fukuzawa RK, Cuthbert A. Continuous support for women during childbirth. Cochrane Databse Syst Rev 2017;7:CD003766. 


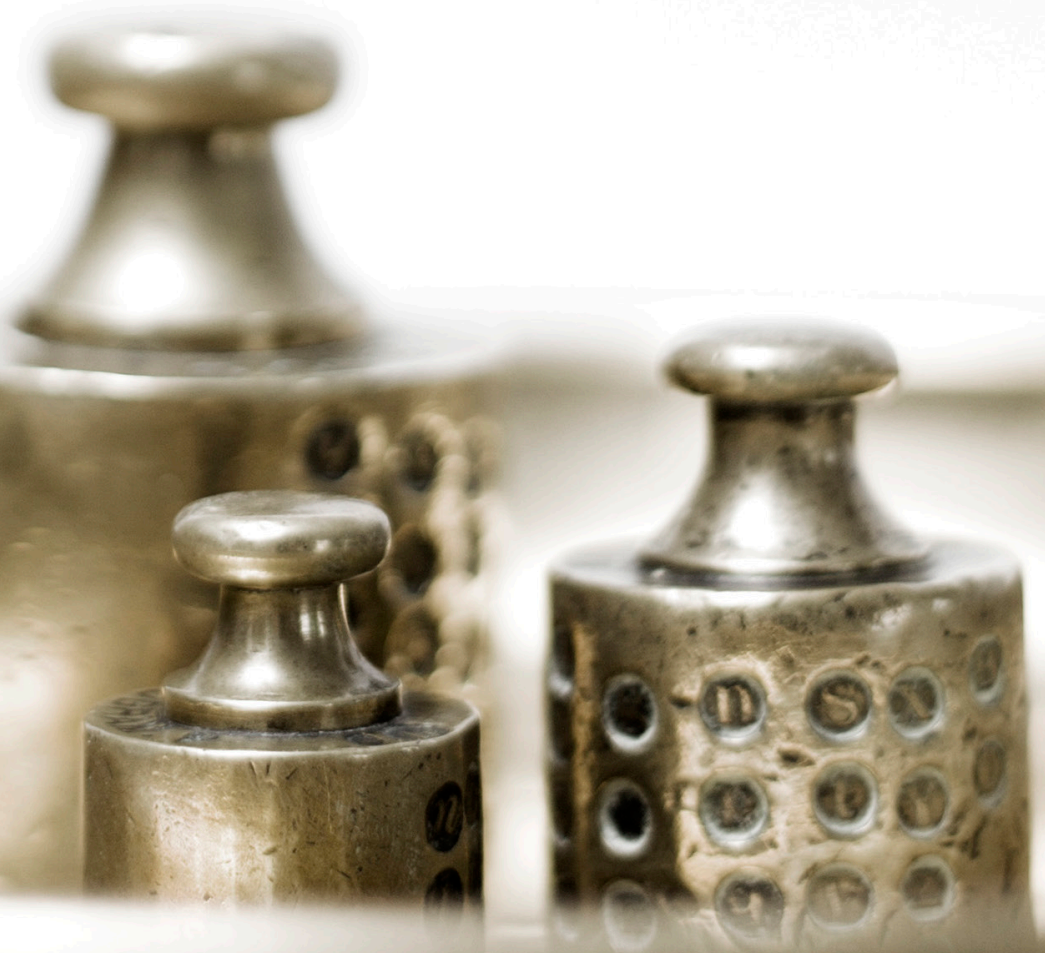


Nederlandstalige samenvatting

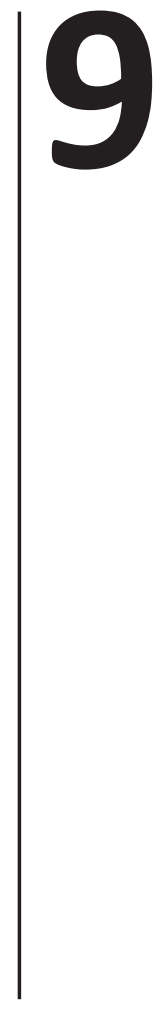




\section{Nederlandstalige samenvatting}

\section{Achtergrond en doel van het onderzoek}

De keizersnede (sectio caesarea: SC) is bedoeld als levensreddende operatie voor moeder en kind. Er zijn richtlijnen ontwikkeld die aangeven voor welke indicaties deze ingreep kan worden uitgevoerd. De wereldwijde stijging van het SC percentage en de variatie daarin kan erop wijzen dat deze operatie niet altijd juist wordt ingezet. Een SC heeft gevolgen voor een volgende zwangerschap en gaat gepaard met hogere kosten.

Dit proefschrift richt zich op verbetering van zorg rondom de SC. Het doel van dit onderzoek was om groepen vrouwen te identificeren, waar de zorg in hoge mate niet in lijn was met wetenschappelijke richtlijnen en waar verbetering van zorg waarschijnlijk (kost)effectief en haalbaar is. Hiertoe is allereerst optimale zorg rondom de SC gedefinieerd obv richtlijnen. Vervolgens is de naleving van optimale zorg gemeten en bepaald welke groep vrouwen meest waarschijnlijk baat zou hebben bij een verbeteringsstrategie. In de volgende stap is bepaald welke factoren bijdragen aan het bevorderen of belemmeren van optimale zorg en met name welke (medische en niet-medische) factoren de kans op een ongeplande (spoed) SC bij nullipare vrouwen beïnvloeden. Met deze inzichten zijn strategieën ontwikkeld om de zorg rondom de SC te verbeteren. Deze stappen worden in dit hoofdstuk beschreven.

\section{Belangrijkste bevindingen}

Hoofdstuk 1 bevat een algemene introductie en een uiteenzetting van de inhoud van dit proefschrift. De SC is wereldwijd een van de meest uitgevoerde operaties bij vrouwen. Hoewel ooit als levensreddende ingreep ingevoerd, wordt nu bediscussieerd dat de toegenomen incidentie mogelijk een negatief effect op de gezondheid van moeder en kind kan hebben.

Hoofdstuk 2 beschrijft het studie protocol van de SIMPLE studie (cesarean Section IMPLEmentation) met de volgende onderwerpen: 1) De ontwikkeling van kwaliteitsindicatoren rondom de besluitvorming tot een SC, gebaseerd op kernaanbevelingen van nationale en internationale richtlijnen; 2) het gebruik van deze indicatoren om inzicht te krijgen in de mate waarin zorgverleners in de dagelijkse praktijk werken volgens de richtlijnen (richtlijnadherentie); 3) het bepalen van belemmerende en bevorderende factoren die de richtlijnadherentie beïnvloeden; 4) het ontwikkelen, uitvoeren en evalueren van een strategie om de richtlijnadherentie te verbeteren. Met de uitkomsten van de studie worden groepen vrouwen geïdentificeerd waarbij een interventiestrategie om de zorg te verbeteren (kost) effectief en haalbaar zal zijn. In de hoofdstukken 3 en 4 worden de studies, gericht op de eerste 3 onderwerpen, uitgebreid beschreven. Het ontwikkelen van een interventie-strategie vormt geen onderdeel van dit proefschrift. 
Hoofdstuk 3 beschrijft de ontwikkeling en meting van op de richtlijnen gebaseerde kwaliteitsindicatoren rondom de SC zorg in Nederland. Achttien gynaecologen en verloskundigen vormen een expertpanel waarbij een systematische ontwikkeling van indicatoren volgens de RAND-modified Delphi methode is verricht. In een multicenter onderzoek zijn de indicatoren gemeten aan de hand van dossiers van 1024 vrouwen met een SC en een gestratificeerde en gewogen random geselecteerde groep van 1036 vrouwen met een vaginale baring. Zowel het voorkomen van de situatie (bv. stuitligging, niet vorderen van de baring), zoals beschreven in de kwaliteitsindicatoren (frequentie) als de adherentie aan de indicatoren zijn bepaald. In totaal zijn 16 indicatoren rondom een geplande SC en 11 indicatoren rondom een ongeplande SC ontwikkeld en gemeten. Adherentie is gedefinieerd als het percentage vrouwen waarbij de zorg zoals beschreven in de indicator daadwerkelijk is verleend. De meest voorkomende groepen met een lage adherentie zijn: 1) verdenking foetale nood (frequentie voorkomen $17 \%$, adherentie $46 \%$ ), 2) niet vorderende baring (frequentie voorkomen $12 \%$, keizersnede te vroeg ingezet $>75 \%$ ), 3) continue begeleiding tijdens de baring (frequentie voorkomen $88 \%$, adherentie 37\%) 4) vrouwen met een eerdere SC (frequentie voorkomen 12\%, adherentie adequate counseling 15\%).

Hoofdstuk 4 beschrijft de belemmerende en bevorderende factoren rondom SC zorg vanuit het perspectief van de zorgverlener. Zowel focusgroep interviews als telefonische interviews onder 29 verschillende obstetrische zorgverleners zijn verricht. De factoren zijn geïdentificeerd en gecategoriseerd in zes domeinen volgens het framework van Grol \& Wensing: de richtlijn zelf, de professional, de patiënt, de sociale context, de organisatorische context en de financiële/juridische context. De meeste belemmerende factoren zijn in het professionele en organisatorische domein gevonden. Zorgverleners kunnen zich op sommige onderdelen van de richtlijn niet in de inhoud vinden en er bestond aarzeling om vrouwen deel te laten nemen aan het besluitvormingsproces. Overige belemmerende factoren betreffen een gebrek aan getraind personeel, onvoldoende samenwerking tussen zorgverleners uit verschillende disciplines en een gebrek aan materieel. Een aantal belemmerende factoren kan worden opgelost door de ontwikkeling van een keuzehulp en/of een predictiemodel om de zorg te individualiseren voor vrouwen waarbij een SC en een vaginale baring beiden tot de mogelijkheden behoren. Bij vrouwen die aan een vaginale baring beginnen, is voldoende personeel voor begeleiding en epidurale pijnstilling belangrijk.

Hoofdstuk 5 beschrijft het SC percentage van de SIMPLE studie populatie na indeling volgens het classificatie systeem van Robson. Dit systeem omvat 10 obstetrische groepen waarin alle zwangere vrouwen kunnen worden ingedeeld om het SC percentage per groep te bepalen. Dit maakt vergelijking van SC percentages mogelijk per ziekenhuis, regio of land. De subgroepen met de belangrijkste bijdrage aan het SC percentage zijn: 1) nullipare vrouwen met een 
eenling in hoofdligging na 37 weken, 2) vrouwen met een voorgaande SC met een eenling in hoofdligging na 37 weken en 3) vrouwen met een inleiding of geplande SC (bijdrage aan SC percentage respectievelijk 17\%, 24\% en 14\%). Dit geeft aan dat het voorkomen van de eerste SC van groot belang is. Dit classificatie systeem is hiermee een eerste indicatie voor de identificatie van subgroepen met een (relatief) hoog SC percentage. Om meer inhoud aan de vergelijking van SC percentages in deze groepen te bewerkstelligen, is ons voorstel om een analyse van SIMPLE kwaliteitsindicatoren toe te voegen aan de groepen die het meest bijdragend zijn aan het SC percentage.

Hoofdstuk 6 beschrijft de externe validatie van twee predictiemodellen ontwikkeld in de Verenigde Staten voor vrouwen na een eerdere SC om de kans op een geslaagde vaginale baring te voorspellen. In een cohort van 763 vrouwen met één SC in het verleden en een eenling in hoofdligging in de huidige zwangerschap zonder contra-indicatie voor een vaginale baring zijn twee bestaande modellen gevalideerd voor de Nederlandse populatie: het entry-to-care [ETC] en close-to-delivery [CTD] model. Het ETC model bevat de variabelen leeftijd, BMI, etniciteit, eerdere vaginale bevalling, eerdere vaginale bevalling na een SC en een voorgeschiedenis van een niet vorderende baring. Het CTD model vervangt de BMI voorafgaand aan de zwangerschap door de BMI in het derde trimester en voegt geschatte zwangerschapsduur bij de bevalling toe, evenals de variabelen hypertensie, cervixstatus en inleiding. Met beide modellen is de kans op een succesvolle vaginale baring na eerdere SC berekend voor de 763 vrouwen. Vijfhonderdvijftien (67\%) van de 763 vrouwen hadden een intentie tot een vaginale baring; 371 (72\%) van hen bevielen vaginaal. Vervolgens is gekeken naar het voorspellend vermogen (precisie) en onderscheidend vermogen (onderscheid tussen hoge versus lage kans van slagen) om te beoordelen hoe de modellen in dit Nederlandse cohort presteren. De area under the curve (AUC) van het ETC en CTD model zijn respectievelijk 68\% (95\% Cl 63-72\%) en 72\% (95\% Cl 67-76\%), wat een redelijk onderscheidend vermogen aangeeft. De Hosmer-Lemeshow toets laat een P-waarde van 0.17 voor het ETC model en 0.36 voor het CTD model zien, doelend op een redelijke precisie. Dit toont aan dat beide modellen adequaat presteren in ons Nederlandse cohort.

Hoofdstuk 7 beschrijft de algemene discussie van dit proefschrift en biedt suggesties voor toekomstig onderzoek. We stellen dat dit proefschrift een basis vormt voor verbetering van zorg voor een grote groep vrouwen. We zijn in staat geweest om groepen vrouwen te definiëren waar verbetering van zorg mogelijk is en verbeteringsstrategieën ontwikkeld worden. De studies naar het effect van deze strategieën zijn veelbelovend. 
$2 x+x \times x$ 
Publications and Presentations

Dankwoord

Curriculum vitae 


\section{Publications and Presentations}

\section{Publications}

Melman S, Schoorel EN, Dirksen C, Kwee A, Smits L et al. , de Boer F, Jonkers M, Woiski MD, Mol BW, Doornbos JP, Visser H, Huisjes AJ, Porath MM, Delemarre FM, Kuppens SM, Aardenburg R, Van Dooren IM, Vrouenraets FP, Lim FT, Kleiverda G, van der Salm PC, de Boer K, Sikkema MJ, Nijhuis JG, Hermens RP, Scheepers HC.

SIMPLE: implementation of recommendations from international evidence-based guidelines on caesarean sections in the Netherlands. Protocol for a controlled before and after study. Implement Sci. 2013;8:3.

Melman S, Schoorel EC, de Boer K, Burggraaf H, Derks JB, van Dijk D, van Dillen J, Dirksen CD, Duvekot JJ, Franx A, Hasaart TH, Huisjes AJ, Kolkman D, van Kuijk S, Kwee A, Mol BW, van Pampus MG, de Roon-Immerzeel A, van Roosmalen JJ, Roumen FJ, Smid-Koopman E, Smits L, Spaans WA, Visser H, van Wijngaarden WJ, Willekes C, Wouters MG, Nijhuis JG, Hermens RP, Scheepers HC.

Development and Measurement of Guidelines-Based Quality Indicators of Caesarean Section Care in the Netherlands: A RAND-Modified Delphi Procedure and Retrospective Medical Chart Review.

PLoS One 2016;11:e0145771.

Melman S, Schreurs RHP, Dirksen CD, Kwee A, Nijhuis JG, Smeets NAC, Scheepers HCJ, Hermens RPMG.

Identification of barriers and facilitators for optimal cesarean section care: perspective of professionals.

BMC Pregnancy Childbirth. 2017;17:230.

Schoorel EN, Melman S, van Kuijk SM, Grobman WA, Kwee A, Mol BW, Nijhuis JG, Smits LJ, Aardenburg R, de Boer K, Delemarre FM, van Dooren IM, Franssen MT, Kleiverda G, Kaplan M, Kuppens SM, Lim FT, Sikkema JM, Smid-Koopman E, Visser H, Vrouenraets FP, Woiski M, Hermens RP, Scheepers HC.

Predicting successful intended vaginal delivery after previous caesarean section: external validation of two predictive models in a Dutch nationwide registration-based cohort with a high intended vaginal delivery rate.

BJOG 2014;121:840-7.

Schoorel EN, Vankan E, Scheepers HC, Augustijn BC, Dirksen CD, de Koning M, van Kuijk SM, Kwee A, Melman S, Nijhuis JG, Aardenburg R, de Boer K, Hasaart TH, Mol BW, Nieuwenhuijze 
M, van Pampus MG, van Roosmalen J, Roumen FJ, de Vries R, Wouters MG, van der Weijden T, Hermens RP.

Involving women in personalised decision-making on mode of delivery after caesarean section: the development and pilot testing of a patient decision aid.

BJOG 2014;121:202-9.

Vankan E, Schoorel EN, van Kuijk SM, Mol BJ, Nijhuis JG, Aardenburg R, Alink M, de Boer K, Delemarre FM, Dirksen CD, van Dooren IM, Franssen MT, Kaplan M, Kleiverda G, Kuppens SM, Kwee A, Langenveld J, Lim FT, Melman S, Sikkema MJ, Smits LJ, Visser H, Woiski M, Scheepers HC, Hermens RP.

Practice variation of vaginal birth after cesarean and the influence of risk factors at patient level: a retrospective cohort study.

Acta Obstet Gynecol Scand 2017;96:158-165.

Schoorel EN, van Kuijk SM, Melman S, Nijhuis JG, Smits LJ, Aardenburg R, de Boer K, Delemarre FM, van Dooren IM, Franssen MT, Kaplan M, Kleiverda G, Kuppens SM, Kwee A, Lim FT, Mol BW, Roumen FJ, Sikkema JM, Smid-Koopman E, Visser H, Woiski M, Hermens RP, Scheepers HC. Vaginal birth after a caesarean section: the development of a Western European populationbased prediction model for deliveries at term.

BJOG 2014;121:194-201.

Kessels IMH, Melman S, Neijenhuis R, Vrouenraets FJPM.

Een iatrogene oorzaak van fluxus postpartum.

NTOG 2016: 186-190.

\section{Presentations}

S Melman, J Wijma, BW Mol, J Doornbos, H Visser, G Kleiverda, J Duvekot, E Smid, M Porath, F Delamarre, FVrouenraets, S Kuppens, R Aardenburg, I van Dooren, M Franssen, F Lim, J Sikkema, P van der Salm, A Huisjes, A Kwee, C Dirksen, L Smits, J Nijhuis, H Scheepers, R Hermens.

De huidige zorg in Nederland na een voorgaande sectio caesarea: de visie van de patiënt.

(Gynaecongres 2011, oral presentation)

S Melman, J Wijma, BW Mol, J Doornbos, H Visser, G Kleiverda, J Duvekot, E Smid, M Porath, F Delamarre, F Vrouenraets, S Kuppens, R Aardenburg, I van Dooren, M Franssen, F Lim, J Sikkema, P van der Salm, A Huisjes, A Kwee, C Dirksen, L Smits, J Nijhuis, H Scheepers, R Hermens.

De huidige zorg in Nederland na een voorgaande sectio caesarea: de visie van de patiënt.

(Gynaecongres 2011, poster) 
S Melman, HCJ Scheepers, RPMG Hermens and the SIMPLE project group.

Development of indicators to determine the quality of cesarean section care.

(SMFM 2012, poster)

S Melman, HCJ Scheepers, C Dirksen, A Kwee, L Smits, JG Nijhuis, RPMG Hermens and The SIMPLE project group.

Analysis of current Dutch practice on cesarean deliveries.

(SMFM 2013, poster) 


\section{Dankwoord}

De SIMPLE studie heeft een basis gelegd voor verder wetenschappelijk onderzoek binnen de verloskunde. Dit alles is tot stand gekomen dankzij de begeleiding en steun van velen.

Prof. Dr. Nijhuis, beste Jan. Tijdens de opleiding waren je kritische blik en nadruk op de visie van de patiënt al duidelijk. Later, tijdens het promotietraject, zijn de scherpe commentaren bij onderzoeksvoorstellen en manuscripten van bepalende invloed geweest. Bedankt voor de positieve en motiverende woorden en de tijd die je hebt geïnvesteerd in de begeleiding.

Dr. H.C.J. Scheepers, beste Liesbeth. Bedankt voor de dagelijkse begeleiding van mijn promotietraject en de kans om tijdens mijn opleiding te starten met SIMPLE. Je had zeker gelijk; het is niet altijd eenvoudig om een promotietraject te combineren met een opleiding tot gynaecoloog en een gezin. Daarom ook bedankt voor je geduld en de ruimte die je me hebt gegeven. Je ideeën voor obstetrisch onderzoek en de mogelijkheden die je overal ziet lijken onuitputtelijk. Je bent een inspiratie op dit vlak.

Dr. R.P.M.G. Hermens, beste Rosella. Ik heb veel van je geleerd. We spraken elkaar meerdere malen in Nijmegen, maar ook telefonisch was je altijd beschikbaar voor overleg. Je nuchtere, reële kijk op onderzoek heeft gezorgd voor een duidelijk evenwicht. Bedankt voor alles.

Graag wil ik de leden van de SIMPLE projectgroep bedanken: prof. Dr. Carmen Dirksen, dr. Sander van Kuijk, dr. Anneke Kwee en dr. Luc Smits. Bedankt voor jullie ideeën tijdens het onderzoek en de uitgebreide feedback op de manuscripten.

Dr. N.D. Bouvy, Prof.dr. K. Bloemenkamp, Dr. J. Braspenning, Prof.dr. M.E.A. Spaanderman, Prof.dr. L.J.I. Zimmerman. Bedankt dat jullie de tijd hebben genomen dit proefschrift door te nemen en te beoordelen.

Sander van Kuijk, ik heb ontzettend veel van je geleerd. Bedankt voor je geduld en je gave om statistische analyses logisch en begrijpelijk te maken.

Ellen Schoorel, Emy Vankan en Fleur Tournois. Bedankt voor jullie ideeën, inzet en het brainstormen over de SIMPLE. Het is met vereende krachten een succesvol project geworden. Ellen, jij hebt je promotie reeds geweldig afgerond. Emy en Fleur, ik kijk uit naar jullie boekjes.

Ook de studenten die geholpen hebben bij dit project wil ik bedanken: Jannie Wijma, Rachel Schreurs en Claudie Steeman. Het was erg leuk om jullie te begeleiden, bedankt voor jullie 
bijdrage aan dit onderzoek, nieuwe inzichten en jullie humor.

Gynaecologen van het Zuyderland MC, staf Obstetrie en Gynaecologie van het MUMC+ en AIOS, bedankt voor jullie inzet, enthousiasme en humor tijdens de opleiding en daarna. Lieve collega's van de verloskamer, afdeling, poli en secretariaat in Heerlen, wat fijn dat jullie deur altijd openstaat. Niet alleen in goede tijden staan jullie klaar, maar juist ook de belangstelling en interesse in moeilijker tijden is hartverwarmend. Lieve collega's van het secretariaat van het MUMC+, wat fijn dat er altijd een plekje vrij is. Een beetje humor tussendoor maakt de dag zoveel leuker.

Frans Roumen. Bedankt voor alle tips en tricks, ze gaan altijd mee de OK op. Mercelina Roumans, bedankt voor het vertrouwen en het inzicht in patiëntenzorg in het algemeen. Josje Langenveld, mijn mentor, altijd tijd voor een gesprek over opleiding en onderzoek, maar ook op persoonlijk vlak een grote steun. Roy Kruitwagen, bedankt voor de support en visie op het vak tijdens de opleiding. Christine Willekes, je unieke visie op de opleiding, onderzoek en je persoonlijke interesse zijn bijzonder. Even sparren met jou zorgt altijd voor nieuwe ideeën en energie.

Mijn paranimfen. Imke, wat ben ik blij met alle gesprekken en slechte grappen tijdens de opleiding en dit traject. Het was erg leuk om samen te sparren over stellingen voor dit proefschrift. Kim, een zondagmiddag bij jullie op de berg is altijd goed. Alles kan besproken worden tijdens de koffie of tijdens een barbecue met een wijntje.

Lieve familie, vrienden en vriendinnen. Bedankt voor alle gesprekken, hulp, oppas, gezellige avonden en weekenden - dit heeft me de afgelopen jaren ontzettend geholpen. Zonder jullie energie was dit niet gelukt.

Collega sporters bij Kimbria, een top team en top club om bij te horen.

Lieve schoonfamilie, Angela, JW, Loes, bedankt voor alle gezelligheid en de welkome afleiding in de Achterhoek. Ik kijk uit naar de volgende familiedag!

Lieve pap en mam, jullie steun, positieve instelling en belangstelling hebben me geholpen tot dit punt te komen. Via biomedische wetenschappen en geneeskunde in Leiden naar gynaecologie in Maastricht. Jullie staan altijd voor me klaar. Dank jullie wel voor alles.

Wouter en Yvonne, broertje en schoonzus, bedankt voor de verhelderende gesprekken, humor en de gezellige avondjes (liefst met kampvuur). We hebben altijd bitterballen voor jullie in huis! 
We hebben een bijzondere en intense tijd achter ons, Robin. Je had oneindig vertrouwen in me en wist me altijd weer te motiveren. Je bracht een andere kijk op de wereld. Meike en Nathan, jullie staan altijd klaar met een gevatte opmerking of een glimlach. Jullie nuchtere kijk op de wereld zorgt ervoor dat ik met twee benen op de grond blijft staan. Lieve Michel, ik geniet van een nieuwe kijk op de toekomst die je hebt gebracht. De gesprekken met jou, jouw liefde en een knuffel maken mijn dag weer goed. 


\section{Curriculum Vitae}

Sonja Melman werd geboren op 30 maart 1979 in Spijkenisse. Het VWO diploma behaalde zij in 1997 aan de christelijke scholengemeenschap Blaise Pascal te Spijkenisse. In datzelfde jaar startte zij de opleiding Biomedische wetenschappen aan de Universiteit Leiden. Na een wetenschappelijke stage bij Eurotransplant rondde zij deze studie succesvol af in 2002. Daarnaast startte zij in 2000 met de studie Geneeskunde aan de Universiteit Leiden. Na het behalen van het artsexamen in 2005 werkte zij als arts niet in opleiding tot medisch specialist (ANIOS) verloskunde en gynaecologie in het Reinier de Graaf Gasthuis in Delft (2005-2007) en het Maastricht Universitair Medisch Centrum+ (2007-2008). In 2008 startte zij de opleiding tot gynaecoloog, waarbij zij zowel in het MUMC+ (opleider: Prof. Dr. R.F.P.M. Kruitwagen, plaatsvervangend opleider: Dr. G.A.J. Dunselman) als in het Atrium Medisch Centrum (opleider: dr. P.E.A.M. Mercelina, plaatsvervangend opleider: F.J.M.E. Roumen) werkzaam was. Tijdens de opleiding startte zij met de SIMPLE studie zoals beschreven in dit manuscript. De specialisatie Obstetrie en Gynaecologie rondde zij af in 2016, waarna zij werkzaam was in het Zuyderland Medisch Centrum en MUMC+. Zij is momenteel werkzaam bij de Parkwegkliniek in Maastricht. Haar hobby's zijn koken, reizen en basketbal samen met haar gezin: Michel, Meike en Nathan. 
